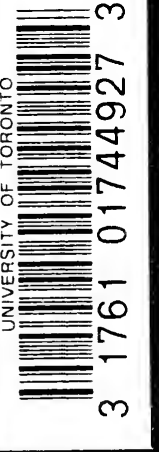




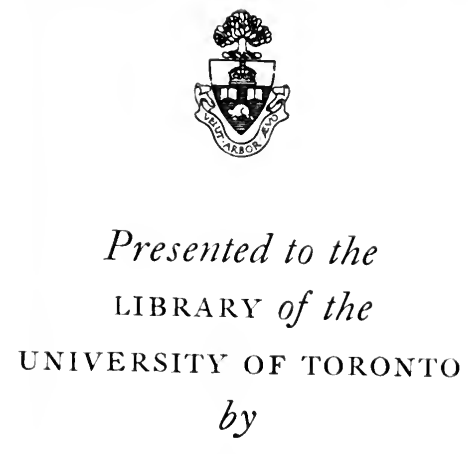

MRS. FRED WADF, 
oppis 
Digitized by the Internet Archive in 2007 with funding from Microsoft Corporation 


\section{RECONSTRUCTION \\ AND NATIONAL LIFE}




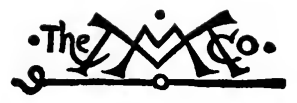

THE MACMILLAN COMPANY SEW YORK - BOSTON - CHICAGO - DALLAS ATLANTA - SAN FRANCISCO

MACMILLAN \& CO., Limited

LONDON - BOMBAY - CALCUTTA MELBOURNE

THE MaCMILlaN CO. OF CANADA, LTD. TORONTO 


\title{
RECONSTRUCTION AND NATIONAL LIFE
}

\author{
BY \\ CECIL FAIRFIELD LAVELL, Ph.D. \\ (COLUMBia) \\ Associate Professor of History, Grinnell College
}

Jew 单ork

THE MACMILLAN COMPANY

1919

$4 l l$ rights reserved 
COPYright, 1919

BY THE MACMILLAN COMPANY

Bet up and electrotyper. Published, April, 1919

$$
\begin{aligned}
& D_{63} \\
& L_{3}
\end{aligned}
$$

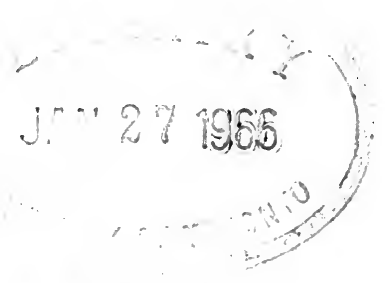

104469 


\section{FOREWORD}

Reconstruction is not, to an American, a word of the happiest associations. To even a superficial student of American history it means one episode and one only, an episode to which no southerner can yet refer without heightened color, no northerner without discomfort. But we do not recall such a memory to promote pessimism - only to remind ourselves that it was reconstruction of the South by the North that failed and that proved more destructive than the war itself. The reconstruction that succeeded was undertaken by the South and was carried through in spite of all handicaps. And the reminder may help us to estimate the permanent and the passing, the fundamental and the external in the Europe of 1919. For it may be that some of us watch too exclusively the labors of the Congress at Paris and ignore the pathetic and powerful struggles of the people of Europe for security, freedom and self-realization.

The problem of reconstruction may be approached from two angles. One phase of it is necessarily somewhat formal and external. Wounds have to be healed, 
deformities have to be removed, frontiers have to be redrawn along national lines, rival claims have to be considered where nationality is mixed or doubtful, new states that were formerly parts of the German, Austro-Hungarian or Russian Empires have to be delimited and recognized, and form must be given to the League of Nations. The other phase is even more complex and fundamental. It involves the renewal of normal lines of life and progress by all the nations involved in the war, the picking up of strained and broken threads, the reconsideration by each people of its own problems after the tremendous crisis that is now past.

The formal, diplomatic phase is the one that primarily concerns the Peace Congress at Versailles. Its difficulties are in theory not particularly formidable, for the most part, for the settlement must proceed on principles universally admitted. The practical difficulties, on the other hand, are enormous, and can be removed only by a minute knowledge of the facts and by infinite tact. But however carefully we may endeavor to follow and understand this external side of reconstruction we are in the main powerless to aid or hinder. All we can do is to clarify the issues in our minds and try to grasp the most essential facts.

The more subtle and far-reaching phase of recon- 
struction is that implied in self-determination, the problem imposed on each people of facing its own issues, reconsidering its own aims and lines of advance. In this we cannot always give mutual aid in a direct and material way, but we can aid in sympathy and un'derstanding. And if this kind of aid, intangible, spiritual, immensely powerful, is to be rendered intelligently we must above all things try to know the character and the problems of the peoples with whom we are to be associated in our League of Nations. For whatever form the League may take and however that League may be modified in the years to come it will stand or fall not mainly through formal merits or formal weaknesses but through the degree to which it succeeds in " organizing the friendship of the world."

It is this latter phase of reconstruction that I have had chiefly in mind in the chapters that follow. They rest on the conviction that important as the formal work of the Peace Congress may be there is a more fundamental and permanent work of reconstruction that must fall on each nation, not a reconstruction that will be built on the deceptively tangible foundation of maps and treaties but a reconstruction built on the hopes, the convictions, the struggles, the dreams of the peoples. The basis of such reconstruction is not to be found in documents or institutions, for it is a living 
and dynamic basis, and the structure will not be one that may be completed in a year; its foundations have been shaping for centuries, and none of us will live to see the work receive its final touch. But in the meantime we may aid in the building by knowledge, sympathy and good-will. And our first step must be the study of the foundations on which the anxious and wearied peoples of Europe are to build, the solid and yet ever changing foundations of human life in its struggle toward a social ideal.

Of the need for such a study we are earnestly convinced. For the isolation of the United States is broken, and apparently broken forever. The Atlantic has been bridged, or rather it has become to America what the Channel has been to England for a thousand years. It still separates us from Europe, but we no longer have the illusion that the troubles of Europe are the troubles of another planet. It was always an illusion. There was never a time when the affairs of peoples so closely akin to us in blood, in traditions and in thought did not matter to us. Not only has the stream of immigration never stopped, not only have all of us friends or relatives who were born in Britain, Germany, France, Italy, Russia and the remotest corners of the older world, but our reading and thinking of every day brings us into touch with the lands and 
peoples across the sea. We were all really aware of this before the war. But the old condescension of Europe toward America had been replaced by a more arrogant condescension of America toward Europe. and we assumed an attitude of lofty remoteness, an attitude born of conviction both of security and of superiority. That attitude, we may hope, is gone forever. And now it is necessary to turn with frank inquiry and with sympathy to the effort to understand our overseas kindred whose tragedies we have in some measure made our own. It is not enough to have American representatives in the Peace Congress or to send Commissions. Each of us must try to clear away the fog of ignorance and prejudice that blinds our eyes, and to understand the problems that Europe has been facing in past years and is facing still. For we at last see that those problems are our own, and that in the burden of their solution we must bear our share.

To this effort toward the understanding of the living basis of Europe's problem of reconstruction I have contributed only an introductory survey, hardly more indeed than the statement and illustration of a point of view. To this end the scope of the book has been limited, except for the first chapter, to the study of four peoples, the French, the German, the Russian, and the British. A bibliography has seemed hardly 
necessary, but the student will find it advisable to have within reach any good history of modern Europe, such as Hayes, Political and Social History of Modern Europe (Macmillan, I9I7), or Schapiro, Modern and Contemporary European History (Houghton Mifflin, 1918). And he will find constant stimulus and help in Arnold Toynbee's two books, Nationality and the War and The New Europe (Dent, London, and E. P. Dutton, New York, I9I5-6).

C. F. L.

Grinnell, Iowa, March IO, I9I9. 


\section{CONTENTS}

CHAPTER

PAGE

FOREWORD • • • • • • • • • • •

I The Problem: Europe's Unsettled Questions I

II Revolution and Readjustment in France • • I7

III The French Revolution and National Life • 37

IV The Basis of Reconstruction in Germany $\quad 56$

$\mathrm{V}$ Inealism in German Politics . . . . . 74

VI The Russians and the Dawn of Russian FreeDOM • • • • • • • • • • • • • 92

VII The Russian Problem and the Revolution • II4

VIII British Liberty and the EMPIRE • • • • . I4I

IX The New Idealism in England . • • . . I65

AfTERWORD: NATIONALISM AND INTERNATIONAL-

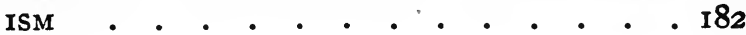





\title{
RECONSTRUCTION AND NATIONAL LIFE
}

\author{
I \\ The Problem: Europe's Unsettled
}

Questions.

THE student who is seeking for some basis for the reconstruction of Europe in the history of the nineteenth century will find the grouping of his facts controlled mainly by four great phenomena - the growth of nationality, the growth of democracy, the expansion of Europe, and the industrial revolution. None of these, with the exception of the last, were of recent origin. The expansion of Europe began four hundred years ago with Columbus and Vasco da Gama, and before the end of the eighteenth century North and South America were already committed to the domination of peoples of European stock, the British were masters of a large part of India, and the Russian Empire reached a long arm across Siberia to the $\mathrm{Pa}$ cific. Similarly, nationality and democracy are not 
new ideas: Swiss, Dutch, and English patriots fought for their country centuries ago, and both national feeling and the idea of government by the people go back at leasi as far as Marathon and the Athenian demos.

But the nineteenth century saw "imperialism" assume a new and tremendous significance with the completion of the British conquest of India, the Russian advance into central Asia, the colonization of Australasia, the partition of Africa, and the rapid rise of the overseas dominions to wealth and power. At the same time nationality and democracy have come to have a force and significance in the world since the French Revolution that they had never had before; nations have moved toward self-consciousness and freedom on a mighty and unprecedented scale until they have quite displaced the monarchs of a century ago in the sovereignty of Europe. And the industrial revolution is quite narrowly and definitely modern. It began in the eighteenth century, and since James Watt drew out his first patent in 1769 mechanical science, steam and electricity have changed the face of the world.

All of these phenomena have brought with them potent forces of change and upheaval. With them have come new visions, new aspirations and fierce enthusiasms. On the whole, no doubt, they have worked good rather than evil, but the one certainty is that they 
have wrought havoc with old standards and old traditions, that they made possible the great war, and that they will quite largely dominate the process of reconstruction. Moreover - and the understanding of this is fundamental - they have nothing like reached completion. For an old social and political system dies slowly, and if it is true in a sense that the world is in a perpetual process of death and re-birth there are some periods - and the nineteenth century was one of them - when the process is peculiarly far-reaching and convulsive; the old stubbornly resisting dissolution, the new persistently asserting its claims. When the twentieth century opened it saw the states of Europe still imperfectly adjusted to any of the new ideas that were every year growing more insistent, more certain of ultimate victory. Nationality partly coincided with state frontiers - but not wholly. The peoples were steadily moving toward control of their governments, but they were still far from the goal of a democratic Europe. Expansion had brought power, wealth, a widened horizon, and had brought also formidable problems of government, terrible possibilities of jealousy, rivalry and arrogance. The industrial revolution had given the world incredible increase in production, miraculous means of communication and transportation, with the factory system, the centralization of industry, the conflict between labor and capital, 
the appearance of anarchism and socialism. The old régime was dying, perhaps, but it was not dead, and it clung obstinately to life. The new régime was fast learning and asserting its powers, but its victory was not yet final and its constructive aims were undetermined, still in controversy.

For the widespread and growing conviction that the future belonged to the peoples, not to kings, nobles, aristocracies, was far from settling the question. "People" is a vague word. It by no means stood for a clear and homogeneous fact. The victory of nationality and democracy was postponed while classes and sections wrangled over details. The political liberty that was almost won was declared to be valueless without economic liberty. And the millions of men and women between the Atlantic Ocean and the Ural Hills seethed in uneasy life, unsure of their desires and their powers, sure only of a light that might dazzle but was still a light, a freedom that might bewilder and intoxicate but was still freedom, an ideal that might have a tantalizing way of assuming a myriad changing forms, but yet held the promise of a golden age.

I. Let us consider the force of nationality first. In the course of the nineteenth century Italy and Germany, from being " geographical expressions" became 
united and highly conscious states, inspired by a national feeling that was quite new, that had been nonexistent when the French Revolution began, but that was fervent and apparently deep-seated. France had had many of the elements of national life under the Bourbon kings, but they were fused by the Revolution into a sentiment of new and tremendous power. England, Scotland, Wales and - more doubtfully - Ireland, in their slowly cementing partnership, felt no sudden change, but even British nationality acquired a fresh vigor and clearness of conviction, and the spread of national consciousness through the British dominions overseas meant a significant widening of the whole idea as the same imperial patriotism showed itself in Melbourne, Winnipeg, Auckland and Cape Town. To Italy, Germany, France and the British Empire we may add all of the smaller states of Europe, not least those that had broken loose from the Turkish Empire only a few generations ago. In all, the theory of nationality, vague and sometimes ill-defined as it might be, was held with conviction; in all, state and nation, political and national boundaries, were supposed to coincide.

But this theory by no means corresponded with fact. Russia and Austro-Hungary were the most conspicuous cases in point. Within their boundaries there was 
national sentiment, but it was divided and had little relation to government or boundaries. And even within the limits of the countries most strongly moved and controlled by the national spirit there were inconsistencies and diverse elements that boded trouble. Italy felt that she was incomplete without the Trentino. France after I87 I mourned the loss of AlsaceLorraine, Denmark the loss of Danish Schleswig. Within the German Empire were Poles, Danes and Frenchmen who passionately resented their inclusion in a political unit with which they felt no national bond. Even Great Britain had discomfort in the problem of Ireland. And the Balkan states surveyed their arrangement on the map with an indignant sense that their bounds had been set with no regard whatever to nationality, that the whole peninsula would have to be re-divided before they could be at rest.

From the point of view of nationality, then, we can easily distinguish on the map of Europe certain "sore points," as it were - centers of unrest that might or might not provoke wars but certainly merited consideration and would threaten the world's peace until they were settled. They were all relics of the old diplomacy. The Trentino had "belonged" to Austria long before Italian unity was dreamed of, and it remained unredeemed. Poland had been divided to 
suit the convenience of Austria, Prussia and Russia, the consideration of nationality entering not at all into the calculations of the rulers who effected the partition. Alsace-Lorraine and Schleswig were annexed to the German Empire for state reasons and by military force. Ireland had been conquered by England ages ago, had been semi-anglicized, and now proved difficult of national assimilation even when given freedom and full partnership. And the Balkan problems were problems resulting from work half done by the diplomats of the Great Powers, from the sullen restiveness of nations half given national existence and grudgingly left incomplete. There was an unredeemed Serbia in the Austrian province of Bosnia, an unredeemed Roumania in the Austrian province of Transylvania and in the Russian province of Bessarabia, an unredeemed Greece and Bulgaria in Macedonia, just as there was an unredeemed France, an unredeemed Denmark, an unredeemed Italy, an unredeemed Poland. And all of these meant restlessness, agitation, bitterness, the threat of war.

2. The incomplete realization of democracy was a menace second only to that springing from incomplete or thwarted nationality. Here Britain (including Ireland, of course, for the Irish have for years been as free as the English or the Scotch), France, Italy, Hol- 
land, Belgium, Switzerland, the Scandinavian and the Balkan states may be left out of consideration. Not all had achieved complete democracy, but democracy was steadily moving toward realization with the goal in sight and no considerable obstacles in the way. As far as freedom and self-government were concerned these states presented no problem that could not be settled in peace and without bitterness. But putting aside what was left of European Turkey - a recognized anomaly that could be removed in only one way and that way quite inevitable - there were Russia, the German Empire and Austro-Hungary, powerful states in which the people were denied control of the government. In Germany and Austro-Hungary there were popular elements in more or less adequate representative assemblies, but in both empires a small governing class really controlled all the effective machinery of state. In Russia the essential principle of government was autocratic, working through a powerful bureaucracy. The result was that in all three there was an active and growing revolutionary element, and observers in other countries felt that the ultimate victory of the revolution in central and eastern Europe was not only a mere matter of time but might well mean a civil conflict and a shock to the world. It might be a necessary and healthful shock, but a rad- 
ical change in the constitution of three great empires was a thing not to be contemplated without anxiety - just as even a necessary surgical operation may involve shock, suffering, and the chance of disaster.

3. The question of expansion takes us beyond the geographical bounds of Europe, but we may warrantably consider it in its reaction on the parent continent. The conflict between expanding empires has been a familiar danger for ages. Even in modern times it is a common observation that the series of wars between France and England, the second Hundred Years' War as Seeley called it, from I689 to I8I5, became a duel for empire, with mastery in America and India as the prize of the victor. The wars of I854-6 and of I877-8 were due to Russia's expansion towards Constantinople; the nervous tension between Russia and Britain during the latter half of the nineteenth century was due to anticipated conflict in Asia; the war between Russia and Japan in 1904-5 was directly due to expansion and collision; and the series of crises that culminated in the outbreak of war in I9I4 largely turned on rival ambitions and jealousies in the Balkans, Asia and North Africa. At the opening of the twentieth century peoples of European stock so largely controlled the rest of the world that further expansion almost inevitably meant war. The British 
flag flew over all of Australia, all of India, half of North America, a large part of south and central Africa, and islands and coasts beyond number. France was the mistress of Madagascar, Siam, and a huge dependency in north-west Africa. Latin-American republics held all of south and central America, their independence jealously guarded by the United States. The United States of America had not only become the greatest power in the world outside of Europe but had extended American influence across the Pacific. Russia dominated north and central Asia.

It is hardly necessary to point out the grave and complex problems involved in imperialism. But except for two of the European states it did not seem likely in I9I4 that these problems need disturb the peace of the world in the immediate future. The ancient rivalry between England and France was ended by the understanding reached in 1904. The more recent rivalry between England and Russia was settled, apparently, by the treaty of 1907 . There were still dangers in the situation, but the only actual and impending menace came from the ambitions of Germany and Italy.

Germany had secured in the scramble of the eighties only three sections of Africa, large in area but of doubtful value, and she held also a few islands that were of little importance without further acquisitions. 
To erect a German colonial empire at all commensurate with Germany's position in Europe would be possible only through war and conquest, unless indeed western Asia might be relieved from Turkish rule, developed, and ultimately annexed. So the hope embodied in the Drang nach Osten became a cardinal factor in German politics, more evident with each year of the new century. But it involved the crossing of the Balkan peninsula, and this meant a threat against the independent nationality of the Balkan states and an almost inevitable conflict with Russia. The south-western push of Russia, the south-eastern push of Germany intersected.

Second only to this in danger were the ambitions of Italy to control the Adriatic and to acquire part of North Africa. Her wrath at the French annexation of Tunis in I88r had thrown her into the Triple Alliance with Austro-Hungary and Germany. Her disastrous adventure in Abyssinia, ( 1896 ) only persuaded her to look for colonies nearer home. Her conquest of Tripoli in I9I I-2 was a dangerous portent. And her ambition to make the Adriatic an Italian lake was an immediate menace to Austro-Hungary and a potential menace to Serbia. Here was a knot that might well call for the sword. And now that the sword has struck and has been returned to its sheath the knot is seen to be only partly cut. Even the collapse of the 
Austro-Hungarian Empire has not solved the problem of Trieste, and there still remain the rival claims of Italy, and the new Jugo-Slav state across the sea. Italy's dreams of expansion eastward would seem to be inconsistent with the national hopes of the Slavs of Serbia, Bosnia and Croatia.

4. The industrial revolution had created a condition that might or might not issue in war indeed, but that might and did issue in political and social disturbances of the first magnitude. The effects of the change in production and distribution would alone have been enormous even if they had come about by some simple magic of science without the rise of factories and factory towns. But the factory system had meant first the oppression and degradation of the laborer, then combination in unions, the gradual development of a social intelligence among the laborers, and the appearance of a state of affairs in which the relation between capitalists and laborers became one of armed neutrality, war, or peace based on treaties.

Finally, as the world struggled to adjust itself to the situation, there appeared at least two new phenomena which still exist and are still in process. One is the extension of capitalism among the laborers themselves. The other is the appearance of a variety of social gospels among which that which goes under the vaguely understood word "socialism" is, no doubt pre-emi- 
nent. Fifty years ago socialism was sufficiently powerful to attract the thunderbolts of Bismarck. But they were launched in vain. The new program of economic and social upheaval waxed stronger under both persecution and the scorn of the elect, until now socialism has definitely appeared in international politics. It is dominant, temporarily at any rate, in Germany and in Russia, and whether or not it retains its present forms it represents a force which cannot be ignored. Like incomplete and thwarted nationality, like incomplete and thwarted democracy, like the conflict of expanding empires, the vigorous agitation of the classes hitherto without power in national direction, their demand for a more perfect economic organization of society, represents one of the world's unsettled problems.

But partly arising from nationality, democracy, expansion, and the industrial revolution, and partly springing from less tangible sources and currents, - there is a movement of which socialism is only one phase, and that not necessarily the most important. It is a movement which will not formally appear, perhaps, in any diplomatic discussion nor be given a place in any treaty. And yet one who is studying the basis of reconstruction cannot ignore it. We might define it briefly, adapting Michelet's famous definition of the Renaissance (" the discovery of man, the discovery of 
the world") as man's discovery of humanity. And if this sounds vague and rhetorical it is because the - movement itself has a vagueness and a tremendous potency that defies exact definition. How are we to define the spectacle of the human mind breaking its ancient bonds, questioning all things and overleaping all barriers, the human soul reaching out to others and discovering kinship, the human spirit with new vision and new power breaking the chains of ignorance, destroying the dividing walls of class and prejudice, holding up the ideal of liberty, equality and brotherhood, seeing new meaning in the command $B e$ ye therefore perfect. At the close of the most terrible war recorded in human annals, with a great part of the world writhing in still unrelieved agony, we can yet feel that Armageddon was the tempestuous announcement of the adolescence, let us say, of a new age, whose birth was proclaimed with the Social Contract and the French Revolution. It was the conflict of forces that have been taking shape for a hundred years and more. And it had hardly begun when dreams and aspirations once vague and clouded - revealed only to the few became clearer and more insistent for realization.

On the surface and in its inception the issues of the war were political - the ambitions of a state intoxi- $s$ cated with power, the rivalry of Pan-germanism and 
Pan-slavism, the conflict of democracy with autocratic or aristocratic militarism. And these issues were great and fateful, not in any sense to be ignored. Yet before the German armies had been in Belgium a day, certainly long before Verdun or the Somme, we were aware that there were moral and spiritual issues vastly greater than any question of control of the Balkans, the possession of Alsace-Lorraine, or even popular versus autocratic government. And as the struggle went on the directly political issues, important as they were, appeared relatively less and less so. Even the Revolution in Russia, apparently a purely political phenomenon, soon turned out to be political mainly in a negative sense. For it was not constructive in the ordinary sense at all; it was an upheaval of moral and spiritual forces that were sweeping aside an outworn form. The original causes of the war were almost forgotten as the new issues leaped into view, dazzling and bewildering, new and yet not new, familiar and yet smiting us with the shock of sudden and vivid comprehension. Even the dramatic collapse of the two Central Empires stirred our imagination but sluggishly, so convinced were we that Hohenzollerns and Hapsburgs had been stage heroes, dressed in trumpery and out-of-date splendor - that the life and spirit of their drama had vanished before the fall of the cur- 
tain, the last scenes played before a cold and disillusioned audience.

Part of our task then will be to trace the source of Europe's troubles in the thwarted development of nationality and democracy, in the mixture of good and evil in expansion, in the class conflicts and social upheavals that have come from the working out of the industrial revolution. But we must never lose sight of the fact that these do not cover the whole field. Behind them, driving them and often molding them, is the less concrete but none the less dynamic movement toward spiritual emancipation. 


\section{II}

\section{Revolution and Readjustment in France}

ThE French Revolution began, our historians tell us, with the meeting of the States General ${ }^{1}$ in May, I789, or with the storming of the Bastille by the Paris mob in the following July, or with the abolition of feudal privileges in August. And it is commonly considered to have closed with the beginning of Napoleon's mastery in I799 or perhaps with the final collapse of his power in I8I5. These dates have the advantage of definiteness and convenience. But we must not let them obscure the real facts. Dates are landmarks, quite indispensable for clear historical thinking; but when we use them to mark off periods they are never more than approximate, and to allow them to dominate our minds is much worse than to ignore them entirely. The events of 1789 were of great importance and are

1 States General is the name given to the body which was the French equivalent of the English Parliament. It represented three classes or estates - the first estate, the clergy, the second, the nobles, and the third, the Commons or towns-people. The States General met first in 1302 , seven years after the birth of the English Parliament in I295. But it had a less happy history, and its last meeting before 1789 was in 16r4. From r6r4 to 1789 the king was an autocrat. 
worth remembering with all possible exactness. They represent the visible end of the old Bourbon régime. But in its real significance to France and to Europe the Revolution is as difficult to date exactly as, say, the Renaissance, or what we call the Middle Ages, or the Reformation. It began long before 1789 and ended - it may be - about a century later. Indeed some have suggested not inaptly that it ended with the Marne and Verdun. And we shall even see reasons for believing that it is still in process, that France's problem of reconstruction is really best understood as a phase of the Revolution. For the Revolution represented not merely a political change from absolutism to democracy but a changed way_of looking at life, a social and spiritual movement, vague perhaps as to exact dates but by no means vague in its essential character or in its results.

The fact remains that conventional dates have their value in giving us a kind of skeletal structure, and there are a few that we shall assume in our discussion. Let us fix in our minds the publication of Rousseau's Social Contract in 1761 and his Emile in 1762 , the meeting of the States General in 1789, the proclamation of the first French Republic in I792, the attainment of supreme power by Napoleon Bonaparte in I799-I804, his fall and the restoration of the Bourbons in $18 I_{5}$, the expulsion of Charles $\mathrm{X}$ and the ex- 
periment of an elective king, Louis Philippe, in I830, his removal and the proclamation of the Second Republic in 1848, the Second Empire - that of $\mathrm{Na}$ poleon III - from 1852 and 1870 , and the beginning of the Third Republic in September, 1870, after the defeat at Sedan. Beneath the surface, beneath these securely dated political facts and giving them meaning, was the spirit of the Revolution, the spirit that moved France from the mid-eighteenth century to the present day. It is only by understanding this spirit, the motive force that gave the Revolution its power to destroy and rebuild, that we can see the meaning and drift of the gropings, the discouragements, the mighty enthusiasms, the failures and the successes of a great people in a great era.

What then was in the minds of the representatives of the French towns as they took their seats in the great hall at Versailles on the fifth of May, I789? What questions and what ideals were stirring them, what education had equipped them for the task that lay before them, what leaders and forces had molded them? Only in small degree can we answer this, but we can very easily see the essential facts that they faced and the most controlling ideals that ruled them. The most obvious of the facts was the appalling political crisis that had caused the government, sorely against its wish, to call them together; the most obvious of the 
ideals was that voiced by Jean Jacques Rousseau; and the minds of the Deputies, as of most thinking Frenchmen, moved along channels largely made for them by Montesquieu, the Encyclopædists and Voltaire.

Every member of the States General knew that the actual government of France was a ghastly failure. They knew that the previous century had seen the development of an absolute monarchy which had at least had the merit of brilliant success. Under Henry IV, under the ministers of Louis XIII - Richelieu and Mazarin - and under Louis XIV and his advisers, notably Jean Baptiste Colbert, France had become the first state of Europe, first in military power, in industry, in commerce, in literature, and in military and æsthetic leadership. Freedom was indeed sadly curtailed, and there were many abuses. But if France was governed by an autocracy it was at least an efficient one, and if the merchants, the craftsmen, the professional men, even the land-holding aristocrats, were allowed no share in legislation or administration they at least waxed prosperous and grew in mental keenness, in breadth of vision, in spiritual courage and initiative. Then came the later days of Louis XIV, when the giants were dead and when defeat and disaster humbled the pride of France. Then came year after year of futile government when a people intelligent and quick beyond most others, a people trained to know 
efficient leadership when they saw it, learned to despise their rulers and to chafe at neglected abuses. When at last national bankruptcy threatened, and the government of Louis XVI was forced to summon the States General, every man who came to Versailles knew the record, knew the story of the great days of Henry IV, Richelieu and Colbert, of the evil days of Louis XV and Louis XVI. The monarchy was weighed in the balance and found wanting. The glitter of the court of Louis XIV had concealed the false principles on which it was based. Now the glitter was gone, and the rotten foundations stood out in melancholy clearness. ${ }^{1}$

Moreover, they all knew that while the political machinery had been groaning and creaking toward dismal collapse the people, powerless in government, had shown no signs of decadence or apathy. Keen thinkers and prophetic geniuses had entered eagerly on the inquiry into natural laws, the basis of government, the principles of economics, the foundations of religion, all the phenomena of nature and society. Everywhere

1 The student who wishes to have a brief first-hand statement of the abuses and tyrannies that were to be swept away in the Revolution may find it in the Protest of the Cour des Aides presented to the king in 1775 , fourteen years before the meeting of the States General. It is published in English in the University of Pennsylvania Translations and Reprints (Longmans, Green and Company). 
men were investigating and discussing the reason of things. Every thinking man in France knew of the work of Diderot and his companions of the Encyclopædia. Every man who could read, i. e., the great mass of those who guided public opinion in the towns, had read the tracts of Voltaire, the Social Contract and the Emile of Rousseau. Every man who stood in outward deference before the king in May, I789, had learned to ask the question "why?", had laughed, albeit grimly, at the literary cartoons of the great mocker, and had meditated wistfully on the potent dreams of a " return to nature."

Voltaire ( 1694-I778) was the first literary figure of his age. And he was far from being merely a high priest of the learned and cultivated classes. His biting humor, his penetrating and cutting criticisms, his indiscriminate attacks on church, government, and conventions of all kinds, his wit and his incomparable lucidity, gave him fame and a power to which there is no modern parallel. The general tendency of European thought in his day was toward what has been called rationalism, the fearless application of human reason to all fields of thought and belief. Religious skepticism was a fashion among polite circles in France as it was in England and Germany. But Voltaire made rationalism and skepticism popular, and his pen threatened to destroy whatever it touched. Often 
he was unfair. Often he was superficial. But he was never dull and he was always destructive. Yet he was neither a democrat nor an atheist. He despised the dreams and the inarticulate aspirations of the people as much as he despised royalty and aristocracy. He built a church ("Erected to God by Voltaire") and avowed that without belief in God morality and society itself would perish. One of his most characteristic and famous aphorisms was that if there were no God it would be necessary to invent Him. He attacked the State because it was futile, tyrannical and inefficient, not because he wished the rule of a democracy. And he attacked the Church because it was irreligious, artificial and immoral, because in the name of truth it tried to chain men's souls with superstition and dogmatism, not because he was an enemy of religion. But whatever were his personal beliefs his influence was purely destructive. Wherever his writings were read the monarchy and the church were stripped of their sacredness and held up to ridicule.

Rousseau (I7I2-I778) was of another type. If he helped to destroy the institutions and ideas of his time it was only as one destroys darkness by lighting a lamp. He was the apostle of a new idea, the idea of a return to nature. Voltaire had attacked the existing government as a modern cartoonist does, by criticizing and ridiculing specific acts and methods of tyranny and 
abuse. Rousseau concerned himself not at all with details, but struck at the root of the whole system by declaring that men were by nature free. "Man was born free, and he is everywhere in chains," is the first sentence of the Social Contract. Long ago, he said, men were absolutely free; there was no law; each did what was right in his own eyes. But they tired of this life of confusion and conflict and agreed to form a society. They devised different forms of government, giving up for the moment their right to do as they pleased for the sake of the benefits of coöperation and peace. So far this was good. But the governments managed to make the people forget their ancient liberty, and the people - not realizing that their right to life, liberty and the pursuit of happiness was inalienable - became slaves. All because they had forgotten that the powers of the government were based on a social contract and on nothing else. If one party to a contract breaks it the contract becomes void. "You are in chains," cried Rousseau. "But the chains are of your own making; your liberty is inalienable; your rulers rule only because your fathers delegated the right to sovereignty, and if they abuse their delegated power they cease to deserve it. Reclaim your liberty! Your chains are chains of straw, and if you will they will vanish at a breath."

Not that Rousseau wished to return to the anarchi- 
cal state of nature. Like the English thinkers, John Locke and Thomas Hobbes, he simply used the familiar "state of nature" hypothesis as an historical startingpoint, a false one as far as historical accuracy was concerned, but convenient for purposes of argument. $\mathrm{He}$ had no quarrel with the social contract by which he assumes men to have escaped from anarchy. But he asserted that the purpose of the contract had not been attained because the general will of the people had been supplanted by an artificial and unjustified rule of the few. Society must go through a regeneration in order to realize the purpose for which it came into being. The problem was first to break the meaningless and baseless tyranny of the existing State, and then " to find a form of association which shall defend and protect, with the entire common force, the person and the goods of each associate, and by which, each uniting himself to all, may nevertheless obey only himself, and remain as free as before." 1 So that he was not in any sense an anarchist; nor was he in the present sense of the term a socialist; he was rather stating the problem and ideal of popular sovereignty.

Rousseau's details of application were of little or no value. The magic of his gospel was in his statement of an ideal of ordered liberty. And he carefully guarded himself against the charge of lawlessness.

1 Social Contract, bk. I, ch. 6. 
Law is to him as fundamental as liberty; both are "natural" and neither is complete unless it is correlated with the other. Indeed through law liberty itself must be made compulsory. Thus he asserted a paradox which puts in a nutshell one of the most vital problems of the present hour. "In order that the social pact may not be a vain formula, it tacitly includes the covenant, which alone can confer binding force on the others, that whoever shall refuse to obey

- the general will shall be constrained to do so by the whole body, which means nothing else than that he will be forced to be free." 1 It is a dictum that might have been aptly used as a preamble to the constitution of the League of Nations.

As man is born free so he is born good. And just as he is everywhere in chains so he is everywhere brutalized by the warping and smothering network of convention that we call civilization. The program of political emancipation was set forth in the Social Contract, the program of intellectual and spiritual emancipation in the Emile. The book is the imaginary biography of a boy educated in a natural way. Instead of being repressed, molded, fed with information that he loathed, drilled in habits that had no meaning, trained not to be a man but to be a doll destined to play with

${ }^{1}$ See the whole discussion of this in the Social Contract, bk. I, chs. 7 and 8. 
other dolls in an artificial world, Emile is tended as a precious plant is tended by a skilled gardener. To cultivate a perfect rose one does not try to add to it the qualities of a tulip or a lily, nor does one use the brush to give a better color. What is needed is adequate soil, water and sunlight, protection against enemies and accidents, such additional nutriment about the roots as a healthy rose craves, and nature will do the rest. The seed is as God made it. The environment that will give the best growth is to be dictated not by the gardener but by the needs of the plant. His office is to search for laws over which he has no control, which he may not defy or neglect without harm, and which it is his sole business to ascertain and obey. Absolutely the same principle is observed with Emile. If in the course of his growth the boy should demand Latin, Greek or Mathematics to satisfy his curiosity then Latin, Greek or Mathematics become living and needed things to him, but not otherwise should he be required to learn them. Let him grow in his own way. Give him food, air, and sunlight; allow him the full and free exercise of his normal activities; protect him against danger; let his growth be the progressive satisfaction of his own craving; and if the result should make him unfit for membership in society so much the worse for society. If Emile does not become an accomplished Parisian then change Paris; do not force 
a child of God to become an artificial manikin. These then were the things that were uppermost in the minds of the men who began and carried through the demolition and attempted rebuilding of the French state in and after 1789 - on the one hand the futility and evils of the traditional system of government, on the other hand the growing spirit of scientific investigation, the impatient ridicule of shams and outworn conventions, the gospel of nature. Now what was the outcome? The idealists of I789-I793 dreamed of a golden age; the great sweeping of old abuses into a scrap heap by the successive assemblies of those years was to be the prelude to a glorious and permanent reconstruction. But the hope faded as the years went by, bringing reforms, victories, the re-vitalizing of national life and great glory - but no golden age. Napoleon appeared, was acclaimed as leader, and fell before the armies of Europe after exhausting France in fruitless wars. The Bourbon kings were restored with a constitution, it is true, and a representative assembly - but were discarded again in 1830 to make way for a "citizen king," Louis Philippe. The experiment of an elective monarchy was a mere makeshift and it lasted a short eighteen years; the republic of 1848 , the next experiment, found no leaders, was torn by party conflicts, and died with small protest or 
mourning when Louis Napoleon consummated the coup d'état that made him Emperor; and when the Empire fell before the Prussians in I870 France turned to a republic again with little enthusiasm, little conviction that she had yet found the road to liberty, equality and fraternity - the road seen with such radiant clearness in 1789 and lost so soon.

The political history of modern France is then a melancholy story - a story, on the surface, of failure and disillusionment and little else. And yet it is not without inspiration. For it is the story of a failure far from ignoble, of a people who had seen a glorious vision and were content with no compromise. They accepted this or that temporary solution to their problem - Napoleon, Louis XVIII, Louis Philippe, Napoleon III, this or some other republican form - only because human strength becomes exhausted, because weariness and discouragement made necessary a pause in the climbing, because under stress of effort and bewilderment ideals grow clouded and the crying need is for rest and peace. But that which unsympathetic onlookers called the revolutionary fever, the burning desire for perfection, aroused the French people again and again to new effort. Until of recent years they have come to see that salvation is not through constitutions, and that the road to perfection may be found 
by a way other than the constant destruction and anxious rebuilding of governmental forms.

Now let us approach the matter from another angle. We have been considering the spirit and aims of the Revolution, and have seen the failure of France to carry out the high program of I789. The reaction of I 815 , the upheavals of 1830 and 1848 , the restoration of the Empire in 1852 all seem singularly futile, barren of actual result, no matter how clearly they may illustrate the persistence of the revolutionary spirit. The creation of the Third Republic was not futile, but in some respects it was more discouraging than the failure of 1848 , for it was based on compromise; the republic stood not because it satisfied France but because nothing better seemed to be available.

All this is true, but it is not the whole truth. The Revolution failed to realize its dream, but it did not wholly fail. Indeed the use of the word dream is a little deceptive in that it implies an ideal based on no thought of practical problems and of past experience. As a matter of fact revolution and reconstruction went hand in hand from the beginning, were indeed different aspects of the same thing. And the men of I 789 - idealists though they might be - were by no means blind visionaries.

Revolution, to us, has perhaps too overwhelming an association. We think of it as the casting of old things 
overboard, the turning of a fresh page, the wiping of the slate, the setting forth on an unknown sea, the breaking of a shell which lies thereafter shattered and discarded by the new life that issues forth. All of these metaphors are used so easily that to some extent they control our thinking. But as a matter of fact a political revolution is seldom a complete overthrow and a completely new start. Its analogy in the life of an individual is perhaps what evangelical Christians call "conversion" - a change undeniably of high and farreaching consequence, but a change which leaves intact one's tastes, one's intellectual gifts and equipment, one's temperament, many of one's habits. It gives all of them a new meaning and a new direction, no doubt, but it does not blot them out. Similarly when we approach the France of 1815 or even more the France of 1870 we must not exaggerate the effects of the whirlwind that had swept her political world, the rapid changes that made her seem to her more sluggish or cautious neighbors a very symbol and type of political instability. The truth was that in 1870 as in 1815 the changes wrought were less impressive than the solidity of that which remained standing after the storm.

For the old system was far from completely destroyed in 1789 , and much of the reconstructive work undertaken at each phase of the revolution remained untouched during the political changes that followed. 
So that in considering even the political side of modern France we must not think of an edifice wrecked again and again to be painfully built again after each convulsion - the present one dating from 1870 . The form seen by the world was broken, indeed; but the reality was left largely intact. If we keep our architectural figure of speech we might even think of Directors, Consuls, Emperors, Kings and Presidents as successive decorative appendages, not as integral parts of the structures of which they were the most visible features. Such a conception would not be quite accurate, indeed, but it would be much safer than to fix our attention solely on names, titles and political forms.

Thus it would be true, for instance, to say that in the matter of government the French Revolution did not achieve complete liberty but did achieve centralization, i. e., it perfected the very form that Richelieu and Colbert had tried to attain in the seventeenth century. The ministers of Louis XIII and Louis XIV had done much in this direction; but they had been hampered by privileges and barriers bequeathed from past ages, obstacles too firmly established to be removed. In one night, the night of August 4, 1789, many of these crumbled to dust. The plan of Richelieu was carried out by the Revolution. The practical French instinct for orderly arrangement triumphed while the more difficult ideal of equality remained an unrealized hope. 
And Napoleon completed what the National Assembly began, until the administrative system was created that flourishes to this day - a division of France into departments, each presided over by a prefect appointed by and responsible to the central government. Nearly all the actual administrative system of France is as Napoleon shaped it; he only reduced to order and consistency the work which the revolutionary assemblies had begun; and the revolutionary assemblies themselves followed precedents and used customs and ideas that belonged to the old régime.

The essential point is that neither an individual nor a nation can change habits, equipment, temperament and ways of thinking in the twinkling of an eye. We must think of the Revolution not primarily as a storm that swept everything away but as a change in political and social perspective, a change that had been working beneath the political surface before 1789 and that in and after that year began to effect a re-arrangement of political and social ideas and forms in accordance with an altered conception of political and social aims. The change was in many ways slow, in a few ways very rapid. Some things, -like the abolition of feudal privileges and the introduction of some measure of national participation in government, were done at once. No delay was needed in the removal of the more obvious abuses, the more irritating and oppressive handi- 
caps. But the full working out of the idea of liberty and the devising of institutions that would represent a satisfactory adjustment of liberty and equality to the ideals of France - this was slow, a matter of education and experiment.

For it must be remembered that the Revolution was the work largely of one class, the bourgeois, that only a small minority of the French people had any considerable hand in any of the political changes from 1789 to I870, that most of the agricultural population and many of even the townspeople remained stubbornly conservative throughout, little interested in the question whether an emperor, a king or a president held sway at Paris provided they were left in peace to live their own lives. The awakening of a whole people to a new idea is bound to be slow and subject to lapses. And human nature is too complex for any one formula to cover its needs - even the intoxicating cry of "liber ty, equality and brotherhood."

So that we may view the political changes of the nineteenth century not as failures so much as experiments, and progressive experiments. And we must remember that all the glamor of the word "liberty" did not conceal from Frenchmen the fact that government is a practical affair in which caution is a virtue, machinery necessary, experience not to be despised, and efficiency by no means to be sacrificed. A con- 
stitution might be found unsatisfactory and might be displaced, but a practical and beneficent reform was to be retained, certainly. Failure to discover the ideal form of government might be discouraging, and might have an unfortunate effect on the body politic, but in the meantime every experiment had its value and experience was teaching its lesson. In other words the failure was external and superficial, due mainly to the essential difficulty of the problem, to passionate intensity of partisanship, and to lack of leadership for though the nineteenth century produced many great Frenchmen there was not in the list a single statesman of the first rank. But it was failure that was perfectly consistent with definite and steady progress in the - fundamentals of government - law, order, and equal justice - and with brilliant achievements in every other field of national life.

What France needed above all things at the opening of the twentieth century was courage, self-confidence. realization that the form mattered less than the reality. And the Marne, Verdun, the restoration of AlsaceLorraine have perhaps given her the one thing necessary. We may yet see the long and valiant progress in reconstruction end in triumph, the principles of the Revolution adjusted to the spirit and genius of France. For she has never lost sight of the goal; she has never given up her strong and patient search for the road; 
36 RECONSTRUCTION AND NATIONAL LIFE

she has never relapsed into apathy, however weary and discouraged she might be; and the wiping out of the disaster of 1870 has given her a new and splendid courage. 


\section{III}

\section{The French Revolution and National Life}

WE shall try now to see the working out, the adjustment, the modification, the progressive understanding of the principles of the Revolution not in political changes, not in constitutional experiments, but in things that expressed and affected the French people in their ways of looking at life. They found it difficult to work out a political creed beyond its fundamental propositions of liberty and equality, even more difficult to work out a form that would express even such articles of the creed as they did see and accept. But they could and did set about the task of education, and they could apply their energies to the fields of art, literature and social betterment. In these we may see the national genius seizing on all the fundamental principles of the Revolution - liberty, sincerity, the return to nature - and still remaining essentially French, with the French passion for lucidity, magnificence and idealism. Sometimes these seem to clash, - lucidity with libetty, magnificence with sincerity and simplicity, idealism with naturalism. But the conflict was not irreconcilable, and the study of 
some of its phases may help us to understand $s$ the education of the French people for their new era, the basis of their problem of reconstruction. We shall discuss here only three lines of development - education, because it is fundamental, painting, because it throws light on some of the most interesting sides of the new French spirit, and the entry of the workingmen into politics because it is a peculiarly vital element in present-day France.

I. Thirty years before the Revolution Diderot had mapped out a plan of national education, a scheme of the centralized, clearly apprehended sort dear to the French mind, by which the University at Paris should be the top of a pyramid and a universal system of schools its base. This remained a suggestion until the end of the old régime. But among the projects laid before the representatives of France in the early nineties were several proposals for a national system of education along the lines indicated by Diderot. And while it was easier in those agitated years to pass resolutions than to undertake the immense task of bringing into being a great body of schools demanding skilled teachers, careful supervision, and the consideration of innumerable details of administration and method, yet the new spirit was clearly manifest. Leaders of all parties agreed that a free state must rest on intelligent citizenship, and Danton even advocated 
the taking over of all children from the uneven and often unintelligent control of their parents to be educated by the nation at the nation's expense.

Moreover a change took place in the whole conception of the content and purpose of education. The schools of pre-revolutionary France were classical schools for the training of scholars, professional men and gentlemen. Their curriculum ignored the "practical" studies that might contribute to the life of the ordinary citizen. For ages the religious ideal had dominated the schools of the Christian world, until the Renaissance added to the religious ideal that of literary appreciation and classical scholarship. The scientific renaissance of the seventeenth century had begun an active movement for the introduction of science to the curriculum; but the effect of the scientific impulse had been slight up to I789, and the actual schools of the eighteenth century were schools of polite learning - and polite religion - for the upper classes. With the Revolution came a new ideal and the beginning of a revision in curriculum and method which have persisted and developed to the present day. ${ }^{1}$

1 We use the word "beginning" with the usual reservations. It is the common and not uninstructive experience of the historical student to find that a movement that "began" at some stated time had really been going on for generations or centuries. The point of this word of caution here may be seen by any one who cares to look into the educational ideas of, say, Rabelais and Comenius. 
The ideal was intelligent citizenship, "social efficiency"; the revision of the curriculum was in the direction of subordinating the classics to history, geography, natural science and the modern languages and literature; the change of method was along the line suggested by the Emile and developed by the Swiss teacher Pestalozzi.

The whole educational change was so profound, demanded the study and digestion of so complex a mass of details, that it was bound to be slow. The theorists of the eighteenth century saw the general idea quite clearly, but we can concede the merits of their program without blaming them for failing to realize it. No matter how just a plan or how true a theory there are always innumerable obstacles to a great educational reform in prejudices to be conciliated, traditions to be conquered, machinery to be devised, detailed plans to be worked out. The essential point is that the need for public education was seen and faced, an integral element in the hopes and plans of the new France. It was given a preliminary form by Napoleon's creation of the University of France, a system of national education controlled from top to bottom by the head of the University in Paris; it was limited in scope by the Emperor's desire to check the immense popular forces that had given him his power and might menace it in future, and it suffered from the re- 
action and the exhaustion of France's vitality after I8I5; but it revived with the expulsion of Charles $\mathrm{X}$ and the comparative liberalism of the thirties, and

$\rightarrow$ has moved steadily ahead ever since.

Education in France has lacked the brilliant reformers whose genius gave peculiar interest to the educational movement in Germany. But it has suffered less from the domination of a narrow and stifling if undeniably efficient control, for while the French school - system is absolutely centralized, supervised by the government as completely as in Germany, yet France was never Prussia. Political influence has often worked harm. But on the whole the program of the Revolution has been nobly carried through. In I 789 fifty per cent. of the men in France and seventy-five per cent. of the women could not sign their names. By 1870 the percentage of illiteracy was reduced to twenty-five for men and thirty-seven for women. By 1898 it was cut down to five and seven, respectively. And by the opening of the war illiteracy had almost disappeared. ${ }^{1}$ It is impossible to measure the significance of such a progress. For the future of France it means incomparably more than the achievements of a few brilliant leaders.

1 For reference see Monroe, Text-book in the History of Education (Macmillan), and Farrington, French Secondary Schools (Longmans), and The Public Primary School System of France (Teachers' College, Columbia University, 1906). 
2. The student who wishes to see at a glance the historical and human interest of painting should place side by side any characteristic work of Watteau, Greuze, Millet and - say - Cezanne. Let us eliminate the question of like or dislike and quite ignore the point of view of the "art critic." Let us simply remember that every painter, willingly or unwillingly, consciously or unconsciously, reflects the tastes and interests of the people for whom he paints, the environment which has molded his own attitude to life.

Watteau's picture stands for a single class - the pleasure-loving, irresponsible aristocracy of the old régime. It fits harmoniously into a Luxembourg drawing room of Louis XV. It is dainty, gay, full of the spirit that we associate with the ball room and the banquet hall. Its world is not a fairy world avowedly remote from all that is visible and prosaic but perfectly real to the imagination of every one, king or peasant, who has ever been a normal child; it is not the world of the ordinary man, the world of nature and of daily life; it is not even the world of great deeds, of heroic or inspiring moments, or the world of allegory, or the world of religion, with their wide appeal to dramatic, ethical or spiritual instincts. It is a world beautiful in its own way but essentially artificial and narrow, a hot-house flowering, foredoomed to perish.

In the midst of this society of gaiety and careless- 
ness arose a new fashion in the later days of Louis $\mathrm{XV}$ - the fashion that we associate with the name of Rousseau. The world was soon to know the tremendous potency of the gospel of nature. But while it spread like a flame among the middle and lower classes it was welcomed as a new plaything by the aristocracy. There is a strange pathos in the little hamlet built in the park at Versailles, with cottages like the cottages of the peasants, where Marie Antoinette and her court ladies played at the simple and rural life. It was as unreal as the shepherdesses and swains of painting and poetry. But it had its beauty even if its tragic side was still unsuspected. And it is this cult of simplicity and pseudo-naturalism that one sees in the pictures of Greuze. They are neither real nor unreal. They have the beauty and the truth of the light that heralds a devastating forest fire.

Millet and his contemporaries came after the fire had roared by. They were of a new world, and it was for the new world that they painted, a world that was still struggling to find its way among the relics and débris of the conflagration. Rousseau's message had been purged of much of its fantastic and unreal element and had passed into a world-wide feeling for the eternal wisdom and beauty of nature, a world-wide interest in the "common man" whose life was based on solid things. It is this that is voiced by Millet. The 
delight in nature's reality and peace is just as distinctive of the new era as political and social democracy, and we may find it variously expressed not only in Millet but in Corot, in Troyon, in Diaz and in Theodore Rousseau. All of these are deeply significant, and it is difficult to speak of them with moderation, so truly and nobly do they interpret some of the finest and most fruitful visions and convictions of the new France.

Finally there is Cezanne. $\mathrm{He}$ is, we admit, an extreme case. Moreover, to appreciate his work we should study it in relation to the whole development of modern French art. But this is not a history of French painting, and we wish to glance at a picture of Cezanne's only to see in it an expression of presentday France. We might just as well take a picture by Manet, by Matisse, or by a dozen others. All illustrate at once a passion for truth and insistence on the right of the individual to interpret truth in his own way. Truth and beauty are seen not as abstract and as universal ideas but as individual reactions, each man his own measure of what is true and what is beautiful. There is something defiant and challenging about recent French painting. It has deserted many of the old standards, and in doing so it has deserted, it seems to many of us, some of the things best worth while in art. "You do not like," the artist says to us, "the subject 
I have chosen. Very well - I do. You do not think I have painted things as you see them. No, but I have painted things as I see them, which is all a painter ought to do if he is to be genuine."

It has often been a matter of comment that the political, social and intellectual revolutionary era of the close of the eighteenth century and the beginning of the nineteenth was not accompanied by a revolution in painting. The painters of that time were severely classic, willing to portray subjects of contemporary interest but with no changed conception of their art.

$\sim$ But the revolution has come in our own day, and it is not easy yet to see signs of reconstruction. It is vigorously individual, painstaking, intent on scientific exactness, full of power, recklessly regardless of conven- tion, the expression of men almost furiously alive, with - eyes to the future and backs to the past. To the ordinary onlooker modern French art is a chaos of uninteresting, transient, experimental efforts to portray commonplace things with a minimum of inspiration a chaos shot by gleams of beauty, indeed, but in the main redeemed only by its unmistakable signs of sincerity and of search. Yet it is part of France, wading through swamps and unlovely plains, perhaps, but wading with unconquerable belief that the miry road leads to heights undreamed of by the older painters. It may be so, and we can admire the faith and the en- 
thusiasm even if we cannot ourselves see the Vision.

3. We put aside with regret the contribution of literature, albeit almost yielding to the temptation to discuss the value of, say, Victor Hugo, Flaubert, Guy de Maupassant, Daudet and Romain Rolland as interpreters of French life and thought. But it is necessary to give what space remains to us for the study of France to the workingmen, and to one phase of their activities - the effort to reconstruct society on a sounder economic basis. In other words we have to survey, all too briefly, the growth of French socialism and of its offshoot or heresy, syndicalism.

The industrial revolution was late in reaching France. The factory system did not assume importance until the later years of Louis Philippe, and the first clear sign of the entry of the workingman into French politics was seen in the revolution of 1848 . Socialism existed before that year, indeed, but in a wild, Utopian, idealistic form. Its most noteworthy apostle had been Fourier, and his remedy for social ills was the resolving of the state into small communities of the kind advocated by Robert Owen in England and tried out with little success in two well-known experiments in America - at New Harmony, Indiana and Brook Farm, Massachusetts. But this gave place in the forties to a movement more like the socialism of to-day, and its exponent was Louis Blanc. His scheme, in 
brief, was first - in order of time - the creation of an absolutely democratic state, and then the ending of capitalistic control of industry by the forming of social workshops, wasteful competition and the tyranny of a class being abolished by public ownership. As a protest and as a sign of coming events Louis Blanc's proposal had interest and value, but it was never given a fair trial; the solid opposition of peasants and bourgeois alike - i. e., the vast majority of the nation to any radical change was too much for the comparatively feeble force of socialism; the experiment that Louis Blanc was permitted to make in the spring of I 848 was hampered by impossible conditions; it ended in a furious battle in the streets of Paris, and the nation's fear of radicalism had much to do with the end of the Second Republic in 1852 .

For a time socialism seemed dead, but in the fifties and the sixties it arose again in more menacing form under the leadership of two gifted German Jews, Ferdinand Lassalle and Karl Marx. This new socialism will be discussed in another chapter, but its essence may be stated here in the words of Lassalle. "Division of labor is really common labor, social combination for production. This, the real nature of production, needs only to be explicitly recognized. In the total production therefore, it is merely requisite to abolish individual portions of capital and to conduct 
the labor of society which is already common, with the common capital of society, and to distribute the result of production among all who have contributed to it, in proportion to their performance." ? This is frequently known as collectivism, but as worked out in detail by Karl Marx it is practically what is meant nine times out of ten when the word "socialism" is used to-day. . It spread rapidly from Germany to France as to all the industrial countries of the world, and became a mighty and increasing force from the time of Marx and Lassalle to the present.

The ideal of socialism had at least an appearance of being identical with liberty, equality and fraternity. Moreover any practical working out of the idea implied a highly centralized machinery. Both theory and method would seem to be in a peculiar degree consistent with French traditions, for if liberty and equality were the goals of the Revolution centralization of administration was apparently an essential feature of the traditional French conception of government. And as a matter of fact the socialist party in France when the twentieth century opened numbered more adherents, relatively to other parties, than in any other country in the world except Germany.

But French socialism was never as solid and homogeneous as that of Germany. For it became increas-

1 Kirkup, History of Socialism, p. 105. 
ingly evident as time went on that French radicalism was more deep seated than German, even as it was probably true that French conservatism was more stubborn. And the views of the workingmen of France shaded off from orthodox Marxianism to anarchism in infinite and complex gradations. The ideal of liberty was more powerful than the tradition of centralization, and discipline, organization, solidarity appealed less to the Gaul than to the German. So that the result in recent years has been the recession of social democracy and the rise of militant trade unionism or syndicalism.

Syndicalism is in a sense the offspring of the two great opposites - socialism and anarchism. Socialism would make the word "people" mean the workers private capital being abolished and "parasites" being compelled to work or starve - and would make the State the people organized for government. The State, i. e., the people, i. e., the workers, is to be all-powerful, owning the instruments of production, land and capital, and controlling all production and distribution. The anarchist, on the other hand, would do away with the state entirely, for even the socialist government notwithstanding its plausible theory - would lend itself to manipulation by crafty and unprincipled politicians. The anarchist ideal is untrammeled liberty, and society is to be a matter of free, coöperative as- 
sociation binding on no one. Anarchism was indeed a much more logical deduction from the "liberty, equality and fraternity" slogan than socialism. It was born in the mind of a Frenchman, Proud'hon, and a French rebel against existing conditions was much more apt to take to anarchism than to any theory of an organic and all-powerful state. But anarchism has the disadvantage of being purely negative, lacking any clear and constructive goal, basing its hopes for the future on the seductive but unconvincing doctrine that human nature is essentially good and wise, that evil springs solely from the artificial restraint of government. Anarchism and socialism are agreed, then, in condemning private capitalism, the present social system. But in their program beyond that point they are at opposite poles.

Syndicalism represents their happy reconciliation. Syndicat is simply the French word for Trade Union, and syndicalism as an organized movement appeared first when the Confederation Generale du Travail was organized in 1895 by a group of unions who saw possibilities in the idea of a general strike. In 1902 this was joined by the bourses $d u$ travail, Chambers of Labor, workingmen's societies which had been formed in Paris and other cities for the discussion of labor problems, and which had federated in 1892 . The 
combined organization became a Confederation of industrial unions in which the trade or craft unions had been merged, i. e., the units of the Confederation were not carpenters, masons, locomotive engineers, tailors. and the like but all engaged in the building trades, all in railroading, all in the clothing industry and so on. So that if the carpenters went on strike they would be joined by their fellows of the various craftsmen associated with them in building, and the area of the strike would be widened with an immense increase of force. With the new weapon of the general strike the Confederation adopted the principle of "direct action": i. e., it disdained politics and relied on labor alone. Anything and everything that could weaken and discourage the capitalist - including, for instance, the famous or infamous method of sabotage, deliberate injury to the plant - was considered legitimate. In the "class war" all was fair.

The whole movement was given coherence and a certain doubtful clearness by Georges Sorel, the Karl Marx of Syndicalism. Yet to compare Sorel with the apostle of "scientific" socialism is misleading. $\mathrm{He}$ does not try to enunciate any definite, logical system. He believes rather in the value of the " social myth," the unproved and perhaps unprovable belief that sweeps mankind to the heights by the very vagueness of its 
grandeur. The myth does not need to be true; it may never be translated into fact; it does its work if it inspires enthusiasm and above all if it leads to action. For action, not logic, scientific accuracy, or intelligence is the force that awakens and redeems, and action springs not from reason but from an ideal, a myth, whose exact truth is an insignificant matter. To the ordinary mind this is at first sight discouraging and somewhat bewildering, but it has its point and is not in itself revolutionary. Sorel's real menace lies in his specific gospel. $\mathrm{He}$ believes in the regeneration of society through the regeneration and omnipotence of the working class - the only class - in his view, that is worth considering. And this is to be attained not through politics, not through democracy, and not through state socialism, but through organized labor and direct action. The ownership of capital by all the workers - the socialist state - is a.scientific delusion; it would mean bureaucracy and corruption. Let labor rely on the autonomous development of industrial unions; let the capital required in each industry be owned and controlled by the workers of that industry, those whose interest is directly concerned in that field of production. - These unions - federated by all means but not bound by any hard and fast constitution or body of law - represent all the government that mankind needs. Reform through politics and 
laws is wasted effort; the real issue is the " class war," and the real goal is the liberty and supremacy of the working class. ${ }^{1}$

This is neither anarchism nor socialism. It partakes of both. But it has the constructive ideal lacked by anarchism and the tangible conviction of liberty lacked by socialism. And its interest to us for the purpose of this particular study is not in its validity or its falsity but in the fact that it is a great and growing power in France and in the additional fact that it is a direct challenge to the centralization that is supposed to be peculiarly French. The French state has been undoubtedly dominated by the centralizing idea. But the actual government of France has been slipping away from centralization with every decade of the Third Republic, and syndicalism strikes at its very root. So perhaps France may yet cast aside the method beloved of Colbert, adopted by the National Assembly and the Convention, perfected by Napoleon and retained through the nineteenth century. There has been no visible change in the form of the French constitution since 1870-1875. But every aspect of French life has been instinct with revolt during the last

1 The menace of syndicalism is of course its program of class domination. And the rock on which it will split will be the peasantrv, the element in the country which the radicals so yersistently ignore. Syndicalism is known best in America through the activities of the I. W. W. 
twenty years and the fiery enthusiasm and strength of soul awakened by the war will hardly check the currents of radicalism. Whether the syndicalist disintegration of society will continue and triumph remains to be seen. But it is a force to be reckoned with.

What then is the upshot of even so brief a survey of - the progress of France since the Revolution? Such conclusions as we might reach would be only confirmed and illustrated if we were to add to our view the message of literature and philosophy. ${ }^{1}$ And these, tentatively stated, are fourfold: that the notion of France as decadent and degenerate is and always was superficial and quite false, that the story of her political rev- 2 olutions since I8I 5 is singularly inconsequent, throws little real light on her national development, that her 3 effort to attain a liberty and a social order that would make possible the highest degree of sanity, equality of opportunity and progress has been vigorous and continuous, and finally that this effort is still going on, is 4 still incomplete.

We repeat then that the reconstruction of France must mean to us not simply reconstruction after the tremendous crisis of the war. The invasion of I9I4 was a menace to her whole national life, a threatened

1 It has been well remarked that Sorel's doctrines are closely akin to those of Henri Bergson. See Ramsay Macdonald, Synlicalism, pp. 18-22, and Lewis, Syndicalism and the General Strike, pp. $54-55$. 
interruption to her progress toward the national salvation that she has been working out for five generations. As such it had to be met with her full powers of resistance, for victory was a matter of life or death. But the coming of peace means more than the end of a long and anxious strain. It means the picking up of the threads of national advance with a deeper earnestness and a fuller confidence, the fixing of the eye once more on the Celestial City that was not forgotten during the fight with Apollyon - whose glory and desirableness shone indeed and still shines with greater splendor because of the battle. In fine, the basis of reconstruction is not one of constitutional forms, of political ambitions or of rectified frontiers; it is the living spirit of France, cautious yet iconoclastic, skeptical yet glowing with faith, proud of her great memories yet still striving confidently toward an ideal - the realization of liberty, equality and brotherhood. 


\section{The Basis of Reconstruction in Germany}

AT the present moment Germany is probably the most interesting spot on the globe to the student of society and nationality. Twenty years ago any of us would have said that the German people had found the permanent solution of their national problem in the Empire. Not that the empire was necessarily to remain autocratic and militaristic, for the Social Democracy was recognized as a growing force that would inevitably cause a modification of the constitution and of the general attitude of the Empire both to liberty and to world politics; but no one anticipated any fundamental change. In essentials, we thought, Germany had found herself. Yet we have seen the Empire collapse and the whole form and future of German nationality thrown into solution. Only in Russia, among all the great peoples of the world, is the problem so acute, the issue so uncertain. And nowhere, if we wish to follow intelligently the events of the next few years, is it so necessary to understand the basis of national life on which reconstruction is to stand. 
It has become a commonplace during the war to say that Germany meant really two separate things - the German people and Prussia. Commonplaces are not always true, but in this case the observation was accurate and even fundamental, true as it was that in the war itself the German people and Prussia were one. A single illustration will serve. If any intelligent person had been asked in, let us say, 1850, to name a few representative Germans his list would have included Martin Luther, Goethe, Schiller, Kant, Hegel, Lessing, Beethoven, Niebuhr, and perhaps a dozen others of the same type. Rather less certainly there would be three statesmen, the Great Elector, Frederick the Great and Stein - two of them Hohenzollerns and the third a minister of Prussia; but none of these except Frederick the Great would be as familiar names to the world at large as those of the poets and musicians. If the same question had been asked at any time between 1870 and 19I4 the name of Bismarck would have leaped out automatically, first on the list, overshadowing all the rest. That is to say, the preëminent German achievements before 1850 were in the fields of philosophy, literature, music, philology, history: since 1870 there have been added the construction of a great State and the organization that made possible an immense development of industry and commerce. And the nearness of the recent phase, the strik- 
ing and even spectacular character of German exploits since 1866 , the fascination both of enormous military power and of world-wide economic expansion, have distorted our perspective.

Since August, I914, moreover, the giant has become an ogre, and for years to come it will be difficult to dissociate from the German name a cold-blooded inhumanity, destructiveness, arrogance and treachery that made a race honored and even loved appear to the world as a loathsome plague. Yet the student of society cannot rest content with this. $\mathrm{He}$ cannot allow the events of less than half a century to obliterate the memory of a thousand years. He must keep in mind the old Germany as well as the Germany of Bismarck, the Germany of Wittemberg and Weimar as well as the Germany of Louvain and the Lusitania; he must remember that the Empire lasted less than fifty years; and he must face the fact that a sound reconstruction, the national redemption of the German people, is a matter of enormous consequence to the whole world. We cannot ignore the policy of "blood and iron," the evil deeds of I9I4-I8, but neither can we fix our eyes exclusively on one epoch and one phase of that epoch without being led to false conclusions.

We shall try first to see what is meant by the phrase "the older Germany." Those who view the older Germany as dead will regard its study as more or less 
academic, as part of the history of humanity and therefore having its contribution, but as having no direct bearing on the problem of German reconstruction. - Few students will share such a view. An individual may indeed undergo radical transformation in a brief period. New temptations or crises may develop hitherto dormant and unsuspected weaknesses and the structure of character may collapse as a healthy bodily frame may be disintegrated by a deadly disease; new light and new inspiration may arouse forces of strength and virtue that will bring about regeneration and moral upbuilding. But a whole people is not so easily changed. Nations do indeed pass through crises, undergo new experiences, suffer modifications for good and evil that often suggest a parallel to the conversion, the awakening, the degeneration of an individual. But the national mass is so complex that its changes are bound to be less radical and less rapid than those of a single human being, and the parallel is only suggestive, not conclusive. We shall refuse to admit then that the Germany of the future is any more apt to resemble the Germany of Bismarck than the Germany of Goethe. There has been a change, no doubt, but neither the splendor nor the blunders and crimes of the last phase of German history convince us that continuity was irreparably broken. The old foundations are still there and much of the superstructure may need only repair 
and alteration, even if a new plan be adopted, some of the decoration and walls be torn down, and the architects be dismissed.

Politically, Germany did not exist in the eighteenth century at all. It was brought into being by the hammer strokes of Napoleon. When the States General of France met at Versailles in I789 there were over three hundred independent states in what we now call Germany, and Austria was as much a German state as Bavaria or Saxony. They were held together in theory by the shadow of a great name, the Empire, but the title of Emperor - held usually, since the thirtenth century, by the head of the House of Hapsburg - meant only dignity, a certain splendor hallowed by associations, by memories of Frederick Barbarossa, Otto the Great, Charlemagne and Augustus, but no power. Germany was ruled by its princes - kings, dukes, grand dukes, bishops, knights - each absolute in his own domain, the only exceptions to this miscellany of autocracy being the thirty free cities. There was no room for national feeling or for patriotism. "Of love of country," said Lessing, "I have no conception. To me it seems at best but an heroic weakness which I am right glad to be without."

If any German of that time could have been led to speculate on the question of national unity he might 
have considered three possibilities - voluntary federation, forcible union under the Hapsburgs, forcible union under the Hohenzollerns. The first he would have dismissed at once as inconceivable. The second was conceivable, given a pre-eminent political and military genius, but it would mean another Thirty Years' War and would be regarded as a supreme disaster by every German outside of Austria. The third was even less likely. Prussia, it is true, was not handicapped as was Austria by a great non-German population; apart from her Polish subjects she was a German state; but in the eighteenth century this was a matter of indifference. Austria's. Slavic and Magyar subjects formed just as good tax-payers and soldiers as her Germans; all were alike pawns to be played as Vienna willed; and under normally equal leadership Austria's power was greater than that of Prussia. Still Frederick the Great had shown that genius could wipe out the difference in man-power and wealth, and Prussia was at least a possibility as the mistress of Germany. A bare possibility, however; even Frederick had not attempted an adventure which would have united against him all his neighbors. On the whole, German unity was not even a dream, not even desired, not an element in practical or even Utopian politics.

But on the other hand if since there was no German 
nation ${ }^{1}$ there was no room for national patriotism there was much room for pride of race. The German could look back to at least two eras in which his people had figured in the world with honor and power. One was the age of the Hanseatic League, when German merchants were lords of the Baltic, when they practically controlled the trade of northern Europe and extended their influence far south to the Mediterranean, when the German cities had freed themselves from the rule of the princes and had no equals in power and wealth outside of Italy. And the other was the age of Luther, when the friar of Wittemberg raised his banner of revolt against papal domination. The Hanseatic League had lost its proud greatness by the end of the fifteenth century, and the followers of Luther - had within two generations forgotten his noble faith and thrown away their great opportunity in political and sectarian quarrels. But the race that had produced the merchant princes of Lübeck and the reformers of the sixteenth century could surely not thereafter remain barren. Nor indeed had it remained barren. Mozart and Beethoven were both living in I789, representatives of a movement deep, broad, and full of splendor. We cannot discuss here the contribution of music - the one debt of the world to Germany that is

1 That is, politically; the expression "German nation" was used sometimes in the non-political sense of "German people." 
least disputed. It was another proof of a many-sided and fruitful genius. Yet like the greatness of the Hansa, like the greatness of Luther and his contemporaries, so the greatness of the masters of music had nothing to do with national unity. They were Germans, but in a very true sense they were men without a country.

Of all the social movements in Germany before the nineteenth century the Reformation is, no doubt, the most instructive. As far as German unity was concerned it had held out the greatest promise and had resulted in the most discouraging failure. It had ended in the shattering disaster of the Thirty Years' War. But the calamities of the sixteenth and seventeenth centuries were traceable to a single cause - an utter lack of solidarity on the part of the people of which political disunion was only the most visible sign. The very definiteness of the evil was a warning that might, if the evil were not too deep-seated, lead to a remedy. Moreover this lack of solidarity had, one might think, a certain element of promise in its resentment of external control, its vigorous individualism. And there was added to this individualism a high moral principle to which Luther gave powerful expression and which did not die with him - the principle of service and duty, long held to be peculiarly German. "A Christian man is the freest of all, and subject to none. 
A Christian man is the most dutiful servant of all, and subject to every one." These are the two propositions with which Luther began his essay On the Liberty of a Christian Man. This emphasis of individualism and of the moral law may seem curious to those who think only of the Germany of recent years, but it will seem less so after a little reflection, and in any case we are dealing at present with the older Germany. The "ancient German freedom" and "German honesty and kindliness" were commonplace phrases not so long ago, and few observers doubted their essential truth.

Moreover, Luther expressed in the most fundamental article of his religious revolt, another element which was characteristically German and was deeply significant for both good and ill. Wo $+\cdots$ to his revival and emphasis of the doctrine of justification by faith. We must not examine this too closely, nor must we insist too absolutely on consistency in application. But the essential principle involved in justification by faith is unmistakable. It meant protest against the doctrine of salvation through externals - indulgences, penance, priestly absolution, dispensations or anything of the sort - and the emphasis of direct communion with God. Carried to its logical conclusion this would naturally lead to the dissolution of any kind of imposed creeds or rules of conduct, and just as naturally the 
doctrine was not usually pushed so far. But the implication was there, nevertheless, and the tendency. It is related on the one hand to the German mysticism of the Middle Ages and on the other to the idealism of Kant and his successors. And the mental attitude involved was what was meant when the Germans were described as the most religious of all the peoples of Europe. Hegel summed it up exactly when he referred to the "ancient and constantly preserved inwardness of the German people."

So that a German of the end of the eighteenth century could find not only pride in the memory of the Hanseatic merchants and of Luther, in the glory of Bach and Handel, but a real standard for estimating the capacities and character of his people. Music was in a class of its own, difficult to analyze in its relation to the actual world but of unquestioned power and value. The Hansa and Luther in different ways exemplified the essential quality of practical initiative - the merchants in asserting and winning independence and in making for themselves a great place in the commercial world, the reformer in throwing off the control of an ecclesiastical bondage of immense power. , And Luther furthermore expressed three things that were held for ages to be fundamental elements - of the German character - spiritual freedom, the sense of duty, and " inwardness," the feeling that the kingdom 
of God, i. e., all wisdom and truth, is within you. So much for the things in which our imaginary German of 1789 might reasonably take some pride and comfort. But he might or might not have seen a certain terrible and permanent significance in the age that followed the Diet of Worms. Luther had freed Germany from an external religious authority. $\mathrm{He}$ had substituted the authority of God alone, revealed by faith with the aid of God's word, the Bible. And then was seen a curious thing. The Germans, following their inner light, became split into sects, more intolerant as Protestants than they had ever been as Catholics, intent on minute points of doctrine and discipline, divided and dogmatic, superstitious and cruel. Their "inwardness" had betrayed them. Each one his own prophet, they displayed a fanaticism for the subjective religion framed in their own inner consciousness that they had never shown for the more external religion that they had learned from Rome. Justification by faith implied liberty and service, Luther had said. The Germans made it imply intolerance and formalism. This "religio-ethical disease," as Professor Pfleiderer calls it, was simply the outgrowth of a tendency to intense introspection that is faith caricatured and become pathological, an arrogant confidence in one's own broodings, a faith that despises experience and regards the wisdom of others as Satanic 
if it denies the glory of the idea evolved from the individual soul. And it is well to keep this in mind when we try to understand the modern German - the subjective idealism, the easy mastery by an idea, of one who will fight and die in indignant protest against an external anthority.

From the Reformation to the middle of the eighteenth century, individualism held sway in German thought. We do not speak of German politics because the government of the German states was everywhere autocratic and because political life did not exist as a national function: As always under an autocratic régime there were good rulers and bad, but in either case government was wholly the affair of the prince. The Germany of our time, the German nation, was still an unfused mass, and the German character was to be seen only in fields other than politics. But so far as it could be estimated one could only say that the political divisions faithfully reflected the state of the German mind - the individualism that had expressed itself in the Lutheran revolt reinforced by the spiritual arrogance, sectarianism and formalism that characterized Protestantism after Luther. Not that this unhappy aftermath of the Reformation was universal; there were some - the Moravians, for example - who stood faithfully for a living and spiritual religious life; but these were the minority. Un- 
til at last the German mind began to grow restive again, to give signs that it was about to break its selfimposed yoke of narrow externalism and fruitless pride in petty things. The beginning of the change was seen in Wieland and Lessing. And then the outburst came in dazzling glory with the age of Herder, Kant and Goethe.

With the last quarter of the eighteenth century Germany entered on a new era. It would be untrue to say that either individualism or subjectiveness disappeared; indeed both became stronger than ever; but from whatever source there entered into German thought a new and immense vitality. It sought at first no expression in national unity, nor did it greatly concern itself with politics, though time and again there were signs that poets and thinkers were eyeing resentfully, with only half-restrained bitterness, the corruption of courts and the irresponsibility of the princes. But while there was in Germany none of the revolutionary spirit voiced in France by Voltaire and Rousseau, there was a vigor, a penetrating vision of reality, a breadth of interest in all aspects of life that was bound to act as a spiritual stimulus and tonic to the German people. The pettiness, the morbid introspection and the formalism of the seventeenth and early eighteenth centuries gave place to a wide enthusiasm for all things human. And forms, whether of reli- 
gion, poetry or politics were viewed as living embodiments of the organic forces that had created them. New life always brings the possibility of revolution if the enclosing forms endeavor to restrain and smother it. But in this case if the possibility existed it did not show itself, or at any rate it developed slowly; for the leaders of the revival were not particularly interested in politics, and their work in literature and philosophy was allowed to go on without interference; indeed it was encouraged by the princes, since it did not menace their privileges and did add to their glory.

It would be an impertinence to attempt in the space at our disposal to discuss one of the golden ages of the world's literature and reflection. No one word or phrase will describe even the general tendencies that were represented by Kant, Fichte, Goethe, Schiller and their contemporaries. But if we might select one element in it all that was most permanent, most profoundly German, and most powerful in its effect on German thought, we should certainly name idealism. Akin, no doubt, to the same subjectivism, the same "inwardness" that had clouded the German mind in the sixteenth century it came this time not as an obscuring or disintegrating force but as a prophetic interpretation of life that affected the thought of the whole world. Later on indeed, as we shall see, it involved a lapse into idea-worship that might induce mis- 
givings, but not at once. For the moment at least it was part of a magnificent effort to survey the whole world, to break all spiritual bonds, to clear away all obstacles of myth, prejudice and blindness that might conceal the truth, and to find the keys alike to the human heart and to the ultimate secrets of life.

Before we go farther we must clear up one possible source of confusion. We have already used the word "idealism" in relation to France; we shall use it again in relation to England; and here we are using it in relation to Germany. And not only is it used in three different senses in the three connections, but none of them quite correspond to its use in all languages to describe the famous doctrine of Plato.

Idealism is a Greek word and Plato's philosophy gives us the one root from which the different meanings of the word have sprung. To state it briefly Plato's idealism represented belief in absolute reality, absolute truth, as against the apparent reality perceived by our senses. The world of appearances, the world we see and touch, is only a semblance; it appears and disappears, it is solid or a mirage, it may be as vivid in the phantasms of a dream or of delirium as in the apparent certainty of our ordinary sensation, it changes its aspects, crumbles to dust, dissolves into impalpable gases, appears miraculously from seed or with a change of temperature, disappears just as miracu- 
lously at the touch of seen or unseen forces of disintegration; it is, in short, a world of phenomena, of appearances, not of reality. Yet at the same time it is a kind of parable, an allegory, concealing and showing forth the truth as the body of man conceals and reveals his spirit. The great ruler of this visible world, the center and indispensable element in it, is the Sun, without which life would cease. Similarly in the real though invisible world of ideas there is a Sun, the center and source of all that is good, all truth and all life. The eternal search of the man seeking for wisdom is the search for more knowledge of this real world, and the ultimate wisdom is knowledge of what Plato calls the Form of Good, the ideal Sun, so to speak, which - if we like - we may translate God. ${ }^{1}$

Now all idealism is based on this conviction that the world of phenomena, the world of which our physical

1 "The essential Form of the Good is the highest object of knowledge, and this essence, by permeating all created objects, gives them their value. And if we know everything else perfectly without knowing this essence it will profit us nothing." Plato, Republic, 505. "In the world of knowledge the essential Form of Good is the limit of our inquiries and can barely be perceived; but, when perceived, we cannot help concluding that it is in every case the source of all that is bright and beautiful,in the visible world giving birth to light and its master, and in the intellectual world dispensing, immediately and with full authority, truth and reason." Republic, 517. Cf. "Seek ye first the kingdom of God and His righteousness, and all these other things shall be added unto you." 
senses tell us, is not everything, but that there is a much more real and important world that we can neither see nor touch, that we can apprehend only with our mind, with our spiritual sense. ${ }^{1}$ But this faith has taken various forms. The German tends to seek God and truth in his own soul, made in God's image and holding all truth in itself even more truly than the tree is contained in the seed. The French tendency is more objective, to see in a creed, an institution or a gospel the visible formulation of an eternal truth and to follow it with passionate loyalty. The English tendency is also objective, but his idealism is based on experience and he follows it cautiously, only believing it as he sees it embodied in fruitful form. Such a distinction is indeed approximate rather than absolute, but it is in the main a true one.

It may be prejudice that leads us to consider the English idealism the least dangerous of these, the least open to fanaticism. But we may balance such a statement by admitting that the German and the French will take mankind to higher levels, untrammeled as they are by the English insistence on solid standing ground. At all events it seems that the world needs all three, and the practical English speaking world has

1 For example, we cannot see or touch a scientific law. We may see the results of the law of gravitation and the laws of motion, but we cannot see the laws themselves. 
willingly acknowledged its debt to the more daring flights of the French and German mind. But French idealism is easier for the average Englishman or American to understand than German. And when we do adopt German idealism in our thinking it is strongly modified by our conscious or unconscious pragmatism - our wish to see in an idea and a faith some definite bearing on actual life, some solid foundation in experience.

Yet we must at least try to understand the working of the subjective idealism that is so potent in the Teutonic mind. We shall not venture on a discussion of the philosophy of Kant or the development of what is known as transcendental idealism, but we may see how it acts in certain concrete instances. So it will be our task in the following chapter to study the German theory of the State and the modern social and economic Protestantism that has expressed itself in Marxian Socalism and the Social Democracy. In these we may see the principles that we have been discussing - individualism, the sense of duty, idealism - taking form in movements that have become potent factors in the modern world. 


\section{V}

\section{Idealism in German Polittcs}

WE have found that two historical facts could be asserted regarding the Germans of the eighteenth century and the early nineteenth: in the first place they had been for centuries politically divided and ruled by despots ranging in power from the king of Prussia to petty knights whose domain was limited to a castle or a village - a long and severe training in submissiveness; in the second place they had at one time or another proved their capacity for trade and collective action, for spiritual initiative, and for achievements of the first rank in literature, philosophy, and certain fields of art. We have found also that at least three German characteristics could be noted as apparently deep-seated - spiritual individualism, the sense of duty, and sub-i jectiveness. The first and third of these characteristics might seem at times to be identical, but they were not necessarily so, and the acceptance of a subjective ideal might even lead to the temporary submergence of their individualism, might secure the full alliance of the 
sense of duty, and result in an overwhelming religious or political fanaticism. The result of German history and the working of the German mind had been disunion, the alternation of mighty assertiveness and lamentable collapse, and yet the assurance of great natural capacity.

We have now to see whether these characteristics persisted during the period from the Napoleonic era to the present, and if so how they reacted to the modern world and its problems. And we shall try to answer these questions by studying the modern theory of the state and by noting the character of the revolutionary movement known as socialism. Both of these are essentially idealistic. Yet both illustrate the German paradox of intense concentration on the practical combined with equally intense worship of an idea. They are no more characteristic and no more instructive than the history of German education or of German industry. But they have a very direct significance for our purpose. In our study of nineteenth century France we selected for discussion certain nonpolitical aspects of the national life because these seemed more distinctive, more characteristic and more fruitful than any movement in French politics. But even the sides of modern German life that are not directly political have been so largely dominated by intense nationalism that political thought and political 
leaders have had a power and influence unprecedented in Germany itself and quite without any parallel in the modern world. Yet there has been no real break. Modern Germany is the older Germany in a new aspect.

To the average Englishman or American a theory of the State is something academic, having little or no relation to practical politics. If forced to do so an Englishman could doubtless formulate a theory, and if he did it would be based on specific facts of experience, Magna Carta, the Petition of Right, the seventeenth century revolution. He might tell us, perhaps, that the State was the people organized for collective action, for government and defense, for the maintenace of law and order, for protection against menace from without and disruption from within, its prime requisites being strength on the one hand and freedom on the other. Its purpose and basis is individualistic, no matter how strong the national consciousness, how deep the unanalyzed love for England as England. Similarly the American might base his theory of the State on the Declaration of Indeperidence and the Constitution. But except for argumentative and rhetorical purposes the Englishman and the American alike would formulate his theory reluctantly and with difficulty. His devotion to England or the United. States does not depend on a philosophy or on a formal 
definition, and the warmth of his patriotism neither cools nor deepens with the framing of a political creed or the working out of a political philosophy.

With the German it is otherwise. In the old days of division and despotism no theory of the state mattered, for the state was its prince, and according to the old maxim what pleased the prince had the force of law. But even then a thinker or a dreamer might try to ask himself questions about the real basis and reason of social life. The social contract idea had been familiar in European thought for generations before it was made famous and dynamic by Rousseau, but it remained academic in Germany as in England. The formula of "liberty, equality and fraternity" that was so full of inspiring grandeur to the Frenchman awakened but a cold response east of the Rhine. Abstract liberty meant little to the German, and equality even less. What he sought was some explanation for the state that could satisfy his reason more adequately, that would be at the same time more philosophical and more practical. And this he found in the organic theory of the state.

Gradually developed in the later years of the eighteenth century the theory of the state as an organism was fully stated by Hegel in his Philosophy of Right (I82I) and it has had a power in Germany ever since that other peoples find it difficult to comprehend. It 
was not original with Hegel or with any other German thinker; it was based on Plato and Aristotle; but the Greek theory was like a seed planted in fertile soil, and it grew there until it became all-controlling. It was an idea that could be worked out in a philosopher's study by reflection, a half-truth that to other peoples was an interesting and fruitful suggestion but an abstraction, not to be taken as a complete statement of the truth. But the Germans with their love for an idea evolved from thought and with their ancient inability to see life as a whole, adopted the organic theory, applied it to their own political life, and saw nothing else.

Its basis is the proposition that man is essentially a social being, that man as an individual, i. e., man apart from society, does not and cannot exist. Individual liberty is a myth; there is no such thing; liberty can only be social, and the man who tries to realize liberty apart from society will find himself degenerating to the level of the lower animals. As a rational being he is a member of a society, and the State is the form, the body, the actual realization of this rational, social freedom. The State is then an organism just as truly as a tree or a man is an organism, only it is a higher form. The man is a more perfect organism than the horse or the lion; but the State is a more perfect organism still. And as the leaves and branches of a tree 
have no meaning apart from the tree, as the fingers and bones of a man have no meaning apart from the man, so the merchants, the farmers, all men whatsoever have no meaning apart from the body politic the supreme organism of the State. This was laid down in Aristotle, it was illustrated by Rousseau and Herder, it was accepted as part of his whole system of idealistic philosophy by Hegel. And it was adopted by the Germans just at the time when the pressure of painful facts predisposed them to some theory that would crystallize and rationalize their newly awakened dreams of unity.

For the Napoleonic wars had shattered the political system of Germany. Napoleon had crushed Austria and Prussia, had swept scores of petty princes from their thrones, had formed new combinations, had annexed some of the old principalities to France, given others to princes who were disposed to be friendly to the invader, had ended the shadowy Empire with its traditions of Charlemagne and Frederick Barbarossa, and had imposed his will on Berlin and Vienna, carving and recarving, exacting tribute and distributing favors or punishment as his sovereign will dictated. Thoughtful Germans watched with grief the humiliation of the German name - a name so highly honored in philosophy, literature and art, now so shamed in the field of politics. A new sense of patriotism was 
awakened by the sword of a foreign conqueror, and the War of Liberation that finally drove the French armies across the Rhine was the first sign of the possibility of a united Germany. But if Napoleon's fall and the Congress of Vienna brought no attempt to revive the myriad principalities of the past it brought no real union. The dawn and triumph of German patriotism had left the German people with a sense of unfulfillment. And the idea of the State as an organism came as a gleam of light.

Moreover it was applied definitely to Prússia as a state that was already well on the way to maturity, the object lesson that showed their manifest destiny to the German people. Indeed all of the German states were to Hegel farther on the road to spiritual freedom than, for instance, France. For France was led astray by her false notion of equality, a notion utterly irreconcilable with the conception of the State as organic. The equality of fingers and eyes with heart and brain is an absurdity. The equality of men is just as absurd. Not only is it impossible to reconcile with facts but it involves the striving toward a wrong goal. Each man is most free when he is best fulfilling his function as a member of the State. If God has made him a mechanic he should no more seek to be a statesman or a bank-president than the foot should seek to be an eye. And the same line of thought threw new light on the 
conception of duty. The firmly entrenched principle of a moral law was given a new and rational sanction. That was right which was in harmony with the whole organism, and the way was paved for the belief that what the State orders is beyond argument, a " categorical imperative." For the State is the embodiment of the social conscience as well as of the social reason and social liberty. Not that the moral, rational and free individual does not still exist; but individualism itself has meaning and value only in relation to the superorganism of which the individual is a functioning part. The individual and society are terms unintelligible except in relation to one another. ${ }^{1}$

As the nineteenth century went on it brought a steady rise in the influence and power of Prussia, and a steady trend toward an emphasis of the practical that was a new thing in German life. Voltaire's remark that France aimed at the sovereignty of the land, England of the sea, Germany of the clouds, lost its point. German perspective gradually altered, and of the new tendency in the direction of practical efficiency Prussia was the embodiment. Even before Bismarck, von Roon and von Moltke had completed the incomparable political and military machine which struck down Austria in 1866 and France in .1870-I, and be-

1 See the clear and specific statement of this in Bluntschli, Theory of the State, bk. I, ch. I (Oxford, Clarendon Press, 1895). 
fore the rising spirit of nationality had found its form in the German Empire, the organic theory of the State had begun to fade and a new one to appear. The idea of the State as an organism had indeed sunk so deeply. into the German mind that its essential elements survived and were carried on into the new theory. But to the vigorous and impatient minds of Bismarck and his supporters the organic idea had in it too much fatalism, tended too much to make men let events take their course. ${ }^{1}$ An organism grows by inner life, not by coercion and conscious construction. And the Prussians were eager to give German nationality immediate realization in a form that would bring glory, power, and leadership not in the clouds but in the actual world. To the German thinkers of the sixties, the seventies and increasingly during the decades preceding the war the State was not an organism but a structure; or rather it was both, and its supreme quality was Power. Der Staat ist Macht.

The difference is the difference between the words organism and organization. And the change was not simply the thinking out of a new philosophy but the reflection of Germany's new and intense national spirit. The people so long divided longed for unity; they looked resentfully on a past of impotence and longed for a chance to emulate France and England in

1 Treitschke, Politics, vol. I, c. I. 
the fascinating arena of world politics. National patriotism meant national ambition, and Prussia with her "discovery of organization" was the obvious leader in the new quest. Individually powerless, powerless also in their separate states, the Germans threw their immense capacity for concentration into the realization of a state that should be the whole German people organized in a political, economic and cultural unit. All that we have said regarding liberty and equality in a state conceived as an organism would apply still. The individual liberty and equality of the piston and the fly-wheel, of the leaf and the bark, of the foot and the hand are no more absurd than the liberty and equality of men as the French or the Americans conceive them in a perfectly organized state.

And most Germans accepted this with willing enthusiasm. Their old individualism was merged in the new nationalism, their old sense of duty was satisfied by the conviction that the voice of the State was the voice of God, and their old idealism found a new object of worship in the Fatherland and in the religion of Germanism. The new doctrine of the State as a living machine, an organism and yet not so much an organism as the embodiment of German national strength, of the State as Power, was expressed most vividly and clearly by Treitschke. But impatient as is Treitschke with the purely organic theory of the State he is the 
legitimate successor of Hegel nevertheless. Organism had brought forth super-organism, the organic state had led to the super-state, the actualization of the power to strike, to expand, to hold together and to defend whose lack is the one unpardonable sin and whose exercise and triumph is the one supreme political virtue.

From the point of view of reconstruction then we see the Germans venturing during the last century to apply their idealism to politics, bringing to bear on their new religion of the State an immense national enthusiasm and a hitherto unsuspected capacity both for collective action and for practical efficiency. They found thinkers who formulated their creed for them and leaders who translated it into dazzling achievements. The Power which was the State turned on Germans a helpful and kindly countenance, guiding each individual in the way he should go, giving a happy and obedient people a government by experts that was the wonder of the world; while to threats or restraint from without the same godlike State turned an eye of doom, prepared to annihilate all who should keep the German nation from its place in the sun. And such was the aspect of things in I9I4.

But in November, 1918, the structure reared by Bismarck collapsed. The all-essential Power had proved inadequate. And what remains to be seen is whether the capacity for organization discovered during the 
last century will find itself able to effect a new adjustment, to express itself in some more permanent form than the Prussian autocracy and bureaucracy had supplied.

The growth of the German social democracy has thus a double significance. It is the resurgence of the old Protestant individualism, and it represents a theory of organization radically differing from that of Prussia. Whether it will result in dissensions and futilities or in a successful socialist state remains to be seen. Momentary discord is inevitable, just as momentary national humiliation is inevitable. The German people must pay the price of a difficult experiment just as they must pay the price of crimes to which - no matter who was immediately responsible - they gave their consent and coöperation. The real test will come not next month or next year but during the next generation and perhaps the next century.

What then is the goal and the vital force of German socialism? Strangely enough it too sprang from Hegel. It too is an attempt to realize the organic state, and its fundamental protest against the Empire as against all modern states lies in the contention that they are not organic and cannot be, that they are mechanical and rest on a false principle. The normal existing state rests on a contradiction - the separation by law and custom of the workers from the instruments of 
their work, land and capital. Ultimately all society rests on human labor. But labor is helpless without land and capital. And the system that keeps separate elements of production that are by nature and necessity bound together brings about class domination, the existence and even often the despotic rule of idlers and parasites, the entire distortion of the body politic. The capitalist is able to exploit the laborer; the land-owner is able to monopolize or use to selfish advantage fertile fields, indispensable highways, mines, strategic industrial sites; and these two working together create a condition worse than feudalism. There is only one remedy: the reorganization of the State, now diseased and deformed, so that labor will be unhampered and production be liberated from its present handicaps. When this is done the State will indeed be a true organism, healthy and able to progress toward the full realization of human possibilities.

German socialism found its great prophet in Karl Marx, its first apostle and leader in Ferdinand Lassalle. We need not here distinguish between these as founders of modern socialism. Arriving independently at similar conclusions they differed in method, and for a time their followers failed to see their common ground. Marx used as his medium first the Communist League of the forties, then later on the International Workingmen's Association founded 
in 1864; Lassalle worked through his Universal German Workingmen's Association founded in 1863. But the aims of all these were essentially the same. In the words of Marx their purpose was that "of promoting among the working-classes and other classes a self-conscious participation in the process of historical transformation of society that was taking place under their eyes." Their challenge to the world was uttered in the Communist Manifesto of 1848 , uttered in words that are as living to-day as when they were written: "The Communists ${ }^{1}$ do not seek to conceal their views and aims. They declare openly that their purpose can only be obtained by a violent overthrow of all existing arrangements of society. Let the ruling classes tremble at a communistic revolution. The proletariat have nothing to lose in it but their chains; they have a world to win. Proletarians of the world, unite!" And the statutes of the International adopted at Geneva in 1866 declared that "the economic subjection of the laborer to the possessor of the means of labor, i. e., of the sources of life, is the first cause of his political, moral and material servitude, and that the economic emancipation of labor is consequently the great aim to which every political movement ought to be subordinated."

1 Communism in 1848 meant what Socialism means to-day. Both words have changed their significance in the last fift: years, but the confusion is only verbal. 
In 1875 the followers of Lassalle and of Marx, recognizing that their aims and principles were identical, joined forces at Gotha in what was thereafter the German Social Democracy. The International flickered out and died. The Social Democratic Party waxed in strength and solidarity until it became the standard of orthodox socialism, its platform based on the great work of Marx, Capital, the Bible of the movement. To the socialist, Marx in this book destroyed the entire theoretical basis of capitalism, but it was far more than a monument of destructive criticism. It pointed the way to the socialist state as not only the only remedy but the inevitable goal toward which the world was moving.

But the actual form to be assumed by the socialist state remained problematic. Marx himself and many of his followers have been content to point out the inherent defects of the existing system, the rational basis of the socialist remedy, and the certainty of socialism's ultimate triumph. But the explicit practical program of government was to be determined by circumstances and by the march of facts. "Who could say," said Wilhelm Liebknecht thirty years ago, "Who could say what the socialist state of the future is to be? Who could foresee so much as the development of the existing German state for a single year?" Like every 
other living thing the socialist state would grow and change as altered conditions brought the need for new adjustments.

For the triumph of socialism was not regarded only as the triumph of right over wrong. It was the inevitable result of social evolution. As absolutism had been replaced by feudalism, as feudalism had been replaced by the rule of the bourgeois - each change a beneficent one and even the power of capitalișm being regarded as a legitimate and necessary phase of social development - so the bourgeois state is to be replaced by the proletarian. With the victory of the workers the class war of the ages will end. As each class has won power it has exploited those beneath it. But there is no class to be exploited by the workers. Their supremacy will represent the final victory of democracy.

Here, then, is where the readers of the newspapers may take up the story. For socialism, after years of conflict with Prussianism, after a steady advance in numbers and power for sixty years, is confronted with the practical problem of government. No critic of the Social Democracy need feel undue satisfaction in the conflicts between Liebknecht and Ebert, between "Reds" and moderates. Socialism is not proved wrong or unpractical because socialists have different views as to details of procedure. The real test will come when the preliminary disputes are over and when 
a definite effort is made under fairly normal conditions to create a socialist state in Germany. And we can at least make this comment: that the intense devotion of the Germans to an idea added to the German capacity for discipline and organization may lead us to expect that if socialism can succeed anywhere it can succeed in Germany.

To prophesy in these days of rapid change is futile. The Germans had proved their genius in many fields long before I87r. Of their ability to form a political union that would be an adequate expression of their national life the German Empire of I87I-I9I8 was the first test. It has proved a failure; but the marvelous achievements of the last fifty years indicate that while there was a fatal flaw in the machinery yet there was so much success that another experiment may well be tried without discouragement. And this time the German love for a doctrine evolved by thought is better satisfied than under the Empire. The German is terribly Utopian, and he is at the same time terribly practical. From his inability to see life as a whole, from his way of seeing only a part but seeing that part with an intense clearness and conviction have come his successes and his failures. It is now his task to take another dream, another idea, and to reconstruct by its light his shaken and disillusioned country. But if the reconstruction will follow a new plan its basis in the 
German character and in German history is very much what it was in I87I. And if we do not dare to predict the outcome it is because our faith in the solidity and virtue of that foundation has been so sorely shaken. 


\section{VI}

\section{The Russians and the Dawn of Russian}

FREEDOM

When an American, a Frenchman or an Englishman turns to the study of Russia he does well to recognize at the outset that he is entering an alien world. The peoples of western Europe, with all their differences in language, customs, and attitude to life, are yet members of a common family; their lines of political and spiritual development have been intertwined for fifteen centuries; to tell the story of any one of them without mentioning the others would be an absurdity that no one has ever ventured. For all western peoples look back to Rome. All were for ages common children of the Catholic Church. All passed through the age of feudalism. All felt the impact of Mohammedanism and flamed with ardor in the Crusades. All awoke to new intellectual life with the Renaissance, and all were stirred by the religious revolution of the sixteenth century.

But in all of these things Russia had no part. She 
never formed part of the Roman Empire. The jurisdiction of the Pope never touched Kiev or Moscow The spiritual currents and storms of western Europe beat in vain against the invisible wall that stretched from the Baltic to the Bosphorus. And until two hundred years ago Russia was almost as completely out of touch with Europe as the planet Mars. The two worlds did indeed touch for a time at one point. In the tenth century of our era the Russians learned their first lessons in Christianity and civilization under the teachings of Greek missionaries from Constantinople. But before their education was well begun it was interrupted. At the time when representatives of the English towns were meeting in the first House of Commons Russia was falling before the all-conquering Tartars. While the western peoples were slowly escaping from feudalism and feeling the first mighty thrills of the Renaissance, while Dante was writing the Divine Comedy, while Giotto was reviving the art of painting, while Petrarch and Fra Angelico, Boccaccio and Chaucer were each in his own way leading men to new visions of joy and truth, Russia was still prostrate beneath the rule of Asiatic barbarians. And even when a Grand Prince of Moscow led the way in shaking off the Tartar yoke ( 1480 ) it was only to consolidate Russia into an autocracy of the Asiatic type. Under the Czars as under the Khans the people bent submissively 
under the rod, obedient and inert. So that in the seventeenth century, when the men of the west were faring forth on adventures overseas, laying the basis of modern physics and astronomy, and facing the problems of civil and religious liberty, the Russian people had yet to learn their first lessons in civilization as we of the west understand it. Under Grand Princes, Tartar Khans or Czars, they lived in semi-civilized isolation, content to toil or fight at the bidding of their masters, knowing nothing of the vigorous life of the outer world.

The beginning of a new era came with Peter the Great (I689-1725). He found a people essentially Asiatic, their faces turned eastward. He undertook to reverse the current of five centuries, to make Russia European : and to ensure that his work should not perish with him he "broke a window" through the wall that separated his country from the peoples of the west. By the founding of St. Petersburg (Petrograd) he gave Russia her first port on a western sea. Thereafter ships, travelers and merchants came to the Neva and the ideas of the west filtered slowly in - slowly, for the window was a small one, and the people who had so long sat in darkness gave the incoming light no cordial welcome. But if the Russians found it hard to awaken from their Slavic inertia their princes saw vistas open for them in the west far more splendid than 
a barren dominion over the steppes could offer, and bit by bit ambitious Czars made Russia a European power. Gradually and inevitably the Russians learned new and intoxicating lessons from western books. French, English and German literature and thought came to disturb age-hardened conservatism, to awaken new and startling ideas, to stimulate a desire for political, social and intellectual liberty. The new light came only to the few indeed: the millions who cultivated and traded over the vast plains between the White Sea and the Caspian, between the Gulf of Finland and the Ural Hills or in far Siberia, cared little for changes that touched only the leisure classes of Petersburg or Moscow. But by the opening of the nineteenth century the great current of Russian life was slowly shifting westward, and the work of Peter was bearing fruit.

The nineteenth century went on. The French Revolution had brought its shattering and vitalizing message, and Russia had come within the storm-area of the Napoleonic wars. Western Europe was full of dreams of a new social order. Thrones were trembling and the nations were feeling their way toward free and conscious life. Even autocratic princes bowed to the genius of the new era, trying half blindly, sometimes willingly, and sometimes unwillingly, to avert disaster by conciliation and adjustment. Hesi- 
tatingly following the lead of the western rulers the Czar Alexander II liberated the serfs of Russia by a decree of 1861. Forty millions of peasants were freed from bondage to the land, cast adrift on the uncharted sea of personal liberty.

Then came to Russia the Industrial Revolution, with its machinery, its railroads, its factories and its rapid growth of great towns. Peasants by tens of thousands passed from the quiet, unchanging life of the villages to the swirl and stimulus of the cities. The workers learned to talk and read; their minds were gradually stirred to interest in liberty; and they heard with eager curiosity tales of their brethren in other lands. The mental and social awakening that had been hitherto confined to nobles and students spread to the artisans. Army officers, landholders, and wage-earners found themselves comrades in a common cause, sharers in a common aspiration. And the new life in conflict with the machinery of autocratic government brought to birth the strange and mighty force of nihilism.

If we were to seek the spirit of Russia, the dreams, the hopes, the motive forces of the people during the latter half of the nineteenth century, where should we look? The histories speak of " Russia " fighting England and France during the Crimean War, fighting the Turks in 1877-8, being humiliated at the Congress 
of Berlin, entering into alliance with France. But was this really Russia, or was it a small group of offcials acting in the name of the Czar? Or were the Revolutionists the real Russia? Or are we to find the soul of Russia in the vast mass of the Russian people in town and country? Perhaps in all three. For it has happened that even a monarch or an aristocracy clothed with absolute power may in a measure express the inarticulate soul of a people. It is surely not inaccurate to say that in a very true sense "Russia" strove against Swedes and Turks to reach the sea highways and looked wistfully toward Constantinople both as a southern gateway and as a holy city to be redeemed from the infidels.

But it is nevertheless true that we should be far from an understanding of the real Russia if we judged her only by the doings of autocrats, diplomats and generals. At all events we shall leave the Czars to the political historians, or regard them only as their government reacted on Russia herself. With conquests and diplomacy we have here no concern. We shall remember the Emperor and his vast governing machinery only as an overwhelming repressive force, allied with the Church in a never-ceasing effort to keep things as they were, to keep the people devout and obedient, to discourage the dangerous habit of question and criticism. Our effort will be to pierce this rigid shell that 
sought to keep the Russian soul from a too restless wakefulness and to study that soul itself. For in the last twenty years the awakening has come; the shell has been broken; and we need now to understand not the policy of Czars but the aspirations and character of the people.

There is one essential contrast between the spirit of Russia and that of the west which tends to make Russia peculiarly difficult for an American to understand; and yet once the contrast is realized it helps much to throw light on the situation. Take, for instance, the Russian novelists - for a people's stories illuminate their character as does no other single form of expression - and compare them with ours. The tales of America and England are pre-eminently tales of action. Their heroes are men who do things, and even their tragedies are tragedies of struggle, of unrealized ambition, of conflicts of will, of human enterprise thwarted by destiny. Now the Russian novelists do not - with one exception to be noted later dwell on action based on individual initiative, on ambition issuing in decision, on the stubborn hardening of moral muscles braced to achievement, but on suffering, endurance, sorrow, submissiveness - rage and rebellion too, often, but rebellion frenzied, futile and passionate, as unavailing as a cry of pain or an oath. ${ }^{1}$

${ }^{1}$ As in Dostoyevsky's best known novel, Crime and Punishment. 
Their people are the playthings of forces too great for them; they have dreams, aspirations, but that is all; and they drift to storm or safety, to tragedy or happiness with little will of their own.

Take for instance, one of the best known characters in Russian literature, the Rudin of Turgenev. Gifted with surpassing power of clear thought, with eloquence, with real intellectual greatness and personal charm, he remains a failure. "Nature has given me much," he says in a letter of bitter confession, "but I shall die without doing anything worthy of my powers, without leaving any trace behind me. All my wealth is dissipated idly: I do not see the fruits of the seeds I sow. I am wanting in something . . . A strange, almost farcical fate is mine; I would devote myself eagerly and wholly to some cause, and I cannot devote myself. I shall end by sacrificing myself to some folly or other in which I shall not even believe." The trouble with Rudin could be stated in two ways: he lacked the will to make decisions, to express his ideas and his ideals in constructive action, so that he drifted with the tide of circumstance, a wasted genius; and he loved perfection with the ecstatic love of a mystic - he could neither compromise nor bring his mind to bear on the patient, toilsome work needed for the attainment of his high goal - as if Christian, in the great English allegory, had let himself be so rapt in 
his vision of the Celestial City that he stumbled and perished on the perilous road by which he had to travel. It is true that Rudin himself is a type of only a small group, the "intellectuals" of the forties who felt the inspiration of western thought but lacked any outlet for their enthusiasm and failed, not entirely by their own fault, to give their country any positive help toward a higher life. But his incapacity for constructive action is nevertheless truly Russian. The Polish novelist Henry Sinkiewicz has called it l'improductivité slave, the Slavic fruitlessness. And Rudin's combination of inertia - not mental inertia but inertia of the will - with high ideals made him a genuine type. "Every Russian" says Stepniak, " has in him a bit of Dmitri Rudin."

Oblomov, in Goncharov's novel of that name, is quite unlike Rudin, but he too is a type of a man virtuous, gifted, yet with no power of initiative, of continuous action directed to a definitely willed end. The typical Russian tragedy is the tragedy of futility. Yet one need not suppose that this paralysis of the will is inherent in the Slavic character. It may rather be interpreted as a submissiveness engendered by ages of rigid rule and unbroken isolation. It was apparently the will of God that they should obey others, and to this virtue of obedience they adjusted themselves. The thoughtful ones among them might react on the 
situation with sadness or even with rebellion, but what was to be done? And the millions who knew nothing of any other mode of life were not even mutinous.

The literature of Russia is indeed a literature of almost unrelieved gloom - its sorrowful soul forever looking through bars or beating at them in vain rage. Of all the great Slavic writers Gogol alone - a child of the Ukraine, of Little Russia, a Cossack of the south, born and bred among a people of lighter heart than their brethren of the north - reflects anything of the gayety and joy of living that is a commonplace in western literature. Turgenev, Tolstoy, Dostoyevsky and their successors down to our own day paint a world full of failure, tragedy and intolerable sadness. But on the other hand the Russian people themselves are not gloomy at all. They have been accustomed for centuries to conditions that a westerner would find unendurable, and they have learned to make the best of things. It is the will of God; why should we make matters worse by complaining? It is true that this submissiveness and cheerful endurance had its evil side in a certain animal brutality, in drunkenness, in sensuality, and might break now and then in fits of ferocity and passion. But on the whole we may view the Russians as inert, uncomplaining, submissive, and yet gay and cheerful under the yoke, just as the negroes of the south sang and danced in the days of 
slavery. It seems strange, perhaps, to a free people, but there is nothing paradoxical or unusual in the gayety of slaves.

But what would be paradoxical and unusual would be a light heart among slaves who have begun to dream of freedom. The incoming of ideas from the west might not touch the millions. But to the few it meant a blinding vision of a world of liberty and progress from which they were barred, not by nature, but by a rigid, repressive and corrupt system of government. Thoughtful minds learned to feel the tragedy of membership in a race whose very soul had become paralyzed and whose government, however corrupt and inefficient in its other activities, kept a watchful eye on the chains that kept the people enslaved. The gloom that we associate with Russian literature is the gloom of this awakened few, and the more passionate of these found relief - according to their temperament - in religious skepticism, in science, in enthusiastic study of western literature, in German philosophy, or in nihilism. And the appearance of nihilism is the one exception to which we referred above, the one element in Russian literature that shows the birth of a Russian will to act. The action might be blind, foolish, and for a time fruitless, but it was the beginning of the breaking of the shell. We have spoken of the submissiveness, the spiritual inertia of 
the Russians as being their most visible characteristic, inducing a vast patience, an uncomplaining obedience, a broad tolerance and adaptiveness too, a plasticity that was the corollary of their utter lack of initiative. But after the middle of the nineteenth century we see a new spirit rising - a tiny spark at first, but flickering into a flame and finally bursting forth in our own time in the immense conflagration that we call the Revolution.

The word " nihilist" appears first in a novel of Turgenev, Fathers and Children (1862). A father and uncle, men of the old school, Nicolai and Pavel Petrovitch, are in conversation with a boy just returned from the University. The young man, self-confident, his head full of the new ideas he had picked up at college, proud of the skepticism which he had learned to apply to all things, had brought home with him a friend, Bazaroff, and he thus describes his companion to the two older men :

"Would you like to have me tell you, my dear uncle, what sort of person he is?"

"Pray do, my dear nephew."

"He is a nihilist."

"What?" asked Nikolai Petrovitch; and Pavel Petrovitch elevated his knife, with a bit of butter sticking to the blade, in the air, and remained motionless. 
IO4 RECONSTRUCTION AND NATIONAL LIFE

" $\mathrm{He}$ is a nihilist," repeated Arcady.

"A nihilist," said Nicolai Petrovitch. "That comes from the Latin nihil, nothing, so far as I can judge; consequently that word designates a man who ... who recognizes nothing."

" Say: ' who respects nothing,' " put in Pavel Petrovitch, and devoted himself once more to his butter.

"Who treats everything from a critical point of view," remarked Arcady.

"And isn 't that exactly the same thing?" inquired Pavel Petrovitch.

"No, it is not exactly the same thing. A nihilist is a man who does not bow before any authority whatever, who does not accept a single principle on faith, with whatever respect that principle may be environed."

But while this conversation was going on Bazaroff himself was off in a swamp hunting frogs for dissection. He was a medical student and was interested in biology. That is to say, if he was an enemy of conventions, customs, the church and the government a nihilist in that he bowed to no master and no principle - he was yet a believer in experiment, a believer in truth that he could see and demonstrate. As Pavel Petrovitch remarked a little later Bazaroff "does not believe in principles but he does believe in frogs."

Here then is the basal force in nihilism. Preceded by the kind of agitation for greater social freedom 
which was known in the west as Liberalism, agitation which might strive for freedom, a constitution, or even a republic, but which was ordinarily far from aiming at either destruction of all government or complete social reconstruction, nihilism sprang from the brutal repression of all criticism, all agitation even of the most insignificant kind which might threaten the existing régime. One of the earlier reformers was exiled for saying in a private letter that he had seen a policeman kill a man in St. Petersburg. No manifestation of political discontent was too small to bring suspicion and punishment. And the new force, checked and stifled in its normal growth, spread underground and became - at least in its extreme manifestations - sinister, deadly and bitter, a force essentially negative and destructive that would wipe out the whole social order and begin life again on a fresh page. Not that all nihilists would have gone so far. But the extreme revolutionary wing gave their tone to the rest, and moderate men joined with anarchists and socialists because they saw no alternative but submission. Thousands of earnest minds saw before them a definite choice between nihilism and the acceptance of a cruel and degrading tyranny. Some yielded to the "Slavic inertia" and turned their energies into lines permitted by the government. But many refused, and joined the ranks of " underground Russia." Dur- 
ing the decades of the sixties and the seventies militant nihilism grew and waxed fiercer, while liberalism faded and lost its influence. Even so radical a liberal and reformer as Mazzini would have seemed a moderate, a "reactionary," a defender of tyrants, among the terrorists of 1878 .

Yet liberalism, overshadowed as it was for a time by the impetuous ferocity of terrorism, did not and could not wholly disappear. ${ }^{1}$ The great army united for the liberation of Russia must be thought of as consisting of two sections, - three, if we distinguish the terrorists as a separate group - allied for the common purpose but likely enough to develop mutual hostility once that common purpose was achieved. Or if the word "sections" seems to imply too sharp a line of cleavage we may dismiss it and think of three modes of progress, one cautious and temperate, one impatient and passionate, a third reckless to the point of fury, three modes that shade into one another imperceptibly by infinite gradations. Moreover a liberal of to-day might be associated with nihilists to-morrow, and might even be a terrorist the day after. All desired freedom, and to the Czar all were revolutionaries, equally guilty, but they varied greatly both in creed and in enthusiasm.

Let us take a concrete example. Two of the most

1This is further discussed in Chapter IX in its application to recent years. 
notable of the earlier reformers were Alexander Herzen and Michael Bakunin. For twelve years the former was an exile in France and England, while his friend spent two years in an Austrian prison, six in the dungeons of St. Peter and St. Paul at St. Petersburg, and four in Siberia. Both had begun as radicals and socialists, but one passed gradually to the ranks of liberalism while the other became an anarchist of the extreme type. A comparison of utterances by the two men late in the sixties shows clearly the direction of the two currents that in spite of all efforts to dam them both were sweeping Russia toward Revolution, two currents - to continue the metaphor somewhat recklessly - that might well meet and create a whirlpool once the revolution was accomplished.

This first from a letter written by Herzen to $\mathrm{Ba}$ kunin:

" I will own that one day, surrounded by dead bodies, by houses destroyed by balls and bullets, and listening feverishly as prisoners were being shot down, I called with my whole heart and intelligence upon the savage force of vengeance to destroy the old criminal world, without thinking much of what was to come in its place. Since that time twenty years have gone by; the vengeance has come, but it has come from the other side, and it is the people who have borne it, because they comprehended nothing either then or since. 
A long and painful interval has given time for passions to calm, for thoughts to deepen; it has given the necessary time for reflection and observation. Neither you nor I have betrayed our convictions; but we see the question now from a different point of view. You rush ahead, as you did before, with a passion of destruction, which you take for a creative passion; you crush every obstacle; you respect history only in the future. As for me, on the contrary, I have no faith in the old revolutionary methods, and I try to comprehend the march of men in the past and in the present, to know how to advance with them without falling behind, but without going on so far before as you, for they would not follow me - they could not follow me!"

This, on the other hand, is from the Revolutionary Catechism inspired if not actually written by Bakunin: "The revolutionist is a man under a vow. He ought to have no personal interests, no business, no sentiments, no property. He ought to occupy himself entirely with one exclusive interest, with one thought and one passion: the Revolution. $\mathrm{He}$ has only one aim, one science: destruction. For that and nothing but that he studied mechanics, physics, chemistry and medicine. He observes with the same object, the men, the characters, the positions and all the conditions of the social order. He despises and hates existing mo- 
rality. For him everything is moral that favors the triumph of the Revolution. Everything is immoral and criminal that hinders it. . . Between him and society there is war to the death, incessant, irreconcilable." 1

These two men are both types, and between the two extremes of cautious liberalism and war to the knife there were multitudes whose sympathies, doubtless, were with the revolution, but who cannot be classified in any absolute way. Some were watchful but passive. Some were active but not reckless. Bakunin undoubtedly had a large following, even though comparatively few lived up to the ideal laid down in the Revolutionary Catechism. In the extreme cases we must admit that the Slavic apathy was broken in a frenzied rush to the opposite extreme. Submissiveness gave place to fierce rebellion; inertia to a wild desire for action that was perhaps akin to the hysteria born of nerve-racking torment. This tendency was far from negligible; it issued finally in the terrorist movement of 1878 and succeeding years that many western minds associate exclusively with nihilism. But just as it is absurd to associate the French Revolution solely with massacres and the decapitation of aristocrats, so it is well, as we have already indicated,

1 Both of these extracts are quoted from Rae, Contemporary Socialism, pp. 273-275 (New York, 1891). 
to distinguish, not merely between liberalism, and radicalism, but between nihilism and terrorism. Those who think of nihilists and anarchists as men and women devoted primarily to the throwing of bombs and the murder of princes would do well to consider the life and activities of such a man as Prince Kropotkin. A scientist of international reputation and a man of the most admirable kindliness and sanity, Kropotkin. became a nihilist and an anarchist. And we venture to believe that few Americans - bearing in mind the Russia of his time - can read his Memoirs of a Revolutionist without honoring both his nihilism and his anarchism.

For whatever we may think of the terrorists - the militant nihilists who responded to savage persecution by war against their oppressors - the revolutionaries of the Kropotkin type were simply men and women who deliberately set themselves to the destruction of the evil system that was crushing the life out of Russia by counteracting its poison. ${ }^{1}$ According to temperament and convictions they approved or disapproved of the terrorists, but they quite realized that the killing of officials would not alone save Russia, and they bent their efforts to the moral and intellectual education of the people. The tyranny of the government

1 See The Little Grandmother of the Russian Revolution, chapters $3-6$. 
was possible only tecause of two things - the terrible apathy of the oppressed millions and the social conventions that crushed independent thinking and living, the labyrinth of customs that made life one unending slavery. If only the apathy could be broken, if men and women could be stirred to think and act for themselves in absolute sincerity, then the chains would fall off of their own accord. It was not by killing the Czar but by the awakening of a free and manly Russia that redemption could come. If even this type of nihilism often seemed to aim at destruction it was only as if a man encased in a shell should try to burst his shell simply because that was the obvious first step. But Kropotkin quite realized that even the bursting of the shell would be vain if the man thus freed should lie unchained but bewildered, helpless, passive, or if freedom brought a mad riot of passion or an aimless running to and fro. So the work of awakening the soul of Russia must be not only destructive but educative; peasants and workingmen must be taught to read and think and taught to organize not only for rebellion but for coöperation and mutual aid.

Anarchism was to many a natural corollary of this. Government as the Russian knew it was bad through and through. That one man - merely because he had the name and uniform of a Czar, a chief of police, a soldier or what not - should be able to flog, 
imprison, exile or kill another man seemed unreasonable and wholly evil. To a nihilist this was one of the many irrational conventions that must be swept away. So he stood the enemy of government as of all the other "conventional lies of civilized mankind." To Bakunin this meant war. To Lavroff and Kropotkin war was necessary, no doubt, but a war not wholly of bombs and bullets. To them the best security against murder, meanness and dishonesty, the social ills that government was supposed - in theory - to combat, was the education that would make men hate these things, cease to be murderous, mean and dishonest in their hearts. Such an education would take time, would be a long and difficult process, but so much the greater reason for beginning at once. And in the meantime complete freedom would be infinitely preferable, naturally, to the rule of the Czar. For if people are free evils tend to correct themselves; those who are foolish or wicked are checked by public opinion; the leaven of education works slowly, but it does leaven the lump, and the gradual incoming of light to darkened minds will in time clear away the evil phantoms and foul mists born of ignorance and degradation.

Whatever doubts and questions may arise in our minds as to all this it was at least a noble and fruitful doctrine. That it often brought distortion and 
blunders no one could deny. ${ }^{1}$ But in the meantime it represented the first gropings of Russia toward something better than the old helpless and indolent submission, the old Slavic apathy. So the Russia of the nineteenth century was a Russia breaking its shell, still uncertain and divided as to ultimate aim, but intent on freedom and some kind of reconstruction. What would issue forth no man could foresee. But there were certainly many of the "breakers" who tried to see that the Russian kindliness and patience should survive when the. Russian paralysis of will should be cured, and that the new Russia - not to be created by the gift of princes or even by the legislation of Parliaments, but by the growth to manhood of the whole race - should stand on the broad base of a people free in soul, devoted to "liberty, equality and fraternity" as a matter of willing choice. And if the way was a long and arduous one, full of pitfalls and guarded by formidable giants of folly, despair and passion, yet the martyrs who in the evil days of the Czars died on the scaffold, in the dungeons, or in the Siberian mines, saw the Vision afar off, and were content to be the vanguard of a host marching to certain victory.

1 See Dostoyevsky's The Possessed for a portrayol of nihilism on its worst side. 


\section{VII}

The Russian Problem and the Revolution

"I would like in these last moments, before the great event of the years, that we should look to the end and to the immediate future, and in these last times ask ourselves, can we really do something, not in order to reach Constantinople, not in order to alter the map of Europe, but in order to save the national inheritance, an heirloom from the past which has fallen into our hands."

These words were spoken by Alexander Fedorovitch Kerensky on the floor of the Imperial Douma of Russia a month before the abdication of Nicholas II. They state the essential problem of Russian reconstruction, a problem which two anxious and discouraging years of revolution have in no way altered. Different leaders, different parties have given their various interpretations and have added this or that social gospel. But all hope that from the chaos will emerge a new Russia, her national inheritance preserved and liberated, the obstacles and handicaps to her progress discarded. It is our task to make the efforts toward this 
end intelligible, to face the confusion and turmoil of the revolution and seek to clarify and simplify the course of events by isolating the essential facts. Much that is doubtful and bewildering will remain, but we may at least peer a little way through the smoke of battle and map out such guiding points as may help toward the comprehension of strategy and issues. For as Kerensky himself pointed out in another speech revolution is only destructive as a means to an end; it is constructive in its ultimate purpose, and only when it fails does it result in disorder and retrogression. Our effort must be to see the essential aims in the Russian revolution, the struggles to form a solid basis on which reconstruction may go forward.

We have already seen part of what Kerensky had in mind when he spoke of the Russian " national inheritance." Let us see now the present phase of the revolution in the light of past phases, placing before our minds for the sake of clearness the outward expressions of the revolutionary spirit in its ebbing and flowing during the last hundred years. The most obvious landmarks may be indicated by their dates 1825, I86r, I881, 1905, and I9I7, and in I9I7 the three months of March, July and November.

In 1825 the influence of the French revolution and of western liberalism moved a group of reformers known in later discussion as Decembrists - to take ad- 
vantage of the death of Alexander I and the accession of Nicholas I by agitating for the enthronement of Nicholas' more liberal brother Constantine and the proclamation of a constitution. The movement was easily suppressed and the leaders executed or sent to Siberia. There followed a period of ferocious repression that ended only with the death of Nicholas in 1855 . His successor, Alexander II, gave promise of something better, and for a time this promise was realized. The law courts were improved, the persecution of liberalism was relaxed, and two great reforms were carried through, the emancipation of the serfs (I86I) and the creation of local elected assemblies - Zemstvos for the country districts and Doumas for the towns. Both reforms were imperfect: the liberated serfs, saddled with a heavy debt for the purchase of their lands and often economically if not legally at the mercy of their former proprietors, found themselves frequently worse off than before, and the Zemstvos and Doumas were soon almost overwhelmed by a wave of reaction. But notwithstanding the gradual fading of the Czar's liberalism something was gained. It was difficult for the peasants to escape from economic dependence, but from their old legal bondage as serfs there had been no escape at all short of flight and outlawry. The Zemstvos and Doumas might be shorn of their power and the electorate might be limited, but they provided 
at least some medium for the expression of a will other than that of the government.

It has always been true that the concession of some liberty leads to a vigorous demand for more. The real revolutionary agitation in modern Russia began in the sixties and became steadily more powerful in each decade thereafter. Nihilism had existed, no doubt, in the forties and the fifties, but it was largely a speculative and intellectual movement, ineffective in action and carrying no formidable threat against the existing system. But as Alexander II abandoned his movement for reform and relapsed to the repressive policy of his father, the disillusioned party of liberty took up the cause with renewed activity; their anger burned away what was left of their indolence; and without throwing aside their dreams they turned to action. Denied the legal right to freedom of speech, even to petition or to educate, the more determined ones declared war, and took to the only weapons left to them, the revolver and the bomb. So elusive and powerful did the invisible army of " underground Russia" become that the Czar almost yielded, and he was planning to give Russia a constitution when he was assassinated in $\mathrm{I} 88 \mathrm{I}$.

As after I825 and I86I, the forces of reaction and persecution became fiercer than ever after the murder of Alexander II. During the reigns of Alexander III 
(I88I-I894) and of Nicholas II (I894-I9I7) the world saw Russia divided between two powers. One was the visible authority of the Czar and his officials, backed by police and army; the other was the invisible but ever present and ever growing host of the Revolution. It was the same situation that one might have seen sixty years before in the Europe of Metternich and Mazzini. But even Metternich did not dare to crush and trample with the brutal thoroughness of the Czars; nor did Mazzini and his companions ever respond to persecution with the ferocious pertinacity of the terrorists. Then came the Russo-Japanese war of 1904. The defeated machine of Russian government, discredited and dismayed, broke before the attack of an indignant people, and the revolution won a decisive victory with the granting of a constitution in 1905. But it was not final. The autocracy was humiliated and defeated but not beaten, and little by little it seemed to be winning back its power. The end came after the betrayals and the disasters of $1915^{-1}$, and the abdication of the Czar in March, I9I7, left Russia a republic. But a republic without charts or rudder, and the anniversary of the Czar's abdication saw the country broken, disunited, insulted and robbed by the triumphant Germans. Russia had passed from autocracy to something very like anarchy. ${ }^{1}$

1 It is worth noting that each of Russia's great wars since 1850 
So much for the historical landmarks. Now let us make another step toward clear thinking by noting one or two significant facts as to territory and population. In the first place we must bear in mind that nearly all of the current statements regarding the Russian people refer to only one section of Russia, the section known as Great Russia - roughly speaking, the northern half of European Russia, not including Finland, the Baltic provinces, or the sub-arctic regions. This was the older Russia; in it lay the three cities that were the successive seats of government before the founding of St. Petersburg - Novgorod, Kiev and Moscow; it was, in fact, the nucleus of the Russian Empire. But the colossal empire of a I9I4 map covered far more than Great Russia, and it is perhaps the map with its uniform coloring that deceives us sometimes into thinking of the people governed by Nicholas II as homogeneous, all Russians. The truth is, of course, far otherwise. Something like a hundred millions of the population of the Empire were not even Slavs.' The Russia of the Czar was a vast, com-

has seemed to bring about a political crisis. The Crimean War of $1854-6$ was followed by the reforms of Alexander II; the Russo-Turkish War of $1877-8$ was followed by the activities of the terrorists and the murder of the Czar; the war with Japan was followed by the forced concession of a constitution; and the Great War brought on the final crisis of 1917. It was as if the rigid, artificial machinery of state could never meet a severe strain without cracking' and threatening collapse. 
plex mass held together solely by the military power of an autocrat. Within its area of over eight million square miles it is estimated that 103 languages were spoken. The Turcomans of the Trans-Caspian desert, the Georgians of the Caucasus, the Tartars of the Volga, the Poles of Warsaw, and the peasants of Great Russia were as radically different in race, traditions, religion, customs and tongue as Mexicans and Americans, Spaniards and English. To millions of these no study of the spirit or destiny of Russia will apply simply because they were part of Russia only by an external bond, common subjection to the Czar.

The economic cleavage of population was not so profound but it was far from negligible. Eighty to eighty-five per cent of the Russian peoples, both in Great Russia and the provinces, were and still are peasants, agriculturists, intensely conservative, submerged in the Russian apathy, ignorant, patient and submissive, indifferent or hostile to the Revolution in all of its phases except one, the matter of the land. Only among the workingmen of the towns, the students of the Universities, the more liberal sons of the landed nobility ${ }^{1}$ and the professional classes can we

1 This may occasion surprise among those who view the nobles as invariably narrow and moved by class feeling, but it need not. Tolstoy, Kropotkin and Catherine Breshkovsky, to name the three revolutionists best known to Amęicans, were all "aristocrats" by birth. 
expect to find signs of real intellectual movement, and it is in this numerically small group that we must look for the spirit of the Revolution.

It is true that the revolutionary leaders spoke with enthusiasm of the "people," based their hopes on the peasants, and often regarded the village Mir - the democratic commune of European Russia - as the ideal community of the future. But it was almost impossible for the most earnest of the missionaries of the revolution to move the peasantry to action. Nothing in the story of modern Russia is more tragically amusing than the account by Catherine Breshkovsky, the "little grandmother of the Revolution," of the effort of the reformers to stir the sluggish souls of the " people." 1 Many of the leaders deliberately accepted the conclusion that education was more important than revolt, and that a long period of slow and difficult educational agitation must precede any successful attempt to make Russia politically free. Others simply put the peasants to one side in their immediate calculations and resolved to depend solely on the educated minority, to free Russia by revolution and trust to the future for the political and spiritual emancipation of the peasants. "You," wrote Turgenev to some of the enthusiasts, " are supposing that revolutionary or reformatory ele-

1 The Little Grandmother of the Russian Revolution, chapters 4 and 5 (Boston, Little, Brown \& Company, 1908). 
ments exist in the people. In reality quite the opposite is true. Revolution - in the true and concrete meaning of the word; I might say, in the largest meaning - exists only in the minority of the educated class; and this is quite sufficient for its triumph, if only we do not extirpate ourselves by our mutual quarrels. . . . The rôle of the educated class in Russia is to transmit civilization to the people, in order that they may themselves hereafter decide what they shall accept or repudiate." But in the meantime the people themselves, or at any rate the peasantry of over one hundred million souls, "are conservative par excellence; in their sheepskins, their warm and dirty hovels, they foster the germs of a bourgeoisie which will leave the illfamed western bourgeoisie far behind." It is the old story of all peoples, that advance and redemption are the work of the few, and that if the work be well done the many, in the fullness of time, reap the reward.

The student of modern Russia must then do three things. He must first frankly recognize the complexity of the whole problem. Then he must fix firmly in his mind the external landmarks which we have indicated above until such dates as I86I, 1905, I9I 7 bring an instant and exact association with definite events. And finally he must forget the deceptive word " people," regard as distinct elements in the situation the peasants, the proletariat or wage-earners, the business 
and professional classes, and concentrate his attention on the one dynamic element in modern Russia, the Revolution. So far as we are concerned the history of recent times means the history of the movement that began in the liberalism of 1825 , brought about the emancipation of the serfs and the creation of zemstvos and doumas, became at once broader and more intense in the sixties and seventies as nihilism, developed after I 878 the fierce aspect of terrorism, took to itself the - lessons of Marxian socialism after 1883 , finally overthrew the autocracy, and then parted into battling factions after the victory was won.

We shall confine our view then to Great Russia and to the small but intensely alive minority there who aimed through weary years and decades at the redemption of their country through revolution. If the revolution should overturn Czarism the outer rim of the Empire might be expected to drop away - temporarily at any rate - and form independent states, Poland, Finland, Ukraine, Georgia, the units of Central Asia, Siberia and the rest, each to work out its own salvation. They might ultimately form a federal state, as loose as the British Empire, as close as the United States of America, or they might not. But in any case they are not our immediate concern; the possibility of a free federation of all the sections that once made up the Russia of the map is for the future to determine. For 
the moment we must regard the provinces as separate problems and concentrate on Great Russia, the nucleus around which the whole heterogeneous empire had been built.

For Great Russia was a natural unit which would probably stand or fall, become free or remain enslaved, as a single social group. Of its population of about sixty millions ten per cent might perhaps constitute the revolutionary element, though this is little more than a guess. The rest were either indifferent or loyal to the existing régime, and of these the indifferent, the passively loyal, included nearly all the peasants, the vast majority of the population. Not that the peasants were contented. They were not. But their sole interest was in secure possession of their land, not in political change; they blamed their ills on landlords, agents, officials and the like, not on the Czar; and their longing for relief from their burdens was inarticulate, blind, undirected to any program of action. The actual burden fell on the few who saw - some clearly, some dimly - the vision of a free Russia, and who were resolved to make it a present reality.

These, varying greatly in their intensity of conviction, in their honesty of purpose, and in their beliefs as to the paths to be followed, may be grouped in three main classes: the liberals, the anarchists, and the socialists. Of these the anarchists, a great force in the 
nihilism of thirty and forty years ago, had ceased long before I9I7 to be a considerable element in the revolution. We may, perhaps, ignore anarchism therefore, and consider liberalism and socialism as the two great forces that have moved Russia during recent years. Remembering, however, that they are both only an expression and a formulation of something infinitely greater than either - the passionate desire for liberty. In the breasts of peasants, factory workers, merchants, students, of every thinking Russian indeed except the Slavophils and those whose interests or whose prejudices bound them solidly to the autocratic régime, surged the yearning for relief from an intolerable burden. Often the burden was felt merely as a physical one and was purely economic a tyranny not clearly localized or diagnosed but involving actual hunger and suffering. Often it was a spiritual one, the forbidding of normal and compelling intellectual, social or ethical activities. Often it was a generous resentment at the sight of good men and women sent to prison or to Siberia, of innocent people shot down or tortured. Often it was negative, hardly at all constructive. But with all its varieties of motive and aim it was fundamentally a movement of oppressed humanity against an inefficient, brutal, irrational machine, and it did take the two main forms of liberalism and socialism. 
To one who has studied the liberalism of western Europe the liberalism of Russia - active in 1825, dormant for fifty years, then active again towards the end of the Igth century - is not difficult of comprehension. The liberal may be ready to recognize that many of the evils from which the people suffer are economic. He knows that there is wretchedness and degradation in America and England notwithstanding their free institutions. He may admit to the full the contention that there are deadly ills in society that have apparently little or nothing to do with politics. And he may even admit that private ownership of land and capital has something to do with social ills and may well be examined, placed under restrictions, perhaps be limited or abolished. But he is primarily interested in the securing of politcal liberty. Once the state is made essentially democratic, once government of the people is firmly established, once freedom from arbitrary imprisonment, arbitrary taxation, arbitrary legislation and an irresponsible executive is definitely secured, then social reforms may be carried through according to the wish of the sovereign people. Political liberty is the foundation stone. Without it nothing permanently good is likely to be achieved, welcome as the isolated good deeds of an autocrat - such as the emancipation of the serfs - may be. With it an infinite degree of progress becomes possible. 
Moreover political liberty is a fairly definite and specific thing on which all may agree and which the experience of America and western Europe has shown to be perfectly feasible. Social reform, on the other hand, is a slow and difficult matter, and a social and economic revolution is formidable beyond anything the human race has yet attempted - formidable not only in its inherent difficulty and complexity but in the fact that many good and wise men are opposed to it, perhaps even the majority. To defy a tyrant and to substitute for tyranny government by the people is a matter in which all may unite; but to defy one's own loyal comrades in the midst of the battle and to excite disunion and internal dissensions while the struggle is still going on is unwise. Liberalism, therefore, aims primarily at political liberty - government by the people.

Now the Czar who had emancipated the serfs, Alexander II, had also instituted popular representative assemblies, the Zemstvos in the country districts and the Doumas in the towns. These had been so restricted both as to electorate and as to power that they came to be of little significance in actual government. Still they provided a starting point. All that needed to be done was to make these bodies really representative, to give them a large local power, and to institute a similar assembly - an Imperial Douma - that would rep- 
resent the whole people. Then with these local and national popular legislatures and the erection of an executive responsible solely to the people or to the people's representatives, liberty would be assured. Thereafter social reforms would be in the hands of the people, and could go on as they go on in America, England or France - too slowly for the impatient, perhaps, but keeping pace with the desires and progressive enlightenment of the nation. This program could be entered upon, if such seemed desirable, even with the Czar on the throne. England and Italy have kings, and the most far-reaching of the reforms of the French Revolution were carried through between $\mathrm{r} 789$ and I792, while Louis XVI was still king of France. Or a republic could be organized. The matter of monarchical or republican form was a detail and not a fundamental one. The essential thing was to place the actual government in the hands of the people, to remove the intolerable burden of arbitrary and irresponsible rule, to achieve liberty.

In this spirit the Revolution of 1905 was begun and carried through. It was to a great extent a failure. It did see the creation of an Imperial Douma, but the executive machinery and the bureaucracy remained beyond popular control, and the Douma between 1907 and I9I7 was an empty form, a debating society, potentially of immense value but devoid of actual power. 
It was in these years that the government of the Czar was proved incurable, - rigid, faithless, corrupt and blind. So in March, I9I7, the Revolution reached its second phase; the Czar abdicated; and from March to July the government of Russia was in the hands of liberals supported by the moderate socialists. ${ }^{1}$ Then a third wave of revolution in July swept the liberals from power; the great socialist leader Kerensky became head of the government; and he in turn was overthrown in November by the more extreme group known as Bolsheviki. Socialism had supplanted liberalism at Petrograd.

And when we say socialism we mean Marxian socialism. As we use the word in ordinary careless speech it is apt to mean almost any movement that seeks to abolish distinctions of class and wealth. If we use it more carefully we mean, usually, any move-

1 In this first Provisional Government the best known figures were Prince Lvoff, the Premier, Professor Miliukoff, Minister for Foreign Affairs, Gutchkoff, Minister of War, Tereshtchenko, Minister of Finance, and Kerensky, Minister of Justice and then after Gutchkoff's resignation Minister of War. Kerensky was the link between his colleagues and the Radicals of the Council of Soldiers' and Workmen's Deputies.

For the most part we have still to rely on periodicals, notably the New York Times Current History, for such knowledge as has been available for the iast two years. But there are three interesting and informing narratives that taken together give a connected story of the successive phases of the revolution, Marcosson's Re-Birth of Russia, Ross, The Russian Upheaval, and Ernest Poole, The Dark People. 
ment that will bridge the gulf between labor, on the one hand, and capital and land on the other. We think of the familiar argument that labor really produces all wealth, but that labor is helpless without capital and land; that consequently labor is the slave of capitalists and land holders; and that the correction of this evil a far more fundamental evil than any merely political tyranny - is the great social problem of the present and future. In a general way this is a reasonably true conception of socialism. But as to the actual means of realizing this aim socialists have been far indeed from agreement, and the dominant socialism of to-day is that which has followed the leadership of Karl Marx. We have already indicated the nature and development of Marxian socialism in Germany. We have now to see what it means in Russia.

It will be remembered that the reforming movements of 1825 to $I 86 \mathrm{I}$, the nihilist movement after I866, and the terrorist war of assassination that began about 1878 were all movements of no single creed. They were inspired largely by the great spiritual forces that were stirring England, France, Germany and Italy, and they aimed at the attainment of liberty whether by the education of the masses, by painfully won political and social reforms, by the killing of Czars and chiefs of police, by the centering of all functions of government in the Mir - the village com- 
munity - or by anarchism, the total destruction of all government by armed revolution. Their leaders were men like Herzen - a socialist of the older type who would be content to go slowly, keeping, as he said, "one step ahead of the people but not two steps"like Lavrov or Kropotkin, educational anarchists who believed in missionary work that would gradually bring the people up to the necessary level of enlightenment and initiative for the realization of a stable and wise freedom - and like Bakunin, a revolutionary anarchist who would clear away in one wild conflagration all the accumulated rubbish of laws and governments and go back to a "state of nature." And there were all degrees of radicalism and passion from Bakunin and the terrorists to the thoughtful but passive ones who despised the existing power and sympathized with the malcontents but who could not make up their minds to action or who feared the tempest that a successful revolution would let loose. All of these were in agreement as to criticism, as to negation; but as to the path of positive advance they differed greatly, their doctrines only resembling one another in their " utopian" idealism.

But in the years after the murder of Alexander II, i.e., during the reigns of Alexander III and Nicholas II, Marxian socialism began to filter into Russia. Anarchism and communism gradually lost their hold. 
Professor Miliukov could say in 1905 that "no anarchism exists in Russia." It had had its day when the only hope of a desperate people seemed to lie in destruction. Not that philosophical anarchism has not its constructive side. It has. But it is not the side that appeals to the average man simply because its Heaven is a distant one, to be attained by labor, education and self-restraint. To most of its disciples anarchism has always meant destruction and little else, a most natural and human war-cry when one is smothered and tortured by a powerful and deadly force, but not a permanent ideal. So that Marxian socialism with its collective ownership of land and capital provided just what anarchism and communism lacked a logical, scientific basis, a definite, constructive program, liberation from both economic and political oppression, a golden vista of a road to the heights that was solidly based - it was thought - on reason and facts, that was free, orderly and final. And it had a clear and compelling slogan: "Workers of the world, unite!"

So anarchism faded away. The older socialism of the commune became out-of-date. Those of the revolutionaries who felt that, whether Marx was right or wrong, social reform should be postponed and a democratic state achieved before anything else was attempted gathered in the liberal party of the Constitu- 
tional Democrats or Cadets, and with these went many of the older warriors of the cause, the enemies of the Czar rather than of the capitalists. But the more impassioned radicals adopted the Marxian doctrine with enthusiasm. The strength of the Cadets lay in the professional and business classes, the bourgeois; the strength of the socialists lay in the proletariat of the towns; and holding aloof from both parties stood the great mass of the peasants with their one political creed and demand, the land to the cultivator.

Early in the revolution it became evident that the socialists were likely to dominate the situation. And then appeared the familiar conflict between extremists and moderates. There was little or no disagreement between, let us say, Kerensky and Trotzky as to the ultimate goal. Both believed in the socialist state. But Kerensky, like Marx himself and like the majority of Social Democrats and Social Revolutionaries throughout the world, regarded the attainment of the socialist ideal as a matter of organic growth, no more to be realized in the twinkling of an eye than a child becomes a man over night. Thus, for instance, there was universal agreement as to the redistribution of the land. But even Kropotkin, anarchist as he was, agreed with the moderate socialists in regard to the complexity of even so necessary a reform and advised against haste on the grounds that it would mean confusion, in- 
justice, and infinite quarreling. One may condemn a cancer and may also condemn its removal by one sweep of the knife. But to a certain temperament such hesitancy smacks of treason, and it is always easier for the impatient fanatic to win the applause of an undisciplined multitude than it is for one more cautious.

From the outset of the revolution the Council of Soldiers' and Workers' Deputies - practically all extreme socialists or Bolsheviki - were a thorn in the side of the Provisional Government and the Douma. The Council represented the proletariat, not the people, and it had all the fury and fanaticism of the Jacobin Club, with the same fervor for a gospel that was to bring confusion to tyrants, i.e., the bourgeois, and a golden age to the faithful. Its leaders were advocates of immediate and radical reconstruction on, socialist principles. Their fierce enthusiasm led first to the retirement of the liberal ministers of the Provisional government, then to the retirement of Kerensky, then by a pathetic irony to the exile of men and women who had suffered under the old régime, who had borne for years the burden of the revolution, and who were now spurned by the wild ardor of those who reaped where others had sown.

And so we have Bolshevist Russia, a marvel and a portent to the world throughout I9I8, crumbling now and perhaps to give way to a new phase before another 
month is past, but still dominant in Petrograd as these words are written. Here is part of its platform: ${ }^{1}$

I. To effect the socialization of the land, private ownership of the land is abolished, and the whole land fund is declared national property and transferred to the laborers without compensation, on the basis of equalized use of the soil.

2. The Soviet law of labor control and the Supreme Board of National Economy are confirmed, with a view to securing the authority of the toilers over the exploiters, as the first step to the complete transfer of all factories, mills, mines, railways, and other means of production and transportation to the ownership of the Workmen's and Peasants' Soviet Republic.

3. The transfer of all banks into the ownership of the Workers' and Peasants' state is confirmed, it being one of the conditions of the emancipation of the laboring masses from the yoke of capital.

4. With a view to the destruction of the parasitic classes of society and the organization of the national economy, universal labor service is established.

5. In the interest of securing all the power for the

1 Taken from the Nation (New York) of December 28, I9r8. These paragraphs are contained in a resolution submitted by Lenine and Trotzky to the Constituent Assembly that met January 18,1918 . The Assembly proved to be hostile to Bolshevik rule and was dissolved after one stormy session. 
laboring masses and the elimination of any possibility of the reëstablishment of the power of exploiters, the arming of the toilers, the formation of a socialistic red army of workmen and peasants, and the complete disarmament of the wealthy classes are decreed.

It is a document well worthy of careful study, apart altogether from our opinions as to the validity of its principles. German in its origin, the program is absolutely Russian in its mysticism, in its adoration of a light that dazzles and fascinates - sadly Russian moreover in that the light came from the west, and that its alien beams lit only the spiritual mountain tops, leaving in darkness the brutal facts.

For the Germans were in Poland and Riga, and there were a hundred million people in Russia to whom the " class war," capitalistic tyranny, the emancipation of the proletariat were words without meaning, who cared nothing for votes and seats in Parliament, and whose sole desire was land to cultivate and the opportunity to live in peace.

As these pages go to press Russia is still torn by factions, and Poland, Great Russia and the Ukraine are in the agony of a civil war that may be ended or may be embittered - we can only hope the former by the allied army of intervention that is fighting its 
way toward Petrograd. Whatever be the outcome of these turbulent and wretched months, the issues will remain between the moderate socialists, the Bolsheviks, and the liberals, for the peasants as a whole are of no party and desire only peace. Bolshevism is probably only a phase and a passing one. It is simply socialism consumed with a human but futile passion for immediate realization. As to socialism itself one hesitates to make any absolute pronouncement, but it is permissible to express an opinion. To say that it is German, not Russian, is true but not particularly significant; it is unfortunate, perhaps, but certainly not disastrous that Russia has often owed her ideas to the west, is facile in borrowing and adapting. ${ }^{1}$ It is more significant to point out that the Marxian gospel is essentially a gospel for a highly industrial society. Marx wrote Das Kapital in England, and he himself believed that England, the workshop of the world, was ripe for his doctrine beyond any other country of his time, while of Russia's 180,000,000 possibly ten per cent are real proletarians. As has often been remarked the Russian temperament and tradition is in its own way intensely democratic, but it is not particularly Marxian. Tolstoyan anarchism is infinitely more

1 "We Russians have chosen to live on other people's ideas, and we are saturated with them," says a student in Dostoyevsky's Crime and Punishment. 
truly Russian than is socialism, and even orthodox socialism in Russia would, one suspects, become its own antithesis, government by the few - and those few not the workers. So that even the more moderate forms of socialism would seem to be alien and academic, little related to the national life of Russia.

Whether the present disorder will lead to reaction, or whether foreign intervention will produce new diseases, or whether the fervor of 1918 will insensibly die away into some workable scheme, socialistic or otherwise, remains to be seen. It would indeed be a daring prophet who would venture to forecast the progress of events during the next year or the next month. The poetic mysticism, the uncompromising idealism, the noble sincerity that are the outstanding characteristics of the Russians, the immense patience, ignorance, credulity and conservatism of the peasants, the lack of traditions - whether inspiring or confining - that might guide and balance in the building of a free political structure, render one doubtful in applying any parallel from the revolutions of the western peoples. It was perhaps inevitable that Russia should face the colossal problem of social and economic reconstruction before political liberty was assured and while the Prussian invaders were burning and slaughtering within a few days' march of Petrograd. Russia is nothing if not unpractical. Yet it is one of the most 
amazing and most pathetic spectacles of history to see a Mary among the nations, to adopt Stephen Graham's parallel, ${ }^{1}$ facing a task that might well daunt the most capable and efficient of Marthas. When we doubt the ultimate success of socialism in Russia it is not because we are condemning socialism itself; it is because a people so far conspicuously lacking in the gift of practical organization should attempt the most tremendous task of social reconstruction ever attempted since the world began.

Yet we of the more practical west may stand in amazement, perhaps, but in some reverence too before a people who have dreams that they willingly die for, whose idealism may fall away from unworthy leaders but may be trusted to flame again in its never ending passion for final truth, for divine perfection - an idealism infinitely less practical than that of clearthinking France or of scientific, well-disciplined Germany. It is the naive and childlike faith of Russia, the impossible simplicity of Ivan Durak, "to the Jews a stumbling block and to the Gentiles foolishness," that confounds us and makes us hesitate to apply our ordinary standards of judgment.

After all the essential fact is that Russia is awakening. Even the humblest peasant prizes his newly won

${ }^{1}$ Graham, The Way of Martha and the Way of Mary (New York, 1917). 
and still insecure freedom, little as he cares what government holds sway at Moscow or Petrograd. And if Russia is still bewildered, easily deceived, prone to trust others, yet the Slavic apathy is breaking, and the wings of her idealism may carry her to heights beyond the power of our firmer, more cautious climbing. The supreme prophet of Russia may have uttered the allegory of his people in words that he applied to himself : "There are men with powerful wings whom pleasure leads to alight in the midst of the crowd, when their wings are broken; such, for instance, am I. Then they beat their broken wings; they launch themselves desperately, but fall again. The wings will mend. I shall fly high. May God help me!" 1 So with Russia. The wings will mend. She will fly high. May God help her!

1Tolstoy's Journal, October 28, 1879. Quoted in Romain Rolland, Tolstoy, pp. 306-307 (New York, I9II). 


\section{VIII}

British Liberty and the Empire

OF all the countries of Europe England is apparently least in need of radical reconstruction. It has become a truism to say that her history is the history not of sudden and dramatic changes but of slow and cautious advance. The foundations of her political structure are so deeply and firmly laid in the experience of a thousand years that no shock seems likely now to overthrow it. But Britain's political stability does not mean political rigidity, nor does it involve freedom from national problems of the first magnitude. The impression that we have of a certain security and placidity in England is partly a just one; the solidity and elasticity of her governmental organization, the ease and steadiness with which her constitution has met every shock, developing by constant readjustment, both reflect and react upon the British character. But the words solidity, elasticity, readjustment are used advisedly. If solidity is our first impression elasticity is the second. It is not quite true that there have been no revolutions in English history, nor is it certain that 
there will be none in the future. The instructive thing is not the absence of dramatic moments and of crises but their character and their outcome. And the study of these crises in the past is the surest way in which to see both the basis on which British liberty rests and the way in which present and future problems both of freedom and of empire are likely to be met.

Let us take our stand first at the period of the American Revolution. "The body of this people," wrote Benjamin Franklin of the English in I769, "is of a noble and generous nature, loving and honoring the spirit of liberty, and hating arbitrary power of all sorts." The observation was a true one, and this spirit of liberty, this hatred of arbitrary power was based on specific and definite facts. Actual liberty is always a matter of compromise; in the freest lands of the twentieth century there are miscarriages of justice, restraints of freedom; but in the main it is true that in eighteenth century England arbitrary imprisonment, arbitrary taxation and arbitrary legislation were things of the past. Moreover the government was directly and absolutely responsible to Parliament, and the dominant House of Parliament, the Commons, in theory at least represented the English people. Much remained to be done, assuredly, before England could be called a democracy, but much had been achieved. 
And it had been achieved by definite steps in a slow but unbroken progress.

The traditions of English liberty went back to Alfred the Great; back indeed to the unrecorded ages before the English came to Kent. George Washington and William Pitt alike could look back to the ancient custom by which every township was governed by its town meeting, by which every hundred was governed by its assembly of delegates from the towns, and by which every county was governed by its folk-moot, a representative council made up of elected deputies from the towns and hundreds. The national council of Saxon England was indeed an assembly of nobles, but in every shire the machinery of self-government and much of its spirit remained intact from the half-mythical age of Hengist and Horsa to the time of Edward the Confessor. English liberty was not always actual in those days but it was a vital and stubbornly held tradition, and a tradition partly expressed in law and fact.

Then came the Norman Conquest. Like all military conquests it had its brutal side, meant shock and violent readjustment. But it consolidated England nevertheless, and by virtue of the clearer issue between foreign kings and barons on the one hand and the people on the other it led to a crystallizing of the old tradition of freedom. The vague notions of liberty were 
expressed in the desire for a re-affirming of the laws and customs of Edward the Confessor, and this was conceded by the Norman kings - not unwilling to secure the grateful loyalty of the English as a check to the lawless pride of the wolves in armor who regarded the land as booty and the king as little more than the leader of the pack.

But freedom of person, security of property, and the exercise of even a small degree of local self-government were held by a slender and insecure tenure.' The obvious need was for some definite progress toward protection from arbitrary power and a real share in the government. The former was gained when the Great Charter was signed in 1215; the latter when Simon de Montfort summoned a House of Commons in 1265 and more permanently when Edward I called representatives of the towns to sit beside the barons in the - Parliament of I295. These gains were far from final, but they represent a long step forward nevertheless. The Charter gave England a standard and a definition of liberty that was never wholly forgotten; and the representation of the towns in the national assembly was the beginning of the progress that was to lead in time to the democracy of the twentieth century. There still remained the confirming, the solid establishing of these "rights of Englishmen," the securing for the House of Commons of not merely a share in govern- 
ment but control, and the making of Parliament the true voice of all England.

The attainment of the first of these was safely determined by the Revolution of the seventeenth century. It was four hundred years after Magna Carta before the English towns were ready to assert with confidence and conviction their right to the only possible secure foundation for personal liberty - a controlling share in government. The feudal lords had been long since shorn of all their powers except those still held by the House of Lords. The seventeenth century conflict was not with the nobles but with the Stuart kings and their assertion of a right to govern independently of the nation's will. The result was decisive. After I688 the Parliament governed England; in Parliament the House of Commons was the controlling partner; there was no taxation or legislation without the consent of the national assembly, no imprisonment or punishment without fair trial before judge and jury.

One further step was needed to make the Revolution complete, and it was taken before the century of Hampden and Cromwell came to an end. This was the definite determination of the responsibility of the king's ministers to Parliament, the creation of what is known now as the Cabinet system. Thereafter the king, according to his personal qualities, might be an influence but ceased to have any direct power. His 
ministers were practically a committee of Parliament. The loss of the confidence and support of the House of Commons meant the resignation of the entire cabinet, its reconstruction or replacement. It might be possible indeed for kings or statesmen to thwart the will of the nation by manipulation, by schemes analogous to the shifty devices of the modern "boss." And this was a very real danger, illustrated only too well in the period from the accession of George III to the treaty that acknowledged the independence of the American colonies. But this is a danger against which even democracy is not secure, a danger not acute so far as kingly power is concerned since 1783 but far from removed even yet in its other aspects, removable indeed only by the growth of popular intelligence and initiative. Recognizing this, the fact remains that the perfecting of the cabinet system of responsible government made the House of Commons the ruling power in England.

So that when Franklin spoke of the English loving the spirit of liberty and hating arbitrary power he was thinking of a tradition and a fact whose origin could be seen a thousand years in the past, which had been steadily developed until personal liberty and a large measure of self-government had been attained and the arbitrary power of the king buried beyond any hope of resurrection. But Parliament was not yet the voice 
of the nation. The English people had yet to make their national body truly representative. And closely associated with this next step forward was the need not only for radical institutional reforms but for a more thorough spiritual and practical adjustment of the people to their growing responsibilities, a progressive escape from narrow insularity, a more perfect reflection in the government of the steadily developing national idealism and national conscience.

For the government of England in the eighteenth century was government by a small group; it was not truly national in any organic sense; it might be directed well or ill, with regard to national aims and ideals or with regard to the interests of a class or an individual; it might be guided by a Chatham or a Newcastle, might bring the country great glory or profound humiliation according to the accident of the ruling personality in the administration. That is to say, it had the merits and the defects of an oligarchy. And if it is true that the basis of the government had to be widened it is also true that the nation itself had much to learn before it could wisely undertake the responsibility of selecting and judging its rulers. The problem of the future was then threefold - the nationalizing of Parliament, the reform of the entire machinery of government to adapt its working to changing national standards, and the political education of the nation as a whole. 
The first of these was solved by a series of reforming measures that began with the Reform Bill of 1832 and closed with the franchise act of March, I9I8. So far as human devices can accomplish it the government of England is now the expression of the English people. The whole matter was carried through with characteristic caution and with characteristic refusal to base the extension of the suffrage on any general principle of universal right. There was no recognition of any abstract and inborn right to vote, and if any reformer had proposed such a recognition in 1832 or in the debates on Disraeli's Reform Bill of I 867 or Gladstone's Bill of 1884 it would have been unanimously voted down. Each step forward was taken on its own merits, the vote being granted on the basis of ability to use it with intelligence and responsibility. And the very slowness of the advance, with its discussions and agitations, aided in the matter of national education in government. The result is that notwithstanding its monarchical form and its House of Lords England is to all intents and purposes a democracy.

Of the whole complex process of administrative reform and the growth of political intelligence we need notice only the general trend. The essential thing to remember is that British liberty and British conception of social order, like the Empire, have been unplanned, unsystematic, unsymmetrical in their growth, not pro- 
ceeding on logical or consistent principles but moving sometimes rapidly and sometimes slowly, removing one abuse and leaving another untouched for a generation, the light coming not like the dawn, diffused and universal, but in brilliant rays that illumine a narrow circle and leave vast areas in darkness. We grow in the same way as individuals, developing wonderful skill in some things, remaining clumsy and inept in others, growing in wisdom and in stupidity, in virtue and in weakness, threading our way through a wilderness with patience and courage, to stumble and lose ourselves on the well-lit highway. But progress has not been wholly haphazard and blundering; with the erratic gleams there has been the slow advance of a real daybreak; and there has been an increasing willingness to throw down barriers, to let freedom of speech, freedom of thought, the mighty educative forces of the press and of unhampered intercourse aid in the oncoming and penetration of the light. There has been even an effort to remove economic burdens, to recognize the need for mutual help, a realization that education and reform proceed as much by the dissolving of prejudices, by the following of generous impulses, by resolute courage in magnanimity as by the acquiring of knowledge or by external changes.

We do not use the word education in the technical and institutional sense. Public education through the 
schools has indeed been systematized and democratized only in our own time by the Education Bill of I9I8one of the cases in which an obvious and inevitable reform was postponed by class, academic, and ecclesiastical opposition. But the admirable measure that has been at last enacted is the formal and institutional result of a widening of horizon, a growth of intellectual and spiritual life that altered the outlook and deepened the humanity of the English people long before it found expression and satisfaction in law and machinery. Its pioneers were men like Carlyle, Ruskin, Morris, the Arnolds, and Kingsley, and the result may be seen in the whole tone of novels and periodicals from Dickens to Galsworthy, in the immense vitality of the Labor Unions, in the iconoclastic writings of $\mathrm{H}$. G. Wells, George Bernard Shaw and G. K. Chesterton, in the " socialistic" legislation of Lloyd-George. One is not bound to approve every manifestation of the new life. But it is of profound importance to recognize that the wide reaching forces of an education infinitely more potent than any activities of the class-room have brought forth activities, purposes, eager and insistent quests that are already reconstructing the whole fabric of English thought and conduct. Liberty is no longer a matter of votes and institutional reforms. The negative and destructive phase, absolutely necessary and fruitful as it was, has given way progressively to a 
phase that is constructive and positive, and the English people are setting forth on voyages of discovery as adventurous and as momentous as those of Frobisher and Drake.

One element in this movement of national education for democracy is the Empire. It is not without reason that observers have said that British history in the last hundred years has been centered chiefly in two things - democracy and expansion, each unceasingly reacting on the other. And impossible as it is to discuss in any detail the infinitely difficult and complicated problems of the British Empire it is by no means impossible to indicate the most essential facts that have bearing on broad principles of policy.

The nucleus of the Empire is England. But the moment we widen our field of study to consider the Empire we find that we have to correct our terminology. To use the words England and Britain as if they were synonymous is not strictly accurate when we are referring to the last two hundred years. For England is only the most powerful and populous member of a partnership in which her three associates Wales, Scotland and Ireland - are far from being dormant or submerged. ${ }^{1}$ We say partnership, not

1 In round numbers England has a population of about $35,000,000$, Wales of about 2,000,000, Scotland of 4,700,000 and Ireland of $4,400,000$. 
federation, for the four peoples are combined in a legislative and administrative union. None of the four have separate autonomy. All send representatives on equal terms to the Parliament at Westminster, and all are subject to a common administration responsible to that Parliament. If each of the four voted en bloc on the basis of representation in proportion to population, England would naturally have an overwhelming preponderance over the other three. But this is never done. The Parliamentary divisions are based not on national affiliations but on party groupings, and if either Scotch or Irish representatives choose to vote as such they could frequently hold the balance of power.

Of the four nations thus united Ireland is overrepresented, with I03 members to Scotland's 72. But Ireland is the one discontented member of the Union, and Ireland presents accordingly the nearest and most pressing of imperial problems; she is the one member of the Empire in which there is an active and powerful movement for secession. The Irish question is of course not a new one; it has been one of the most baffling and anxious problems that England has had to face since she first began to take her empire seriously, and bit by bit she has believed that she was in a fair way to solve it. But in the last few years it has entered on a new and acute phase. In any attempt at 
imperial reconstruction Ireland's three partners - not England alone - will have to try once more to cross the abyss that separates the Irish attitude to life from the English or the Scottish and attempt to devise some workable basis on which the two islands may be peaceful and friendly neighbors. Here again it is not our province to make even a suggestion toward a solution of the puzzle. We can only state the facts that give us a starting point. And as a beginning we ask to be granted two postulates - one that England's record in Ireland up to the first quarter of the nineteenth century was consistently one of tyranny and misrule, and a second, that in recent years she has shown willingness to go to any length in the healing of the old wounds. Democratic England, in other words, has been endeavoring to cancel the misdeeds of oligarchic England.

The desires of Ireland a century ago were threefold - the removal of religious disabilities, the just settlement of a peculiarly oppressive system of land tenure, and autonomy or Home Rule. The first was granted by the Catholic Emancipation Act of 1829 and the disestablishment of the Protestant Church of Ireland in 1869. The second was dealt with in a series of Land Purchase Acts culminating in Wyndham's Act of 1903, by which the Irish tenants were aided in the purchase of their lands by payments no 
more burdensome than the old rent. Two-thirds of the Irish agriculturists now own their own land, and the Irish Land Question which provoked so much heartburning and bitterness two generations ago exists no longer. Home Rule was a more difficult matter. Gladstone's two Home Rule Bills of I886 and I893 wrecked his own power and split the Liberal Party. But at last the Bill introduced by Mr. Asquith in I9I2 and passed in I914 gave England's consent to Home Rule on the understanding that it was not to come into effect until after the war.

This condition was agreed upon because every one knew that the enactment of Home Rule by the British Parliament was far from settling the question. Six of the nine counties of Ulster were bitterly opposed to the idea of an Irish Parliament at Dublin - announced indeed that they would oppose it, so far as application to Ulster was concerned, by armed resistance. It was thought possible that some kind of federative scheme might be arranged, but the intensity of Irish sectional feeling promised so fierce a dispute over details that it seemed unwise to attempt a settlement during the war. Then long before the war closed arose a new dragon in the path - Sinn Fein. When November, 1918, brought peace, and when the triumphant but wearied Britons began to consider the fulfilment of the promise of I9I4 they found that the 
whole problem had changed its aspect. Ulster still stood on the platform of I9I2-I4. But the majority of the people who had agitated and suffered so long for Home Rule and had at last won England's support, now cast their old banners aside and demanded independence.

Part of the situation is clear; part of it is distressingly obscure. Only by an extravagant and misleading figure of speech can Ireland be pictured as in chains. She is in chains only as South Carolina and Virginia were in chains in 1860 - not so much so indeed, for the South did fear from the Union an act that was regarded as unjust, the expropriation of property and the annihilation of a valued institution. Ireland is in no danger of anything of the kind. Her champions do indeed speak of oppression and slavery, but the words have only a symbolical meaning: the oppression lies solely in the insistence on the maintenance of Union. But even if the principle of selfdetermination and the rights of small nationalities were to lead England to grant Ireland her independence-notwithstanding a danger to her national safety far graver than the danger of the NapoleonMaximilian combination in Mexico or the danger of an independent southern Confederacy ever were to the United States - there still remains U1ster. U1ster as part of an Irish republic would be an Irish 
I56 RECONSTRUCTION AND NATIONAL LIFE

Alsace-Lorraine, an Irish Poland, forced to become part of a state with which it has little in common except location on the same island. England might conceivably grant independence to Ireland. She could not possibly look on at the coercion of Ulster.

December 27, I918, saw Ireland swept by Sinn Fein. ${ }^{1}$ Seventy-two members were elected to represent Irish constituencies in the British Parliament on the understanding that they would not go to Westminster but would instead meet as the first Parliament of the Irish Republic. The astonished world has seen this carried out, has read the Irish Declaration of Independence, has heard how the proceedings were carried on not in English but in the language of the older Ireland. An Irish Parliament at Dublin demanding the withdrawal of the "British garrison"; Ulster grimly watching, rifles in hand; England waiting, wrathful and exasperated, sick of war, loathing the idea of coercion, uncertain whether the proceedings of January, I9I9, were a pageant or a tragedy; the world at large apparently disinclined to take the whole business seriously and less interested in the erratic doings of the Irish than in the growing strength of the Labor Party - such is the situation now. The conflict is

1 An interesting and sympathetic account of Sinn Fein and the movement of which it is an outcome will be found in Morris, The Celtic Dawn (Macmillan, New York, 1917). 
no doubt largely one of religion; it is at least partly economic; but it is nine-tenths based on memory and sentiment, and against these intangible but tremendous forces argument and persuasion are of little avail.

But Ireland is after all a singular and exceptional case; the future of the Empire will depend primarily on the wisdom or unwisdom shown in relation to the overseas dominions. And here we must again put forward a postulate, though in truth it is a simple historical fact rather than a postulate. It is this, that the British Empire was in no sense the result of a clearly understood imperial policy. It was not planned by statesmen and was neither acquired nor at any time governed according to a consistent theory or method. Canada was conquered as a result of an apparently irreconcilable conflict between two rivals in North America, one feudal in form, absolutist and militarist in spirit, the other free, highly individualistic, restless and intolerant of restraint. It was a rivalry of two peoples, not of kings or governments, and the victors were not thinking so much of empire as of the right to live and grow in their own way. Australia was discovered almost by accident, colonized as a penal settlement, and raised to its present status as a Commonwealth by colonists who went to the south Pacific of their own will, seeking a home and a 
larger opportunity than was open to them in the British islands. India was conquered by the East India Company, not by England, slowly, reluctantly, against specific orders from the Directors at home, as a police measure; and the Indian princes who were conquered were themselves foreign invaders ruling a subject people by the power of the sword. Princes and traders represented principles of ethics and life that could not possibly exist side by side. The conquest of India was not foreseen and not designed; it was simply one of the irrepressible conflicts of history. And these illustrations are quite typical. The Empire grew; it was not constructed. Or if it was in a sense constructed the builders were traders, missionaries, adventurers, home seekers, not - for the most part statesmen or soldiers. An imperialist policy arose only after the Empire was already a fact. ${ }^{1}$

But this spontaneous, unplanned growth of the British Empire led to a singular failure to develop any consistent policy of control. The measures adopted to meet a situation in one part of the world might be exactly opposite in principle to a measure applied somewhere else. No British statesman, except perhaps Chatham, ever seriously viewed the Empire as a whole or systematically considered either further

${ }^{1}$ See Lavell and Payne, Imperial England (Macmillan, New York, 1918). 
conquests or the organization of dominions already conquered. Each problem was met as it arose by the men on the spot, sanctioned or canceled after the fact by the administration at home, never faced as part of a whole. If we may be permitted a paradox, it came to be almost a policy to have no policy, but to adopt without formulation an ideal, the ideal of British liberty, the practical freedom that respects the freedom of others. So that the Empire, conquered without plan, remained heterogeneous in character and government. And therein lay its salvation. The myriad peoples under the British flag were never squeezed into a British mold, never made to conform to the British pattern, except in one regard: they must not kill or otherwise interfere with others, and they must be reasonably honest. They could agitate, complain, criticize, say or print all kinds of sedition, but they must keep the law.

The result was a startling one. Instead of a coherent and efficient imperial administration there was born in the British dominions a real spirit of imperial nationality. Every colonist, every subject who really thought at all, began in the second half of the nineteenth century to realize that he was part of a living thing, of a nation unorganized and formless but a nation nevertheless. Some of the colonies had been granted self-government, were practically independent, 
retaining the British flag and the British name with willing affection and pride but with no sense of subjection. They kept the phrase "British subject" from old habit; but no king or statesman of the mother country dreamed of making the Canadian or the Australian a subject in actual fact. The peoples of India, on the other hand, were really subject to the British Parliament. But this status came to be regarded as a temporary concession to difficult and complicated facts, not as anything permanent or inevitable. Every effort indeed was put forth to educate Bengalese and Rajputs, Sikhs and Mohammedans in habits of political thinking, political self-restraint, and political initiative. There might be disagreement as to immediate concessions and as to this or that procedure; Hindus and English might not see eye to eye as to the granting of autonomy this year or next; but the whole policy of Britain's rule in India loses sense and coherence if that rule is to be regarded as a fixed and absolute thing.

Once more comes in the English refusal to pay much attention to rigid general principles, even those of democracy and self-determination. The Briton knows that government is a difficult matter and a very. practical one. He gained his own liberty in a thousand years of training; he values it and is willing to help others to attain it; but 'if he sees disaster as a 
likely result of freedom he makes up his mind that whether he can work out a logical justification or not freedom must temporarily give way to safety. It is not a question of sacrifice of principles. It is a question of good sense. If we were to sum up England's attitude to even the noblest and truest generalizations about things human and social it would be something like this : that human nature is too complex and variable to be reduced to a formula or an exact science, that the statesman like the sailor has frequently to pursue a devious course to avoid shoals, and that to shipwreck the state by heading rigidly and consistently toward your goal is poor seamanship. Treason to an ideal does not lie in a temporary change of course but in a change that is permanent and conscious. And it is the Empire's confidence in Britain's fundamental loyalty to freedom and fair play that must account for the astonishing solidarity of 1914-8.

Take India, for example. Here is a land of $\mathrm{r}, 800,-$ ooo square miles and 300,000,000 people, varying in intellectual and spiritual power from Rabindranath Tagore to' Gonds and Pathans on the cultural level of the Zulu. ' In her varieties of race, of religion, of tradition India is not a nation but a continent whose peoples are less a unit than the peoples of Europe. Bengalees, Sikhs, Mohammedans and Bhils are infinitely less alike than Serbs, Portuguese, Bavarians and Gas- 
cons. Until the British conquest they had never known the smallest degree of political freedom or more than an external and deceptive unity. To have kept them disunited and permanently subject by the methods of Moguls and Sultans would have been a simple matter. But instead of doing this or even attempting it the English have founded schools and universities, have encouraged the establishment of a vernacular press, have given the cities self-government, have admitted natives to high places in the civil and military service, have organized representative Councils for the separate provinces and for the Empire, have in every way sought to awaken that which the despot does all in his power to suppress - the intelligence and initiative of the people. Mistakes have been made. Tyrannical and repressive acts have been committed by ignorant or narrow-minded Parliaments and officials. But these do not in the least obscure the essential fact that England has been fundamentally true to the ideals and principles clarified and worked out in the home island from the days of Northumbria and Wessex to the days of Gladstone and Lloyd-George. And the result has been the growth of what is externally the strangest kind of patriotism that the world has ever seen, not based on community of race or language or culture but on community of sentiment and aim. 
The problems of reconstruction so far as liberty and the Empire are concerned do not involve, then, any important change of goal or of general method. They are largely a matter of external form, the removal of inconsistencies, ${ }^{1}$ the improvement of legal and administrative machinery, the devising of some method by which the overseas dominions may be given a voice in imperial concerns. The time is even in sight when Britain will have to consider the matter of social and economic reconstruction from the point of view laid down in the platform of the Labor Party: " to insure the most equitable distribution of the nation's wealth that may be possible, on the basis of the common ownership of land and capital and the democratic control of all the activities of society." But whatever may be the outcome, and however the immediate problems may be settled the basis of reconstruction is clear. It lies not in a formula, a law or an institution but in a record. British liberty may take new forms, as it has in the past, but it cannot be destroyed, for it is interwoven in the very fiber of the British people. It may be inconsistent in its application and may wander from the path, for it is not an absolute or invariable thing,

${ }^{1}$ It need hardly be pointed out that these are innumerable. Many of them are comparatively unimportant, but some - such as what is left of the old secret and not too scrupulous diplomacy - must naturally hamper the free expression of national life in its government. 
I64 RECONSTRUCTION AND NATIONAL LIFE

but it cannot wander far or forever. And the Empire, whatever outward forms it may take, is irrevocably a living federation of free peoples. Reconstruction may give liberty and the Empire more coherent and adequate form. But that form must not too tightly enclose the life that it expresses or it will follow divine right and the Whig oligarchy into the scrap heap of discarded machinery. 


\section{The New Idealism in England}

To the average American England is the conservative, stubborn John Bull, admirable in a certain inflexible doggedness, not so admirable in the matters of stiffness, unyielding prejudices, insularity and arrogance. Even those who know the poetry of Shelley and Keats, or the paintings of Turner and BurneJones frequently and perhaps unconsciously take as their normal type of Englishman the well-fed person of florid countenance, bull-dog jaw and truculent expression with whom the cartoonists of many generations have made us familiar. Associated with this individual in the American mind there is an unpleasant memory of George III and Lord North, and of hostile gestures during the Civil War. And the whole combination has kept alive in many minds a feeling that has ceased, indeed, to be unfriendly but is hardly one of active affection. Since the early years of the war a warmer feeling has been noticeable, inspired both by admiration and by recognition that England's traditional tenacity was in this case at least a real bul- 
wark of civilization. But the change, one fears, while welcome and of incalculable value for the future, is rather emotional than rational, and curiously enough England is still to Americans at once the best known and the least understood of all the states of Europe. The English people are still under the shadow of the John Bull cartoons and the memory of unhappy episodes of the past.

The quality of tenacity, the " courage never to submit or yield," the quality that has made the bull-dog a much more appropriate symbol of the English race than the lion, is indeed recognizable as English, and tenacity in its less attractive aspects does no doubt tend to become obstinacy. But the typical Englishman, tenacious and even obstinate as he may be, is certainly not a John Bull. John Bull was, in fact, the Tory squire of a hundred years ago, a picturesque and compelling figure, indeed, of no small power in past politics, but in no sense representative of all Englishmen. If, however, instead of limiting our view to one class, we try to see whether we can venture on any general proposition regarding the English people, we might perhaps dare to say this - that the English are singularly practical in both a good and a bad sense, excelling in the cool, sensible and fearless meeting of problems as they come, but not largely gifted with foresight and imagination, content to face an immedi- 
ate difficulty and to solve it with great patience and thoroughness, but little inclined to theorize, to look beyond a concrete situation to principles and ideals. This practical tendency - in which Americans are, after all, very like their kinsmen overseas - has its unfortunate side, and has often degenerated into materialism. It is in this regard that the Saxon is often contrasted with the Celt, and the Welsh, Scottish and Irish elements pointed to as redeeming strains in the British stock. Yet even of the English themselves our statement can be made only with reservations. It may be questioned whether the hard-headed, somewhat cold-hearted, brutally practical Englishman was ever a universal type; there were always Chaucers, Shakesperes, Miltons, Lambs and Cowpers; and time and again the English imperviousnes to ideas and ideals has been broken by the surging of noble enthusiasms and of imaginative power. All we can admit is a tendency, a tendency sometimes strongly marked and sometimes hardly visible - a tendency to which Matthew Arnold gave the name of Philistinism, the opposite of idealism. This much is probably true, that Philistinism has been in the past - in spite of brilliant exceptions - the outstanding national fault of England, a sort of spiritual bondage to the practical.

Now it is precisely this bondage that has been gradually broken during the last century and a half. Eng- 
land has passed through a spiritual revolution. It is true that in most of the essentials of character and attitude to life the English of the present are still the English of Cromwell's day or of Shakespere's. The love of action and the virtues of action that made England's greatest poet a dramatist, the shrewd caution that requires progress to go by one step at a time - with tangible evidence that the new foothold is solid - the patience in untying troublesome knots and the common-sense in cutting knots that refuse to be untied, the dislike of extremes and the love of compromise, all of these characteristics run through century after century of English history. They are still present, and they show no signs of disappearing. But to them has been added a new idealism ${ }^{1}$ that has widened the Englishman's horizon and deepened his insight. The old complacent arrogance, the old insularity are visibly fading away. And this change is perhaps a more enthralling and significant phase of modern English history than even the creation of the empire or the achievement of democracy, closely associated as these all are. It has been wonderfully evident during the war, and it must be given full weight in our estimate of England's part in reconstruction.

${ }^{1}$ See pp. 72-3. By idealism in relation to England is meant simply willingness and power to look beyond the concrete present, to see in life spiritual realities as well as material things. 
Let us be specific, for the story of this spiritual change is just as definite, just as clearly marked in its incidents, as the story of a war or of a political revolution. Look first at the field most accessible and in some ways most conclusive - the field of literature. Every student of English poetry knows the characteristics of, say, Dryden and Pope. One finds in them penetrating knowledge of human nature, keen good sense, a wonderful gift of clear, vivid, striking, often epigrammatic expression, and a sounding, immediately apprehended rhythm - a music of verse as easily caught as the music of Sousa's marches. Their defect is in depth and breadth of vision, in the quality and power of the music. They are hard, external, unemotional, lacking in prophetic insight. All in them except their music could be expressed in prose, and their music - effective as it often is - rarely lifts our souls much above the prosaic, practical contemplation of the world around us.

Now turn from, say, Pope's Essay on Man to Shelley's Ode to a Skylark or to any of the lyrics of Keats. Pope and Shelley are separated in time by only a hundred years. Yet they belong to different worlds. Shelley is not concerned at all with the concrete world around him. He resents it and seeks to escape from it. Practical common sense is to him the common sense of crawling when God has given us wings, gaz- 
ing at the earth beneath when the glories of Heaven are displayed above us, shutting ourselves up in a cell and busying ourselves with its walls and bars and unlovely furniture when outside we may revel in divine beauty and the immeasurable joy of spiritual freedom. He chafes against human limitations. Life is to him not a practical thing but a sad thing because it is so - full of chains and blindness. So he is a poet not of shrewd common-sense but of revolt, of escape, of infinite yearning for a life freed from the sordid, prosaic, every-day concreteness of a practical but weary and unprofitable world. And his verse has a magic and power in its music that Pope never dreamed of; to compare Pope and Shelley is like comparing Strauss with Beethoven.

In other words the contrast between Pope and Shelley is the contrast between the self-satisfied, sensible man of the world and the man who has discovered that the gates of Heaven are before us, ready to open when we have the courage and the strength to utter the "Open Sesame" that will reveal to us the dazzling light and beauty of eternal truth. In a famous parable of twenty-three centuries ago Plato compared himself and his fellows to men living in a cavern, who knew nothing of the outer world except through shadows cast on the wall, who had never seen the sun and were content with the dim light of their cave. Let 
one of them be taken out into the splendor of daylight - he will be dazzled and blinded, anxious to flee back into the comfortable darkness. To these cave-men common-sense means living comfortably in their twilight, discussing their shadows, talking about the walls and the roof and one another, pouring scorn on the dreamers who talk of possible sunlight, space and beauty outside. Now Pope and the English people of his time were sensible, practical, capable men of the cavern: Shelley had caught a glimpse of the light and glory beyond the entrance. He did not quite know how to escape or what to do when he did escape. But he was quite sure that the life of the cave was a contemptible affair, and that to leave it - even by breaking down the walls - was the first duty of man.

And Shelley was not the only prophet of the new idealism in literature. Long before his time one may see in English poetry a new motive, the same in' essence as was expressed so powerfully by the whole " back to nature" movement in France. Among both peoples there was arising a feeling that life had become too - hard, too complex and artificial, that civilization was becoming a curse rather than a blessing, and that the cure for human ills was in a return to nature, to the simple life. In its political and social aspects the new idea was expressed in the American Declaration of Independence: "all men are created equal and are en- 
dowed by the Creator with certain inalienable rights"; and on this side the movement was a protest against the irrational tyrannies and social inequalities of the eighteenth century. Fifteen years before the Declaration of Independence it had found powerful expression in the Social Contract and the Emile, and in time to come it was to sweep over Europe in the war-cry of liberty, equality and fraternity. But in England the revolt against artificiality and the praise of nature had little influence on politics. It did indeed touch economics, and Adam Smith's Wealth of Nations ( 1776 ) was a powerful presentation of the principle of economic freedom, the first shot in the campaign that ultimately led England to abolish commercial and industrial restrictions and adopt free trade. But if the new faith in nature did not find expression in government it did influence most powerfully the thought and feelings of the people. One may see it stirring in Cowper's Task and in Thomson's Seasons. And finally it found its prophet in Wordsworth. We shall not comment on Wordsworth's religion of nature because it can be understood best if we read his poetry. But if we give a single hour to the Lines written above Tintern Abbey we may see how the door of the Engr lish mind was being opened to a new world of truth and beauty. ${ }^{1}$ Shelley was a poet of revolt and yearn-

1 The student who wishes to know more of Wordsworth is 
ing; but Wordsworth was a poet of discovery; his Heaven was found all around him, God's universe.

This note of rebellion against artificialism and of nature worship was only one sign of the change that was coming over England. The eighteenth century saw the birth of English painting. And it began in a characteristic way with the brutal realism of David Hogarth. Before Hogarth there were no English painters, and when foreign artists came to England Holbein and Van Dyck, for instance - the only works that the islanders wanted of them were portraits. Portraits one could understand; they were intelligible and altogether worth while. But all of the really great portraits of sixteenth and seventeenth century Englishmen were painted by foreigners, and in no other kind of art was there any appreciable interest. Hogarth inaugurated a new era. His paintings and engravings represented ordinary life, usually on its sordid and brutal side, and they were done with a marvelous power and vividness. In him art and the English mind met on common ground. Religious or fanciful paintings such as had expressed the genius of Florence and Venice would have left eighteenth century England cold and unresponsive. But these pictures of recommended to turn not to his complete works but to Matthew Arnold's Selections from Wordsworth (Macmillan, Golden 'Treasury Series) prefaced by his immortal essay on the poet. 
London streets, these presentations of ordinary London life, were a different matter, and suddenly the English soul awoke to the wonder and the power of painting. The ice was broken, and before the end of the century Reynolds, Romney and Gainsborough were building a noble superstructure on the foundation laid by Hogarth.

Even these painters do not show the unmistakable character of the English awakening to beauty and truth in art as do those who followed them. One who still thinks of the English character as hard, material and practical should study the landscapes of Constable and Turner, the fairy world of Edward Burne-Jones, the noble symbolism of George Frederick Watts. And when he does this he will see that the painters were revealing on canvas the same new and fascinating vision that Wordsworth, Coleridge, Shelley and Keats were revealing in poetry. That is to say the spiritual life of the English people was undergoing a slow but mighty change of which poets and painters alike were the prophets.

Moreover the appearance of a new sense for beauty was paralleled by an ethical and religious awakening that was only another side of the same spiritual transformation. In 1738 John Wesley was "converted" in a Moravian meeting in London. "It is scarcely an exaggeration," says W. E. H. Lecky, " to say that 
the scene which took place at that humble meeting in Aldersgate Street forms an epoch in English history." At once he began with the aid of his brother Charles and his friend George Whitfield the revival of religion that swept over England with amazing speed and power, a revival as fervent as Puritanism but infinitely more gentle, more spiritual, more penetrated with the spirit of Christ. And at least two of Wesley's contemporaries achieved works that embodied the faith preached by the Methodist apostles,- John Howard, the pioneer of prison reform, and William Wilberforce, the first great crusader against slavery. Wilberforce lived to see the abolition of the slave trade in 1807 , Howard to see at least the first steps taken toward the relief of the unhappy prisoners of English jails. The wave of social progress moves slowly when it meets the stubborn barrier of political conservatism and of privilege, but the anti-slavery and prison reform movements of the nineteenth century were the direct outcome of the work of these two men. The new altruism extended not only to slaves and convicts but to the degraded and ignorant of other lands and to animals. Between I792 and I8I3 were founded the Baptist Missionary Society, the London Missionary Society, the Church Missionary Society and the Wesleyan Methodist Missionary Society; thousands of devoted men went forth to carry a message of light and 
redemption to the darkest corners of Africa, Asia and the South Seas; and the whole spirit of the Rime of the Ancient Mariner was a prophecy of the movement that took visible form in 1824 in the Society for the Prevention of Cruelty to Animals.

It was in the second quarter of the nineteenth century that the changed attitude of England became most clearly and positively embodied in outward acts. The most notable of these were no doubt the removal of religious disabilities in $1828-9$, the abolition of slavery, the laws designed to protect women and children from cruel and destructive factory conditions, the removal of restrictions on labor combinations, the reform of the criminal laws, the repeal of the corn laws, and the concession of autonomy to the colonies. And this slow but clearly marked progress in the effort to relieve suffering, to remedy abuses, to remove laws, institutions and practices that involved injustice was accompanied by the appearance of a group of men who gave voice to the new aspirations, powerful preachers of social righteousness like Carlyle, Ruskin and William Morris, like Tennyson, Browning and Matthew Arnold.

There is no better single illustration of the new idealism in English thought than the Sartor Resartus of Carlyle. It appeared in 1831 and was received with derision by British Philistinism. Its apparently inten- 
tional incoherence, its frequent lapses into an impossible jargon, its grotesqueness of plan and expression laid it open to limitless ridicule. Yet it was an educative influence in Victorian England that is beyond estimate. Its whole point is the assertion that the things we see and touch are only garments, half revealing and half concealing the essential realities. Clothes, customs, creeds, institutions, governments, words themselves, forms of all kinds, are of value only so far as they express spiritual fact. The world itself is but the garment of God. Our human weakness forces us to use forms, and the forms then acquire a certain sacredness that chokes and hinders the life that created them. So that all progress consists in the making and breaking of conventions and institutions. We must make them or our life remains chaotic and formless; we must break them or they become deadening shells and barriers; and our only salvation throughout lies in seeing the form as form, the shell as a shell - never confusing the appearance with the reality.

This thesis is stated in general terms, then applied to individual life, then applied to society. With all its grotesque oddities of language it was the most brilliant and powerful social sermon of the age. The outworn creeds and conventions that still tried to pose as necessities to law, order, religion and respectability were faced and swept aside in the Ever- 
lasting Nay. The truths that were emerging from the conventional shell, the "eternal verities" were exalted in the Everlasting Yea. Falsehood and shams were denounced as eloquently as truth and reality were asserted. And long after the death of the Scottish seer himself tens of thousands of the younger men of England and the Empire took new heart and glowed with new enthusiasm as they seized the truth in the quaint gospel of Clothes.

Ruskin and Morris served in the same way as the interpreters of beauty and labor. Beauty to Ruskin was no longer grace and symmetry alone but the perfect embodiment of truth and sincerity. The Modern Painters, the Seven Lamps of Architecture, the chapter "On the True Nature of Gothic" in Stones of Venice laid down a standard for art that was in its own way as fundamental as the French Revolution in the field of politics or the Wealth of Nations in the field of economics. Art that was merely superficial, art for art's sake, art that represented what was untrue, insincere, sensual or trifling, Ruskin condemned as he would have condemned the same things in literature or in character; false painting was a lie as truly as false words, - for both were an expression of the human soul. So as Carlyle looked beyond the convention, the institution or the creed to the essential and living spirit that gave them their value, Ruskin re-interpreted beauty in terms 
of humanity and life. And he took the same standard for all products of labor and for labor itself.

The gospel that Ruskin preached William Morris endeavored to practice. Both believed that ugliness in a building or any work of human hands was the expression of evil. So Morris, seeing ugliness everywhere about him, saw behind the ugliness the English soul cramped and misled, working in darkness and degradation, needing to be redeemed not alone by political freedom but by beauty - the beauty that was defined as the expression of man's joy in good work, not to be attained unless the work was good and the laborer happy in it. This teaching Morris tried to make clear and drive home by putting it into practice, by setting on foot a reform in the whole outward aspect of English life - architecture, painting, furniture, wall paper, textiles for household use and for clothing, and city streets. And the movement which had already found expression in the growth of landscape architecture was joined to an immense if slow-moving effort to banish ugliness, to relieve the sordidness that came from ignorance and economic pressure, to make work a joy rather than a curse, and to extend the enthusiasm for beauty, sincerity, spiritual and social health to all strata of society. It is impossible to estimate the range and power of the result. The goal has not been reached; the pursuit of beauty is as unending as the 
pursuit of truth; but the impetus given by Ruskin and Morris never died away. The new social gospel found innumerable disciples whose work may be seen in countless cities, houses, factories and parks all over the world. Art has increasingly become not the luxury of a class but a possession of the whole people.

In short, the last century has seen a new spiritual birth of the English-speaking peoples. The movement for democracy has become far more than a movement for placing the sovereign power of the commonwealth in the hands of the masses. It has broadened into an effort not only to free the people from the domination of a monarch or a class but to break the chains of ignorance, of ugliness, of falsehood, of cruelty and of passion. The political struggles of the past have become the economic struggles of the present, and economic freedom is joined to spiritual freedom. The chains of the spirit are harder to break than the chains of feudalism or of absolutism, and the process is a long one because prejudices are hard to break, knowledge is hard to acquire, and it is not easy to see the way to adjust industrial and political conditions to the new ideal. But emancipation is going on nevertheless.

England's problem of reconstruction is therefore not a new one: it is the same problem that faced her before the war, and the war has been only an exhausting and tragic but stimulating and even ennobling episode in 
the long struggle toward complete social freedom, toward the revision of her forms and institutions so that they may better embody the ideals of social and spiritual health. The student who wishes to see the full force of the reconstructing effort may find it in the platform adopted by the Labor Party, in the last Education Bill, in the Ruskin University, and in every speech of Mr. Lloyd-George - not studied separately but in relation to one another. We shall not live to see the reconstruction completed; England moves slowly; but she does move, with her ancient caution but with her ancient tenacity, making sure of her foothold before taking each step but still advancing with more courage and vision than of old because the goal is more clearly in sight and because the obstacles are being one by one cleared away. 


\section{AFTERWORD}

\section{Nationalism aNd INTERNATIONALISM}

RECONSTRUCtion is then fundamentally the progressive effort to put into form the changing life of society. But the word is used more specifically to express something a little narrower than this. In appearance at any rate human progress is not an even flow, a placid evolution, but a series of explosions alternating with periods of comparative quiet, and no doubt it is the painful and difficult effort to replace the forms broken or disturbed by the explosions that has suggested the metaphor implied in the word reconstruction. With such an interpretation we have no quarrel. For it is of course true that a great crisis or shock involving a radical change in the social outlook, whether it comes as a paralyzing disaster or as an invigorating stimulus, will naturally involve peculiarly difficult problems of readjustment. The collapse of the Roman Empire in the west, the French Revolution, the Great War are shocks of this kind, and in the study of history they are the dramatic episodes, the ends and the beginnings of eras, each accompanied and followed 
by a radical rearrangement of social perspective and a large degree of external change.

But the crash seldom comes unheralded, nor is it different in kind from the less spectacular crises of every day. The laws of change and growth are punctuated by wars and revolutions, perhaps, but not interrupted by them. And any permanently valid reconstruction - after no matter how great or small a crisis - is the fruit and expression of national life, not an original scheme worked out a priori in the brains of statesmen. For in human affairs as in all others it is normally true, in spite of appearances, that nature does not move in leaps, and that the spectacular character of a revolution, a victory or a defeat, hides from us but does not nullify the steady, orderly movement of social forces. A plan of reconstruction that ignores these permanent things in national life is an effort to paint the Ethiopian white, to extract the flower from the bulb. "Nature can be commanded" in short " only by being obeyed."

One aspect of the present problem is of transcendent importance. Like other aspects it is not new, even though it seems new because seen with unprecedented clearness. We have dwelt on the fact that each nation is slowly working out its own salvation, making its way toward its own goal. But profoundly necessary as it is to realize that Italy, Serbia, France, Russia and 
the rest must be considered organic units, earnestly as we may hope that nationality and state boundaries may be made to coincide so that national progress - i.e., progressive destruction of outward forms, progressive reconstruction of the nation as a living body - may go on unimpeded by deformity and disease, yet it does not follow that national self-determination must mean national isolation. Aristotle's dictum that man is a social being, that individual isolation is destructive of individualism itself, had a corollary. The isolated human being is, no doubt, a contradiction in terms. But so is the isolated social group. To separate one's country from the world is to court degeneracy and death. So that though we have been looking specifically at the national groups themselves, seeing their national life expressing itself in a never ending process of readjustment, we must as we close add the reminder that as the individual finds his individualism intensified and enriched in society, so nationalism is intensified and enriched by internationalism.

It might be inaccurate, certainly it would require careful definition of terms, to describe this as a modern discovery. But it is at least true to say that the age which has seen so tremendous a development of the principle of nationality has seen also a steady, though not uniform or consistent, development of conscious community of interest between nations. And the 
problem has been to give this a wise form that would ensure growth and permanence without hampering national freedom. So stated, the difficulty and the ideal alike were not realized until the horror of the War cleared men's eyes. But when the idea of a League emerged it was seen as a natural and even obvious culmination, not as a new device to meet a new situation.

Whether the spiritual community of nations is aided materially by the mixture of races that has been going on from time immemorial is a question. Not that any one would dispute its value. But in aiding the movement toward the breaking down of national antagonisms the "melting pot" process seems to have a very definite limit. The more thoroughly fusion takes place, obviously, the more entirely does the new nationality replace that of parents and grandparents, with no apparent lessening of such prejudices, narrowness or aggressiveness as the adopted nation may possess. We must look to things other than the mere movement of population for the building of international friendship and common understanding.

Yet there have not been lacking signs that nationality itself, with all its intensity of prejudice and frequent narrowness of patriotism, has carried with it the seeds of internationalism, seeds slow-growing but by no means barren. Again and again during the nineteenth century attempts were made to find common 
principles on which all western peoples could agree. Of these the Geneva Convention and the Hague Conferences were only the most notable. Even the meetings of diplomats and statesmen, even the attempts at international agreement that had least relation to the great currents of national life, such as the Congresses of Vienna and Berlin - to take the two examples most discredited now by the wrongness of their principles and the futility of their results - were signs of the times. In spite of selfish and superficial diplomacy, in spite of sadly obvious blunders and sins, even the most crudely external conferences of the last hundred years were indications of a movement of which Metternich, Disraeli and Bismarck were unconscious partakers and which had in it a mighty surge and range that never came within their vision.

And let it be remembered that it is the movement that counts, the beneficent spread and growing power of a redeeming conviction and aspiration, rather than any definite accomplishment. We cannot judge the value of the international conferences solely by their visible fruit. Nor can we regard the tentative agreements reached from time to time as worthless because of the lawlessness of the past six years. It is true that the Red Cross alone would justify the Geneva Convention, that the International Tribunal alone would justify the Conferences of I899 and 1907. But 
in society as in the individual the definite, tangible act is only an infinitesimal part of the total life current, the part that comes to the surface and may be submerged again in the tempest of war. Visible signs of progress, welcome as they are, are after all most welcome as symbols of the forces that produced them, and there are enough of them to point the line of advance. For the age of conventions and conferences toward the finding of common principles was the age also of arbitrations, of the rapid building of a still tentative but nevertheless impressive system of international law, and of the clearing away of international differences by friendly negotiation. The single fact of the unarmed frontier between Canada and the United States, of the century long validity of the agreement of $18 \mathrm{I} 7$ for disarmament on the Great Lakes, has a significance that is not easily measured.

It is well to remember too that movements quite outside of formal politics, efforts to solve problems common to all nations through religious, scientific and social coöperation, have a far from unimportant part in the same progress. Thus the earnest and even passionate advocacy of radical schemes of social reconstruction has led to world wide organizations for the attainment both of durable peace and of universal justice based on liberty. Many of us believe that the plans and ideals of the Socialists are full of flaws, 
perhaps even fundamentally wrong. But their specific platforms and doctrines are from our present point of view matters of indifference. They may embody truths, fallacies, or bewildering mixtures of true and false. But in any case they represent just as real an effort to meet a problem that is international and universal as a congress of scientists or an ecumenical synod.

Nor should we condemn Socialism for its failures any more than for questionable doctrines. The frequent criticisms of socialist internationalism that are based on the participation of German socialists in the war are hardly just. No matter how keenly an individual may feel his individualism to be dependent on society there must come times when he will find it necessary to put himself in opposition to this or that form of society and become a rebel. Equally is it true that one may be a sincere believer in international socialism and yet bow to an emergency and join his country in armed conflict with others, even when he is far from sure that in that particular war his country is guiltless. Society, we repeat, does not exclude individualism, nor does internationalism exclude nationalism. In an ideal state, an ideal world, there would be no such conflict of interests and ideals. But too often in human affairs right and wrong are so intermingled and hard to discern that the individual, in ignorance and puzzle- 
ment, has to drift with the tide or make a judgment that he knows is fallible. His deepest convictions may even be swept aside by the powerful forces of passion and prejudice, as a man struggling with temptation may fall time and again in the battle and yet win through to victory. So the weakness of the flesh, the power of tradition and "mob psychology" must not lead us to scorn of the ideal or too much skepticism as to ultimate achievement. Socialists have been inconsistent; some of them have proved false to their principles; but the miracle of universal consistency is not to be demanded as a test of value. It would be hard to deduce from the sins of Christians the futility of the New Testament.

Our conclusion then is clear. Making all allowances for blunders and sins, remembering that social and political progress is inevitably slow, that even the best human ideals are obscured by ignorance, weakness and blindness, there is yet discernible in every nation of Europe a movement toward liberty, justice, courage in the search for truth, and altruism, toward a reconstruction that will more adequately embody the human yearning for peace, coöperation, kindliness and equal opportunity. Each people faces the problem with a temperament, an age-long education, an environment, a social structure that are in great measure peculiar to itself. And so deep-seated are these national 
peculiarities that no German may safely dictate to a Frenchman, no Englishman may safely dictate to a Russian, what should be the next step forward.

Yet if each nation must face its own problems of reconstruction, building on foundations laid in past centuries, we may still welcome the signs that common grounds of universal humanity are being slowly discovered, and that international sympathy bids fair to replace international antagonism. The League of Nations is only the most recent step in a noble series. It is just as truly related to preceding efforts as each forward movement of the nations in their solution of individual problems of politics and industry. It is just as truly a product of national growth as the democratic state is the product of the individuals composing it. And we need by no means regard it as final, or scorn it if it should prove imperfect. All that we should ask is that it may take us a little nearer to the light, a little farther from the darkness of the cavern. 


\section{INDEX}

Alexander II, Czar of Russia, 96, II6-117

Alsace-Lorraine, 6, 7, I5

Anarchism in France, 49-50; in

Russia, III-I12, I3I-I32

Arnold, Matthew, 150, 167

Australia, 10, 157

Austria-Hungary, 5, 8, II

Bakunin, Michael, 107-108

Balkans, I5

Belgium, I5

Berlin, Congress of, 186

Bessarabia, 7

Bismarck, 57

Blanc, Louis, 46-47

Bolsheviki, 134-137

Bosnia, 7

Breshkovsky, Catherine, I2I

Britain, 5, 6, 7; reconstruction in, $163-164$

British Empire, 9-10, 15I-162

Bulgaria, 7

Canada, 157

Capitalism, 12, 86

Carlyle, Thomas, $176-78$

Carta, Magna, I44-I45

Cezanne, 44-45

Collectivism, 48

Commons, House of, I44-147

Communism, 87

Constantinople, 0

Danton, 38-39

Decembrists, II5-II6

Democracy, $1-3,7-9$

Denmark, 6

Diderot, 38

Dostoyevsky, 98, ror

Douma, Imperial, I14, 127, 128;

local, I16, 127

Emile of Rousseau, 26-28

England, 7; liberties of, I42147 ; idealism in, $168-18 \mathrm{I}$; relation of with Ireland, I5I157

Expansion of Europe, I-3, 9-12

Factory system, 12

France, 5, 7, 9, 10; art in, 4246 ; education in, 38-4I

Franklin, Benjamin, I42, 146

French Revolution, 5, 14, 17-28, $3 \mathrm{I}-35,37,54$; reaction of, on Russia, 95

Geneva Convention, I86

Germany, 4, 5, 7, 8, 10, II ; characteristics of, $56-58,62-74$

Gogol, Nicolai, ror

Greece, 7

Greuze, 42-3

Hague Conferences, I 86

Hapsburgs, I5 
Hanseatic League, 62

Herzen, Alexander, 107-8

Hogarth, David, I73-4

Hohenzollerns, 15

House of Commons, 144-147

Howard, John, I75

Idealism, Platonic, 70-8r ; German, 69-73, 83; French, 72; English, 72-3, I68-181; Russian, $138-140$

Imperialism, 2, 10

India, I, 2, 158, I60-162

Industrial Revolution, I, 2, 12, 13; in Russia, 96; in France, 46

Internationalism, 184-190

Ireland, 6, 7, 152-1 57

Italy, 4, 5, 10-12

Japan, 9

John Bull, 165, 166

Kerensky, II4, II5, I33

Kropotkin, Prince, IIo, I33

Lassalle, Ferdinand, 47, 86-88

League of Nations, 185,190

Liberalism in Russia, 106, I15I16, 124-129

Luther, Martin, 62-67

Magna Carta, I44

Marx, Karl, 47, 86-88, I37

Millet, 43-44

Mir, Russian, 12r

Morris, William, I78-180

Napoleon Bonaparte, 17, 18, 28, $33,40,60,79,80$

Nationality, I-7

Nihilism, 96, 102, 103-5, I10III, II7
Pan-Germanism, I5

Pan-Slavism, I6

Parliament, British, 144-148

Peter the Great, 94

Philistinism, British, I67

Plato, idealism of, 70-71, 170I7I

Poland, 6

Pope, Alexander, 169-170

Protest of the Cour des Aides, 2I

Prussia, 6r, 62, 79-83, 85

Reformation, German, 63

Reform Bill of 1832,148

Revolution, English, 145; French, 5, 14, 17-28, 31-35, 37, 54; Russian, 15, 102-103, 106I08, II7, II8, I24

Roumania, 7

Rousseau, 18, 20, 23-28

Rudin, Dmitri, as a Russian type, 99, 100

Ruskin, John, I78-180

Russia, I, 2, 8, 9; compared with western Europe, 92-93. 98; liberation of serfs in, 96 , II6; territory ard population, II9-I 2 I

Sartor Resartus, 176-178

Schleswig, 6-7

Serbia, II

Serfs, emancipation of, 96,116 Shelley, 169-I70

Sinn Fein, 154, 156

Slavic inertia, 98, 101-102, 105 Smith's Wealth of Nations, 172 Social Contract, 14, 18, 22, 24, 26 
Socialism, 13, 187-189; in Trentino, 6

France, 46-49; in Germany, Tripoli, II

85-90; in Russia, 125, 129- Turgenev, 99, 100, 103-4, 121I39

Sorel, Georges, 5I-52

State, English and American theory of, 76-77; German theory of, 77 ; as an organism, $77-8 \mathrm{I}$; as Power, 82-84

States General, 17, 18, 20, 21

Syndicalism in France, 49-53

122

Turkey, 8

Ulster, I54-156

United States, I0, I55

Vienna, Congress of, 186

Voltaire, 20, 22-23

Watteau, 42

Terrorists in Russia, I06, II7- Wesley, John, I74-175 I 18

Wilberforce, William, I75

Tolstoy, I0I, I40

Treitschke, 82,84

Triple Alliance, II

Wordsworth, I72-I73

Zemstvos, II6 

THE following pages contain advertisements of a few of the Macmillan books on kindred subjects. 


\title{
Problems of Reconstruction
}

\author{
By ISAAC LIPPINCOTT \\ Associate Professor of Economics, \\ Washington University
}

Cloth, $12^{\circ}$

"From an industrial point of view the nations at war are confronted with two groups of problems. Stated briefly, the first group contains questions of concentrating industrial effort largely on war production, of diverting men, materials and financial resources to the essential industries and of curtailing the operations of all the rest, of regulating commerce with foreign countries, and of formulating policies and methods for the accomplishment of these ends. In short, this is principally a question of development of war control with all that this implies. The second group of problems arises out of the first. It involves such questions as the dissolution of the war organization, the removal of the machinery of control, the restoration of men, funds, and materials to the industries which serve the uses of peace, and the reëstablishment of normal commercial relations with the outside world. The latter are post-war problems. Their prompt solution is necessary because the war has turned industrial and social life into new channels, and because it will be necessary for us to restore the normal order as quickly as possible. These brief statements outline the task of this volume."

\section{THE MACMILLAN COMPANY \\ Publishers 64-66 Fifth Avenue New York}




\title{
PROF. CANBY'S NEW BOOK
}

\section{Education by Violence}

\author{
BY HENRY S. CANBY
}

Cloth, 12mo. Preparing

Professor Canby here deals with the effects of the war and the rehabilitation of society at home and in Europe. Among the specific topics taken up are the conditions in England and France, the racial and spiritual differences and agreements between the Allies and the prospects of a peace which shall finally end war. As the reflections of the mind of an American scholar when he comes into contact with the realities of the war and its changes, the book is certain to have a wide interest in this country.

\section{CONTENTS}

I ON Writing the Truth

"Transport 106 "

II ON THE ENGLISH

Blood and Water

III ON IRISh Literature

The Irish Mind

IV On the Sense of Race

Innocents Abroad

V On MORALE

Spes Unica

VI ON The UnCommon MaN Tanks

VII On the Personal in Education Education by Violence

VIII ON THE NEXT WaR When Johnny Comes Marching Home

IX On Salvage and Waste War's Ending

\section{THE MACMILLAN COMPANY . \\ Publishers 64-66 Fifth Avenue New York}




\section{National Governments and the World War}

\section{By FREDERIC A. OGG}

Professor of Political Science in the University of Wisconsin

AND

\section{CHARLES A. BEARD}

Director of the Bureau of Municipal Research, New York City

Cloth, $8^{\circ}, \$ 2.50$

In this new volume Professors Ogg and Beard give us a fuller realization of the bearings of governmental organization and practice upon public well-being, a better knowledge of the political experience and problems of other peoples, and a new enthusiasm for national and international reconstruction on lines such as will conserve the dearly bought gains of the recent conflict. In dealing, as it does, mainly with a comparative exposition of political institutions, ideals and practices national and international - this work will enable us to trace their power in contributing to or detracting from human welfare.

A good part of the book undertakes to show what the heritage and genius of the principal peoples lately engaged in the World War have meant in the shaping of contemporary political institutions and ideas. The great changes wrought in governmental organization and procedure during the war are carefully described, beside pointing out clearly the major political problems that remain for settlement during the early years of peace.

\section{THE MACMILLAN COMPANY}


"Brilliant Synthesis of the World's Peace Problems"

\section{The Great Peace}

\section{BY H. H. POWERS}

Author of "America Among the Nations," "The Things Men Fight For," etc.

Cloth, I2mo, \$2.25

"What shall be the terms of the peoples' peace - the Great Peace? What are the principles of that better statecraft which has been slowly and half unconsciously taking shape in the minds of those who through the will to victory have slowly won the right to will the world's peace? And what do these principles require in the way of concrete adjustments and arrangements among the mountains and the rivers and the seas where men have chanced to be born and have snugly nested themselves in the traditions, the prejudices, the loves, and the hates of a hundred generations?" It is with such questions as these that Dr. Powers is concerned.

"The necessity for speed laid upon the author found him amply prepared by study, travel, training and practice. However hurried his task of writing, his arguments and conclusions are manifestly results of long, earnest, soberly measured and carefully digested thought. Presented in the author's graphic, comprehensive and impressive style, they constitute, in effect, a clue to the vast labyrinth through which the Versailles conference must shortly wander distraught."

"The peace conferees took a dictionary and encyclopedia along for a library. They should add Mr. Powers' book it would be helpful amid even a stock of universal knowledge." - The Philadelphia North American.

"The terms of peace to be agreed upon must be based on the fullest recognition of the special problems and wishes of the associated nations. The problem of problems is the control of the sea. . . . These questions are discussed with thoughtfulness and clarity, and a wide grasp of circumstances and difficulties." - The Detroit Free Press.

\section{THE MACMILLAN COMPANY}




\section{League of Nations. Vols. I and II}

\section{BY THEODORE MARBURG}

Each $\$ .60$

"This little book is a history of the movement in the United States to secure action by the United States and other nations, after this great world war, looking to the establishment of a League to Enforce Peace. Mr. Marburg, the author, is a student of international law, a publicist, and a diplomat of marked ability and learning. . . . Mr. Marburg, with Mr. Holt of the Independent, was the first to move for the formation of a League to Enforce Peace, and has been most diligent and effective in promoting the League ever since. . . I hope that Mr. Marburg's little book will be widely read."-Hon. William Howard Taft, in Preface.

\section{The End of the War}

\section{By WALTER E. WEYL}

Author of "American World Policies," "The New Democracy," etc.

$\$ 2.00$

"The most courageous book on politics published in America since the war began."-The Dial.

"An absorbingly interesting book . . the clearest statement yet presented of a most difficult problem."Philadelphia Ledger.

"Mr. Weyl says sobering and important things. . . . His plea is strong and clear for America to begin to estab,ish her leadership of the democratic forces of the world ... to insure that the settlement of the war is made on lines that will produce international amity everywhere." $-N . Y$. Times.

\section{THE MACMILLAN COMPANY}

\section{Publishers 64-66 Fifth Ávenue New York}






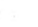


$x=\therefore<+$

、 



$\begin{array}{ll}\text { D } & \text { Lavell, Cecil Fairfield } \\ 653 & \text { Reconstruction and } \\ \text { L3 } & \text { national Iife }\end{array}$

\section{PLEASE DO NOT REMOVE \\ CARDS OR SLIPS FROM THIS POCKET}

\section{UNIVERSITY OF TORONTO LIBRARY}


8

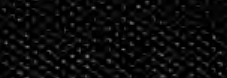

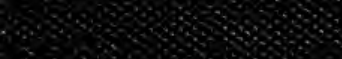

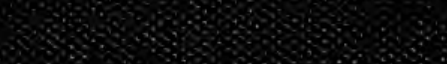

3

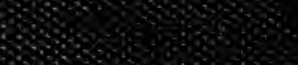

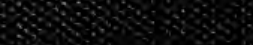

$+30 \times 3$

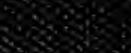

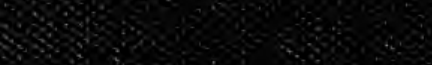

38

8

28

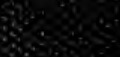

